\title{
Under Prying Eyes: Repression, \\ Surveillance and Exposure in California, 1918-1939.
}

\section{By Simon James Judkins}

\author{
A thesis submitted to the Victoria University of \\ Wellington in fulfilment of the requirements for the \\ degree of Master of Arts in History
}

\section{4.}




\section{Abstract}

This thesis is a study of a network of surveillance organisations that developed in California, especially around Los Angeles, between the First and Second World Wars, employing surveillance as a tool of political and economic repression. It argues that over the course of the period surveyed an expanding network exerted a significant conservative, antilabour influence on California's history. This was especially so at the end of the 1930s, when the network contributed information and personnel in a series of public exposures targeted at a broad range of political enemies. As part of a conservative mobilisation against the New Deal nationally and within the state, the California surveillance network created a role for its members based on an ability to smear liberal politics with the taint of communism, a role that continued after the Second World War.

For much of its history this network was fuelled by a desire to enforce a conservative status quo that protected the profits of the business community with which it allied and relied upon financially. In the immediate aftermath of the First World War this necessitated the repression of political radicals such as the International Workers of the World, Socialists, Pacifists, Bolsheviks, and other radical dissenters. As California experienced economic booms in the 1920s and crisis in the 1930s, the network attracted new collaborators to form a multifarious entity comprised of patriotic and veterans' organisations, law enforcement, military intelligence, employers' associations, and labour spies. As a result the network had access to sources from all spheres of Californian public and private life, including from within government. Mirroring the tactics of the Communist Party of the United States, which attracted its most ardent suspicions, the network also deployed undercover operatives to infiltrate and disrupt the targets of their surveillance. The information exchange that took place between members of the network facilitated the creation of vast archives to hold all the collected material, which contained data on Californian citizens of all political persuasions.

The passage of New Deal labour legislation in the mid-1930s presaged a shift in the network's activities. After the National Industrial Recovery Act of 1933 and the National Labor Relations Act of 1935 aided union organisation, the California surveillance network increasingly 
became involved in the surveillance and repression of labour movements. Fear of communist infiltration of labour movements, particularly after a series of major strikes in the maritime and agricultural industries, partly explains this increasing attention. As this thesis shows, antilabour espionage was also occasionally motivated by profit, misunderstanding, intolerance, and greed.

The surveillance network contributed to the formation and activities of the Special Committee on Un-American Activities chaired by Representative Martin Dies which began in 1938. Presenting evidence acquired from its operations, it helped to create evidentiary and ideological support for the post-war anti-communist investigations which drew upon documentation and expertise created in the 1930s. The California surveillance network was thus a major foundation for what became known as McCarthyism. 


\section{Acknowledgements}

Writing this thesis has been a long and difficult task, but one thankfully relieved by the company of the fantastic stuff and students in the History programme at Victoria University of Wellington. My gratitude goes to a few specific faculty and staff who were both sources of sublime inspiration, gainful employment, or much-needed advice-and sometimes all three: Steve Behrendt, Giacomo Lichtner, Teresa Durham, Pennie Gapes, Pauline Keating, Jim McAloon, Sekhar Bandyopadhyay, and Philippa Race for her help getting over the final hurdle.

Special thanks to my longest-serving office mates: Daniel Cruden, Alexey Krichtal, Florence Baggett, Laurel Carmichael, and Matthew Vinke for their companionship, healthy cynicism, and spit-balling prowess. I'll add my poem to the wall when I return.

My most sincere and humble gratitude belongs to my supervisor and mentor: Dolores Janiewski. Dolores, there are precious few ways that I can offer my gratitude for all the time, wisdom, aid, and faith you have bestowed on me over the last four years. I hope that you find sufficient value in these pages to consider some of that time well spent.

And to my friends, family and wife: this, the most difficult thing I have ever created, is now complete. Thank you for your encouragement, your patience, your empathy, your ill-timed temptations, and your love. I will forever be grateful for everything you did to ease the burden. Lucie, you can start teaching me French now. 


\section{Table of Contents}

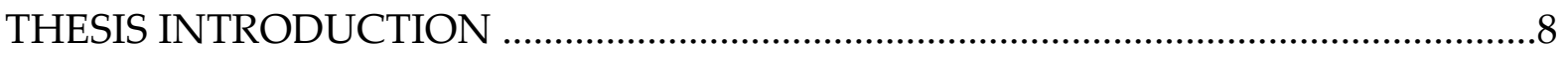

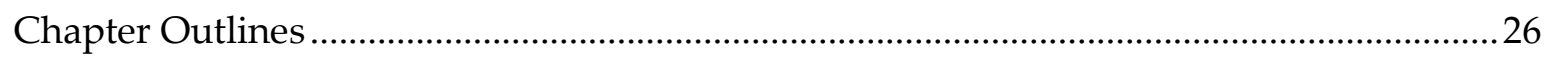

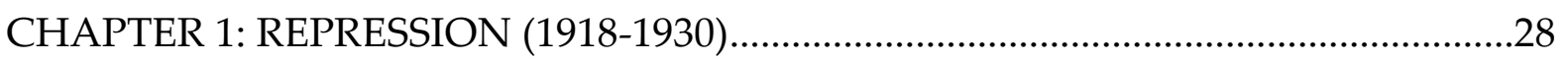

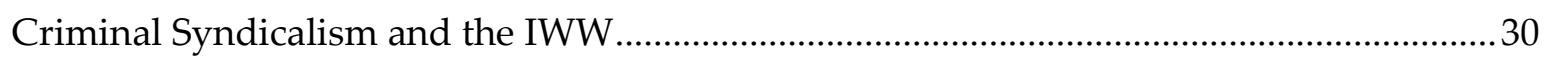

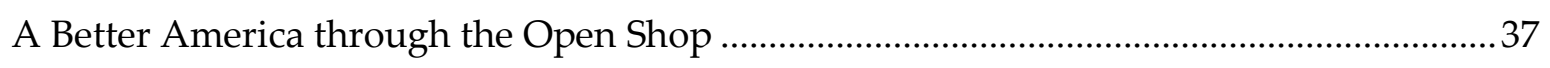

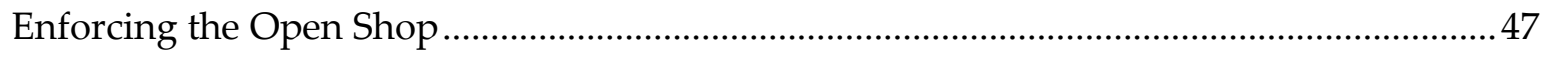

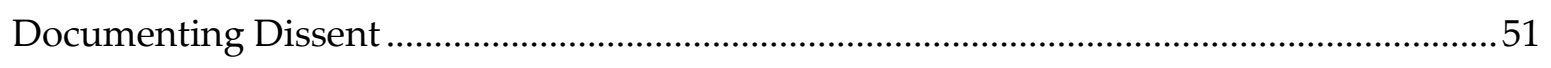

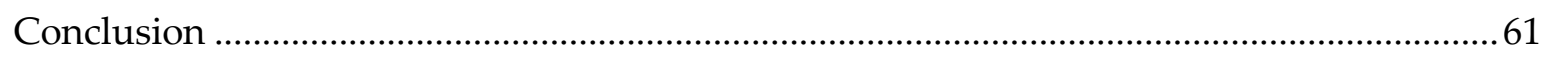

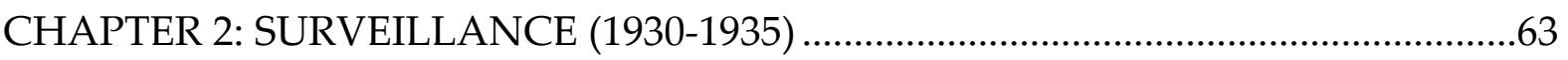

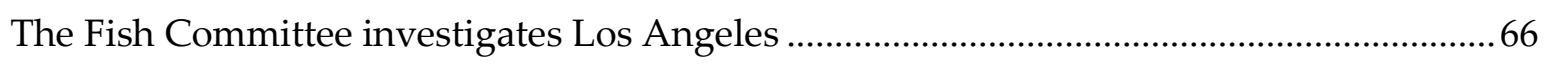

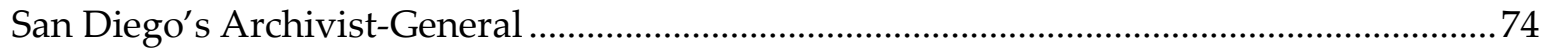

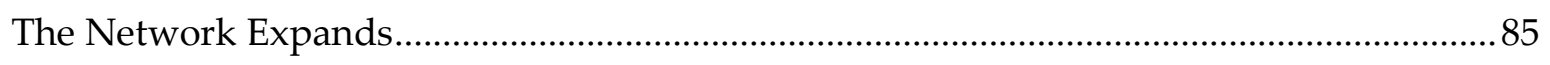

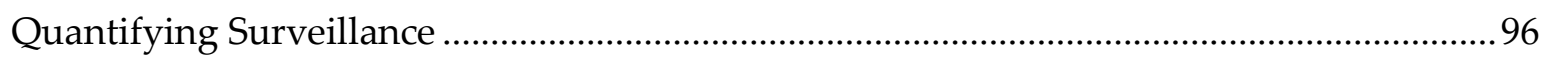

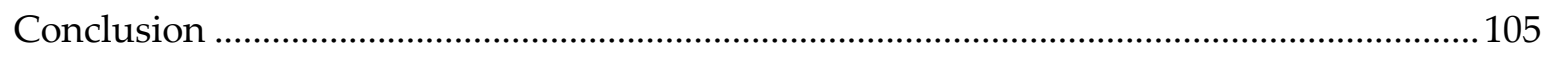

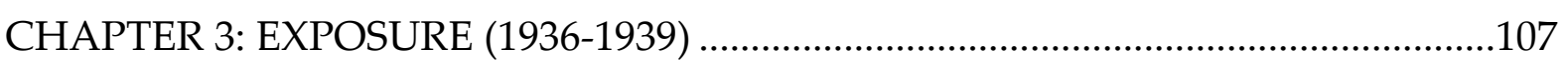

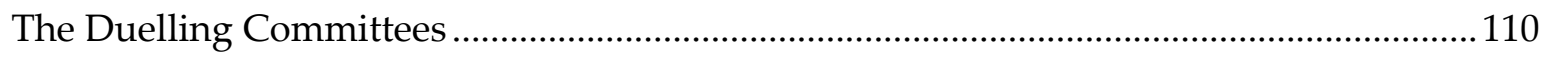

Suspicious Eyes and Expanding Targets ........................................................................... 123

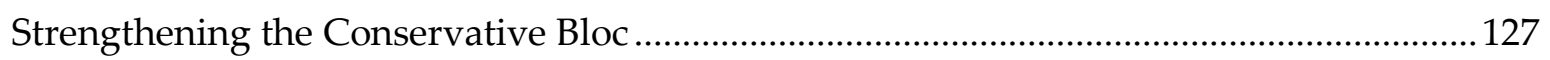

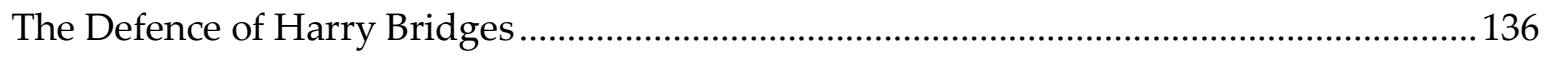

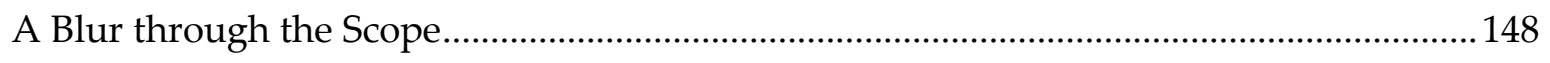

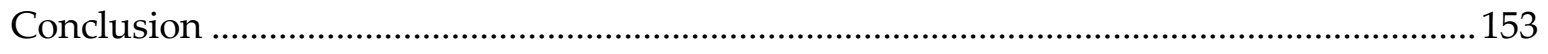

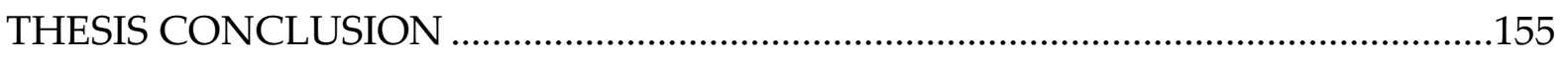

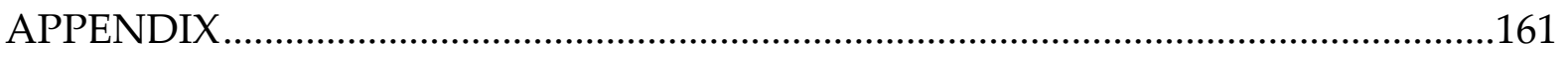

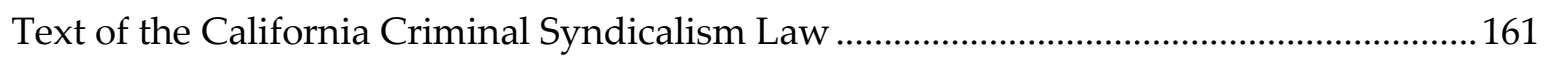

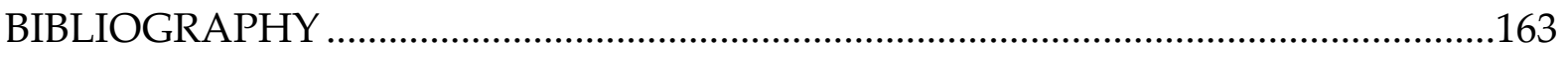

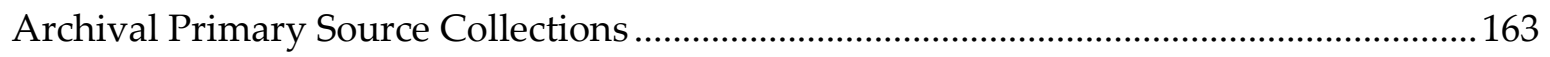

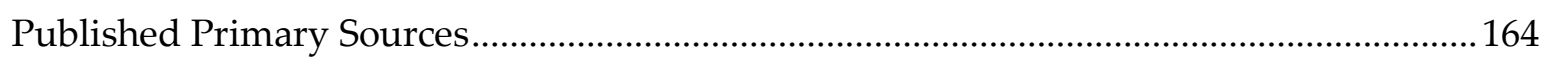

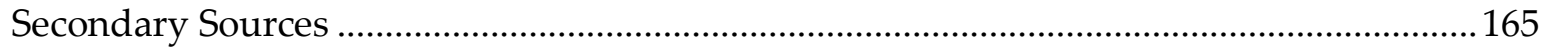




\section{Abbreviations Used}

\begin{tabular}{|c|c|}
\hline ABPS & Association for the Betterment of Public Service \\
\hline ACLU & American Civil Liberties Union \\
\hline AFC & Associated Farmers of California \\
\hline AFL & American Federation of Labor \\
\hline APL & American Protective League \\
\hline AVIF & American Vigilant Intelligence Federation \\
\hline BAF & Better America Federation of California \\
\hline BOI & California Bureau of Identification \\
\hline CAWIU & Cannery and Agricultural Workers' Industrial Union \\
\hline CFC & Commercial Federation of California \\
\hline CCD & Civic Council of Defense \\
\hline $\mathrm{CIO}$ & Committee (after 1938 Congress) of Industrial Organizations \\
\hline CP / CPUSA & Communist Party of the United States of America \\
\hline FBI & Federal Bureau of Investigation \\
\hline G-2 & The Intelligence Corps of the U.S. Army \\
\hline HUAC & $\begin{array}{l}\text { The House un-American Activities Committee. A catch-all acronym for } \\
\text { the committee's various incarnations, dating roughly from 1930-1975. }\end{array}$ \\
\hline IASF & Industrial Association of San Francisco \\
\hline ILD & International Labor Defense \\
\hline ILWU & International Longshoremen's and Warehousemen's Union \\
\hline INS & Immigration and Naturalisation Service, Department of Labor \\
\hline LAPD & Los Angeles Police Department \\
\hline LBPD & Long Beach Police Department \\
\hline MI & Military Intelligence Corps. Also known as 'G-2' \\
\hline $\mathrm{M} \& \mathrm{M}$ & The Merchants and Manufacturers Association of Los Angeles \\
\hline NIRA & National Industrial Recovery Act, passed in 1933 \\
\hline NLRA & $\begin{array}{l}\text { National Labor Relations Act, passed in 1935. Also known as the } \\
\text { Wagner Act, and a successor to NIRA }\end{array}$ \\
\hline NLRB & National Labor Relations Board \\
\hline
\end{tabular}




\begin{tabular}{|c|l|}
\hline ONI & Office of Naval Intelligence \\
\hline SCI & Southern Californians Incorporated \\
\hline SDPD & San Diego Police Department \\
\hline SFPD & San Francisco Police Department \\
\hline TUUL & Trade Union Unity League \\
\hline UAW & United Automobile Workers \\
\hline UCC & Union of California Citizens \\
\hline WMIU & Western Mechanics Industrial Union \\
\hline YWCA & Young Women's Christian Association \\
\hline
\end{tabular}

\section{List of Charts}

\begin{tabular}{|l|l|l|}
\hline Chart 2.1. & Origin of Documents in Van Deman Archive, 1932-1933 & p. 76 \\
\hline Chart 2.2. & Comparison of scope of Van Deman Archive, $1932-1933 \& 1935$ & p. 97 \\
\hline Chart 2.3. & Targets of Van Deman Archive, 1932-33 \& 1935 & p. 101 \\
\hline Chart 2.4. & Origin of Documents in Van Deman Archive, $1932-1933 \& 1935$ & p. 102 \\
\hline Chart 3.1. & Institutional focus of Van Deman archive, $1932-33,1935, \& 1937$ & p. 124 \\
\hline Chart 3.2. & Targets of Van Deman archive, $1937 \& 1939$ & p. 149 \\
\hline
\end{tabular}

A note on U.S. \& New Zealand spelling:

This thesis employs New Zealand spelling, though the U.S. spelling is retained when quoting directly or referencing organisations in order to preserve the original text or name. This may be noticed with some frequently used words such as 'labour'/'labor'. Any other inconsistencies encountered should be for the same reason. 


\section{THESIS INTRODUCTION}

In Southern California during the 1920s and 1930s a loose coalition of business, patriotic, military, and law enforcement groups formed to conduct surveillance of their political and economic enemies, and to use the information they collected for specific political and economic goals. They were very effective. This thesis explores this expanding coalition of private and public groups in the state of California between 1918 and 1939. It is particularly focused on explaining conditions in the 1930s, the most dynamic period of political and economic surveillance in and around the city of Los Angeles and its agricultural hinterland. Why study surveillance in California? One reason is because of the intensity and ubiquity of the practiceat no other point in the state's history did such a multitude of different groups participate in so much surveillance collection - while another reason is provided by the way that surveillance was wrapped up so tightly with the historical development of California during this period.

Between 1870 and 1900 Los Angeles experienced its first demographic explosion, its population growing from 5,000 inhabitants to over 100,000. ${ }^{1}$ By 1917 the city had reached a population of more than 500,000 which would double again in the 1920s as the film and petroleum industries continuously attracted new residents. The arrival of aircraft manufacturing and other heavy industries in the 1930s followed. Many of the newcomers were working class migrants who had travelled West via the Southern Pacific. Responding to the faintest signs of labour organisation, business and political elites developed and invested substantial resources in a repressive social mechanism designed to exert labour 'discipline' disrupting all attempts to organize and mobilise the city's workers, and likewise any attempts to legislate on their behalf. Businessmen, organized in an open shop alliance under the auspices of the Merchant's and Manufacturer's Association [M\&M], the Los Angeles Chamber of Commerce, and trade associations initially relied on the importation of non-union labour, the co-opting of law enforcement to intimidate workers, and the use of industrial spies. Over time

\footnotetext{
${ }^{1}$ California Department of Finance, '1850-2010 Historical US Census Populations of Counties and Incorporated Cities/Towns in California', Accessed 17/2/13 from http://www.dof.ca.gov/research/demographic/state census data center/historical census 1850-2010/view.php
} 
Los Angeles' anti-labour alliance also developed tactics of greater sophistication-most especially the interrelated processes of repression, surveillance, and exposure which this thesis investigates.

Yet California's anti-labour forces were not all-powerful, and this thesis will also explore resistance to the surveillance coalition. Attention to selected episodes of resistance helps to explain not only the reason for the surveillance coalition's existence, but also their subsequent development and evolution through the 1920s and 1930s. To some extent scrutiny and countersurveillance from their targets pushed the surveillance groups towards an increasing reliance upon undercover informants and 'front groups' in the late 1930s, as did New Deal labour legislation, the disbandment of the Los Angeles Police Department Intelligence Bureau and the elections of reformers to city and state governments. The 1937 advent of the La Follette Civil Liberties Committee also provided the opportunity to reverse the surveillers' gaze-subjecting employers' organizations to surveillance, exposure, and what they undoubtedly viewed as the repression of their ability to maintain an open shop.

Why create a private surveillance network in early $20^{\text {th }}$ century California? Unsurprisingly, the simplest answer was for financial gain. Though other reasons would emerge in response to later developments, both national and local, the first private groups engaged in political surveillance and repression in California were chiefly motivated by a desire to defend private profits from organized labour. Nowhere in California was the defence of private profit more hard fought than in early $20^{\text {th }}$ century Los Angeles, and it was largely thanks to a coalition of elite businessmen and the surveillance initiatives they sponsored or founded that capital always prevailed. These powerful civic and economic leaders saw the city blooming from the desert as a product of their personal ambition and vision, and thus a fiefdom that should be governed according to their requirements.

These origins led Carey McWilliams to write in 1946 that the growth explosion of Los Angeles was not a growth at all, that the city was instead 'conjured into existence' through the efforts of its most determined boosters, men who built fortunes on the gamble. McWilliams called the resulting influx 'the largest internal migration in the history of the American people', and significantly for real estate owners and city planners, the 'first migration of the automobile 
age'. $^{2}$ Someone had to keep a watchful eye over all these new arrivals, and beyond that someone had to ensure that their integration would proceed in such a way that business would not be disrupted.

Foremost among this collection of elite businessmen that ruled Los Angeles in the first decades of the $20^{\text {th }}$ century were members of the Otis-Chandler dynasty, owners and operators of the Los Angeles Times. Harrison Gray Otis, who became first publisher and eventual owner of the paper in the 1880s, wasted little time before using his editorial control of the Times to promote a utopian vision of Los Angeles as a capitalist enclave. This utopia rested on one fundamental premise - that industrial freedom, the open-shop, would be the ultimate guarantor of prosperity for all the city's inhabitants. ${ }^{3}$ According to a biographer, Otis's motivation stemmed from a conviction that the right to work was an American freedom, and through a combination of American exceptionalism and superhuman self-belief, a freedom that was both inherently just and self-evidently guaranteed to reward talent and stimulate growth. Backed by this conviction, Otis waged a pioneering fight to eliminate the International Typographical Union from his workplace after they began probably the first real strike the city had seen in 1883. ${ }^{4}$ Otis's drawn-out struggle against his own staff provided the cities other employers with an inspiring example of an embattled employer who ultimately defeated the strikers, as well as a warning of the potential financial cost if their own workers were allowed to organize.

Over the following decades, Otis, his allies, and their successors provided financial and ideological backing to organisations and individuals who shared in this vision-notably including the Merchants \& Manufacturers Association [M\&M], the Commercial Federation of California [CFC], the Better America Federation [BAF], and Southern Californians Incorporated [SCI]. These groups might variously be characterized as industry associations, open-shop activist groups, surveillance operations, or propaganda bureaus, all geared towards anti-labour,

\footnotetext{
${ }^{2}$ Carey McWilliams, Southern California Country, (New York: Duell, Sloan \& Pearce, 1946), pp.134-5.

${ }^{3}$ The 'open-shop' is a system of industrial organisation that, in its simplest interpretation, promotes the ability for employees to choose whether or not they accept union representation. In Los Angeles, a more militant version of the 'open-shop' was pursued; one in which organised labour was forcibly excluded from the city's places of employment. For a broad perspective on the open-shop movement, see Allen M. Wakstein, 'The Origins of the Open-Shop Movement, 1919-1920', The Journal of American History, Vol. 51, No. 3, December 1, 1964, pp. 460475.

${ }^{4}$ On the ITU strike, and Otis's involvement in it, see Richard Connelly Miller, 'Otis and His Times: The Career of Harrison Gray Otis' (Unpublished Ph.D Diss., University of California, 1961); William Spalding, Autobiography of a Los Angeles Newspaperman, 1874-1900, (San Marino: Huntington Library Press, 2007)
} 
pro-capital activism on a variety of levels. When Otis died in 1917, his role as the chief conservative philanthropist in Southern California passed to his son-in-law Harry Chandler, who used the paper and its anti-union stance to complement his involvement in various real estate ventures, agricultural enterprises and other activities.

During this period the man colloquially known as the 'Governor of Southern California' used his enormous fortune and influence to continue Otis's anti-labour, anti-reform political work, arguably eclipsing even Otis in the success of these pursuits. ${ }^{5}$ Between 1910, the year that a bomb under the Times building attacked the physical headquarters of Los Angeles' fledgling oligarchy, and 1930, shortly after the economic collapse that almost brought it down, the city's population more than quadrupled. According to historical census data, the population of Los Angeles County in April 1910 was 504,131; twenty years later, it was 2,208,492. ${ }^{6}$ The ground for this expansion had been prepared in every sense of the word by Otis and Harry Chandler, as well as their allies, including such well-known Californian figures as Henry Huntington and Moses Sherman.

Insights borrowed from specialist scholars on contemporary surveillance have proven useful to help inform this study. One useful concept was Kevin Haggerty's 'Surveillant Assemblage', a modern formulation intended to update Michel Foucault's work on modernist systems of control.7 Foucault's elegant model took the theoretical 'panopticon' prison design of Jeremy Bentham and re-imagined it as a metaphor for real-world power systems based on surveillance, data-collection, and the threat of public exposure-'disciplines' within which citizens would regulate their behaviour based on the knowledge they are constantly being

\footnotetext{
${ }^{5}$ It is believed that Harry Chandler's personal papers were destroyed either on his death in 1944, or sometime during his life, perhaps as a result of a congressional investigation into his links with anti-labour activities in the 1930s. Despite widespread recognition of his influence, this lack of documentation has hampered a detailed understanding of his role in Californian history. For an uneven attempt to rectify this absence, see-Jack Hart, 'The Information Empire: A history of the "Los Angeles Times" from the Era of Personal Journalism to the Advent of the Multi-Media Communications Corporation', Unpublished Ph.D. Dissertation: University of Madison-Wisconsin, 1975.

${ }^{6}$ California Department of Finance, '1850-2010 Historical US Census Populations of Counties and Incorporated Cities/Towns in California', Accessed 17/2/13 from

http://www.dof.ca.gov/research/demographic/state census data center/historical census 1850-2010/view.php

7 The 'Surveillant Assemblage' concept is borrowed from French authors Giles Deleuze \& Felix Guttari, via Kevin Haggerty \& Richard V. Ericson, 'The Surveillant Assemblage', The British Journal of Sociology, Vol. 51, No. 4, 2000, pp. 605-622.
} 
watched. ${ }^{8}$ Haggerty recently proposed the surveillant assemblage as a more flexible model which better incorporates non-state actors into Foucault's framework, while preserving the fundamental notion of citizen self-regulation through the belief that their actions were scrutinized. Although this thesis departs significantly from the ultimate use that Haggerty intended, the concept itself remains useful since it points to the effect that this repressive 'discipline' has had upon Los Angeles's history, as well as for its conceptual utility in conveying the diffuse nodal points that made up the loose alliance of California surveillance groups. ${ }^{9}$ In the case of this study, the range of actors included law enforcement, prominent businessmen and their employer associations, labour spies, patriotic organisations, public officials, and the mass media, particularly the Los Angeles Times.

A key component of the California surveillance coalition was the active involvement of a variety of private-sector surveillance operatives and groups. Though private-sector surveillance is a broad catch-all phrase, in the earliest context of this enquiry it is usually understood to mean the self-publicizing private detective agencies that flourished from the 1870s through to the 1920s. The William J. Burns Detective Agency was one well-known group among Californians, its founder famed for his role in capturing the bombers of the Los Angeles Times building in 1910, before later becoming head of the Bureau of Investigation in the early 1920s. Scholars have previously noted the role of such detective agencies in performing private-sector surveillance, particularly in targeting unions, pacifists \& radicals on behalf of a business clientele motivated by a fear of lost profits. ${ }^{10}$ Through performing the work of industrial espionage, private detectives legitimized, systematized, and commodified the routine

\footnotetext{
${ }^{8}$ Michel Foucault, Discipline and punish: the birth of the prison, (New York: Pantheon Books, 1977).

${ }^{9}$ Haggerty uses the surveillant assemblage to describe a kind of convergence or singularity, an abstract yet vaguely historical moment at which discrete yet overlapping layers of surveillance become both all-encompassing and coordinated-the realization of a hidden yet near-totalitarian surveillance society. This thesis uses Haggerty's term as a provocation, searching for evidence of such a phenomenon in the historical record. As a result I prefer the term surveillant 'coalition' or 'network', as the use of 'assemblage' would prematurely proclaim its discovery. ${ }^{10}$ For examples, see Robert P. Weiss 'Private Detective Agencies and Labor Discipline in the United States, 18551946', The Historical Journal, Vol. 29, No. 1, 1986, pp. 87-107;___'From Cowboy Detectives to Soldiers of Fortune: Private Security Contracting and its contradictions on the New Frontiers of Capitalist Expansion', Social Justice, Vol. 34, No. 3-4, 2007-8, pp. 1-19; Kevin Kenny, Making sense of the Molly Maguires, (New York: Oxford University Press, 1998); George O'Toole, The Private Sector: private spies, rent-a-cops, and the police-industrial complex, (New York: W.W. Norton, 1978); Robert Michael Smith, From Blackjacks to Briefcases: A History of Commercialized Strikebreaking and Unionbusting in the United States, (Athens: Ohio University Press, 2003); Frank Morn, 'The eye that never sleeps' : a history of the Pinkerton National Detective Agency, (Bloomington: Indiana University Press, 1982).
} 
surveillance of political thought antagonistic to the ideology of their employers among the late nineteenth century industrial elite. The philosophy of these employers coupled American exceptionalism and anti-radicalism with a fervent belief in the transformative power of capital. Protecting society from radicals and protecting capital from labour were thus analogous tasks, a useful and self-evident overlap that helps to explain the close associations that later formed between private and state surveillance operatives.

In addition to detective agencies, citizen groups motivated by political, patriotic or puritanical motivations began performing counter-subversive surveillance during WWI. There have been precious few historical studies of these kinds of early private-sector surveillers. Examples include Joan Jensen's The Price of Vigilance, the definitive history of the American Protective League [APL] - a patriotic vigilante group with local chapters scattered across the United States active in the surveillance and repression of pacifists, draft-dodgers, socialists, German-Americans and other assorted 'subversives' during WWI. ${ }^{11}$ The APL provided a formative experience for many counter-subversives motivated by patriotic fervour, whose members often maintained their vigil long after the APL was formally disbanded. More recently, Jennifer Fronc has explored the fluid relationship between public and private spies in New York, seeking to connect private patriots there with the establishment of state agencies like the Federal Bureau of Investigation $[\mathrm{FBI}]$. Her work traces this evolution via the often puritanical crusades of individual (and networked) operatives out to monitor the activities of promiscuous New York women, radicals, blacks, immigrants and other potential disruptors of a sexually and morally 'decent' white Christian middle-class. ${ }^{12}$

If Christian morality was indeed a significant motivation for the practitioners of political and sexual surveillance in New York, California's private spies in the early $20^{\text {th }}$ century were far more mercenary by comparison. In fact, it is clear that many of the state's professional surveillers had links with a pre-existing industry set up to enforce labour discipline in the $19^{\text {th }}$ century. As elsewhere, California employers had relied on private detectives and other

\footnotetext{
${ }^{11}$ Joan Jensen, The Price of Vigilance, (Chicago: Rand McNally, 1968); General Ralph Van Deman, one of the central figures of this thesis, was involved in bringing the APL under the auspices of Military Intelligence in 1917. For Van Deman's terse account of the APL's quasi-deputisation, see Ralph Weber (ed.), The Final Memoranda: Major General Ralph H. Van Deman, USA Ret., 1865-1952, (Wilmington: SR Books, 1988), pp. 30-31.

12 Jennifer Fronc, New York Undercover : Private Surveillance in the Progressive Era, (Chicago: University of Chicago Press, 2009).
} 
professional strike-breakers prior to 1900, but amidst the spirit of reform in the decade prior to World War One this practice seems to have become less palatable to the public. Robert Michael Smith illuminates this shift in his discussion of a 1907 Streetcar strike in San Francisco as a particular turning point-a strike that resulted in a particularly bloody crackdown by 'King of the Strike-breakers' James A. Farley and his contingent of out-of-town muscle. ${ }^{13}$ The popular backlash against the brutal tactics of Farley and his employers forced the recognition by resourceful anti-union entrepreneurs there was money to be made by this new environment, that special expertise would be required to exert discipline without overt force, and that an effective surveillance apparatus would be needed to accomplish both. ${ }^{14}$ He writes - 'with lucrative business opportunities promised by employers' continuing reluctance to bargain collectively with their workforces, those who preyed upon industrial unrest demonstrated a remarkable ability to invent new services'. ${ }^{15}$ Smith's work demonstrated how the mutually beneficial relationship between surveillance and capital in California evolved and adapted to the fickle winds of popular and political opinion, ensuring the longevity and effectiveness of their alliance.

Domestic unrest during the First World War convinced the government of the United States that it needed a dedicated official agency tasked with general counter-subversive surveillance. Soon it had several. Emboldened with new powers and legislative teeth, the three main organisations performing domestic surveillance of US citizens after WWI included the Department of Justice's Bureau of Investigation (later the FBI), The Military Intelligence Corps of the US Army (usually referred to as G-2 for its internal designation), and the Office of Naval Intelligence $[\mathrm{ONI}]$. Complementing and often cooperating with national groups were specialized groups of officers within local and state law enforcement, often known colloquially as 'Red Squads'. Historical scholarship on the FBI is extensive, and much is known of the motivations, practices, and personnel of the domestic surveillance component of that agency. ${ }^{16}$

\footnotetext{
${ }^{13}$ Robert Smith, From Blackjacks to Briefcases: A History of Commercialized Strikebreaking in the United States, (Athens: Ohio University Press, 2003)

14 Ibid, pp. xv-xvi.

${ }^{15}$ Ibid, p. xiv.

${ }^{16}$ On the FBI and the Department of Justice, see: Kenneth O'Reilly, Hoover and the un-Americans: the FBI, HUAC, and the red menace (Philadelphia: Temple University Press, 1983); Athan G Theoharis, The FBI \& American democracy : a brief critical history (Lawrence: University Press of Kansas, 2004); __, Spying on Americans : political surveillance from Hoover to the Huston plan (Philadelphia: Temple University Press, 1978); Regin Schmidt, Red
} 
Prior to World War Two however, the FBI's surveillance programs in California were minimal, while surveillance of Californian citizens by the military was far more prevalent. Joan Jensen, Alfred McCoy, and Roy Talbert have made significant contributions to the history of the army and navy intelligence agencies, particularly when both continued their surveillance of American citizens beyond their original wartime mandate. ${ }^{17}$ These historians have ably demonstrated how what was initially a military activity directed at foreign enemies became a political activity during peacetime-the defence of an American status quo from domestic radicals.

Public surveillance after WWI at the local level was handled by dedicated Intelligence Bureaus established in several Californian police forces, their members and leaders often drafted from prior careers in private detective agencies or military intelligence. At the state level, the California Bureau of Identification was tasked with coordinating city and county law enforcement efforts. Former American Civil Liberties Union [ACLU] researcher Frank Donner has written several important books on the topic of both Red Squads and surveillance agencies across all layers of government. ${ }^{18}$ Donner constructs a useful definition of the practice of surveillance that is both flexible and comprehensive, and entails five key activities- $1>$ 'the physical surveillance of a subject', whether discrete or otherwise; 2> 'a body of techniques' developed by surveillance specialists, which incorporate such activities as wiretapping, mail opening, and photography; $3>$ 'the compilation and dissemination of files and dossiers' on intelligence targets; $4>$ 'the assessment of file data', which would include cross-referencing, factchecking and other research activities; and 5> the aggressive use of such data to do injury to the subject' ${ }^{\prime}{ }^{19}$ Donner recognizes the implications and intended consequences of such intelligence work, arguing that 'whether the monitoring of subjects was open or clandestine, passive or aggressive, intelligence by itself became a force that demoralized and intimidated many targets

Scare: FBI and the Origins of Anticommunism in the United States, 1919-1943 (Copenhagen: Museum Tusculanum Press, 2000).

17 Joan M Jensen, Army surveillance in America, 1775-1980 (New Haven: Yale University Press, 1991); Alfred W McCoy, Policing America's empire : the United States, the Philippines, and the rise of the surveillance state (Madison: University of Wisconsin Press, 2009); Roy Talbert, Negative Intelligence : the army and the American Left, 1917-1941 (Jackson, Miss.: University Press of Mississippi, 1991).

${ }^{18}$ Frank Donner, Protectors of Privilege: Red Squads and Police Repression in Urban America, (Berkeley: University of California Press, 1990); __, The Age of Surveillance: the Aims and Methods of America's Political Intelligence System, (New York: Knopf, 1980); __ The un-Americans (New York: Ballantine Books, 1961).

${ }^{19}$ Donner, Protectors of Privilege, pp. 100-01 
and their supporters'.$^{20}$ Like much of the historiography on surveillance in the United States, Donner's work tends to privilege the East Coast and Federal agencies over private groups or citizen surveillers. Scott McLellan and Joseph Gerald Woods have ably rectified this lack scholarship on Californian police surveillance, their two dissertations spanning over sixty years of LAPD history. ${ }^{21}$ By supplying the fine details on local law enforcement in Los Angeles, their combined work has allowed this thesis to look for broader connections.

Though broadly concerned with foreign relations during the Cold War, Inderjeet Parmar's article on State-Private cooperative networks provides some useful assertions about the historical effect of informal surrogates of state power. ${ }^{22}$ According to Parmar, the foremost benefit to the state of outsourcing government activities to the private sector is the sublimation of responsibility, which allows the state to assume a position of distance when dealing with sensitive projects or ideas. For the private partners to this network, the benefits provided are varied and immense. Drawing on the ideas of Antonio Gramsci, Parmar argues that 'one of the most significant powers of dominant classes is the ability to establish private institutions that become fundamental to the exercise of state power' ${ }^{23}$ Once enmeshed in the structure of governance, these private institutions might leverage their position to attain substantial economic, ideological, or political rewards. While in a proximate position to state power these private groups are also able to disseminate their own ideological preferences-infusing the status quo with the private group's values and judgments. Thus the state-private network can be understood as a dynamic historical force that helps to produce what Gramsci called 'cultural hegemony' - the protective layer of pro-bourgeois ideology, formed by culture, politics and institutions, which exert a moderating, counter-revolutionary effect on the non-ruling social classes.

\footnotetext{
${ }^{20}$ Donner, Protectors of Privilege, pp. 102-3

${ }^{21}$ Scott Allen McLellan, 'Policing the Red Scare: The Los Angeles Police Department's Red Squad and the Repression of Labor Activism in Los Angeles, 1900-1940', (Ph.D. dissertation: UC Irvine, 2010); Joseph Gerald Woods, 'The Progressives and the Police: Urban Reform and the Professionalization of the Los Angeles Police', (Ph.D. Dissertation: UCLA, 1973).

22 Inderjeet Parmar, 'Conceptualising the state-private network in American foreign policy', in Helen Laville \& Hugh Wilford (eds.), The US Government, Citizen Groups and the Cold War: The state-private network, (New York: Routledge, 2006)

${ }^{23}$ Parmar, p.14.
} 
Though Californian law enforcement took some responsibility for anti-radical vigilance on the local and state levels after WWI the federal presence in the Western United States was almost negligible. Perhaps as a result private organisations filled in the gap, creating intercounty and sometimes inter-state networks to watch over suspected political subversives. Los Angeles' Better America Federation $[\mathrm{BAF}]$ is a particularly outstanding example of a business front group-visible, well-funded, antagonistic, sophisticated-with national ambition that viewed the surveillance and repression of political opponents as a fundamental practice. The tactics the BAF pioneered exerted a considerable influence on the development of Los Angeles in particular, and they likewise contributed substantially to wider conservative coalitions operating at state-wide and national levels. It is somewhat surprising then that so little has been written about the group, and that this little has itself often been of limited scope. The only dedicated study was written by Edwin Layton in 1961, but bears little appreciation of the larger context in which the BAF operated. ${ }^{24}$ More common are articles discussing the BAF as a peculiarity, expressive of a particular conservative ideology confined to the jazz-age capitalism of the 1920s..25 Yet they were far more. Like the local Merchants \& Manufacturers association from which they drew support, the BAF were part of a complex network of conservative activists and lobbyists fighting to maintain open-shop labour conditions in the city-a network whose origins can be traced back to the late $19^{\text {th }}$ century and the takeover of the Los Angeles Times by Harrison Gray Otis.

In order to understand the Otis-Chandler family and their role in the early history of Los Angeles surveillance, it is important to understand the formative moments they were involved in. Two such episodes stick out - the Owens Valley Aqueduct and related San Fernando Valley development, and the bombing of the Los Angeles Times building in 1910. Both episodes were highly public controversies at the time, and intimately linked to the way that the city's oligarchy combined city-building with fortune-building. In both cases the owners of the Los Angeles Times wielded their considerable influence to determine the course of events, steering them towards conclusions beneficial to their own. The Owens Valley Aqueduct made the Otis-Chandler

\footnotetext{
${ }^{24}$ Edwin Layton, 'The Better America Federation: A Case Study of Superpatriotism,' Pacific Historical Review, Vol.30, No. 2 (May 1, 1961), pp.137-147; see also Paul L. Murphy, 'Sources and nature of intolerance in the 1920s', The Journal of American History, Vol. 51, No. 1, (June 1964), pp. 60-76.

25 Mike Davis, 'Sunshine and the Open Shop: Ford and Darwin in 1920s Los Angeles,' in Tom Sitton and William Deverell (ed.), Metropolis in the Making: Los Angeles in the 1920s, (Berkeley: University of California Press, 2001).
} 
dynasty rich, securing their influence while guaranteeing the future expansion of a city over which they reigned. ${ }^{26}$ The bombing sank the campaign of an early socialist challenger to their political dominance, and simultaneously smeared labour with radicalism and taint of propaganda by the deed. ${ }^{27}$ In both episodes the ideological influence exerted by the Chandler family through their ownership of the Times was significant, and further heightened by considering the added effect of their various memberships in local political and business associations. The persuasive power of the Los Angeles Times as an ideological loudspeaker for pro-employer conservatism is a significant causal factor in this thesis, and one that is discussed throughout.

Any historian writing about California must necessarily acknowledge the multiple volumes written by Kevin Starr on the state's development since its entrance into the Union in 1850. ${ }^{28}$ Utilizing the familiar cliché of California as both container and producer of dreams, Starr has fused social, cultural, and political history into a grand narrative of a state where inevitably, Starr claims, 'the dream outran the reality'. ${ }^{29}$ As this perhaps suggests, Starr's exploration of California is a highly literary one, concerned with documenting a figurative or imagined state

\footnotetext{
${ }^{26}$ On the Owens Valley episode, see-Andrae Norskog, Communication to the California Legislature Relating to the Owens Valley Water Situation, (Sacramento: California State Printing Office, 1931); Morrow Mayo, Los Angeles, (New York: A. A. Knopf, 1933); Carey McWilliams, Southern California Country, (New York: Duell, Sloan \& Pearce, 1946); William G. Bonelli, Billion Dollar Blackjack, (Beverly Hills: Civic Research Press, 1954). More recently, William Kahrl positioned Lippincott as the chief villain of the piece in his Water and Power: The Conflict over Los Angeles' Water Supply in the Owens Valley, (Berkeley: University of California Press, 1982), and in __,'The Politics of California Water: Owens Valley and the Los Angeles Aqueduct, 1900-1927: II. The Politics of Exploitation,' California Historical Quarterly 55, no. 2 (July 1, 1976), pp.98-120; W. W. Robinson, The Story of San Fernando Valley, (Los Angeles: Title Insurance and Trust Co., 1961), as well as 'Myth-making in the Los Angeles Area', Southern California Quarterly, Vol. 45, No. 1, 1963, pp. 83-94; Abraham Hoffman, 'Joseph Barlow Lippincott and the Owens Valley Controversy', Southern California Quarterly, Vol. 54, No. 3, 1972, pp. 239-254.

${ }^{27}$ On the bombing and the conviction of the conviction of the McNamara brothers, see Herbert Shapiro, 'The McNamara Case: A Crisis of the Progressive Era', Southern California Quarterly, No. 15, 1977, pp. 271-288; 'The McNamara Case: A Window on Class Antagonism in the Progressive Era', No. 70, 1988, pp. 69-94; Daniel Johnson, 'No Make-Believe Class Struggle': The Socialist Municipal Campaign in Los Angeles, 1911', Labor History, Vol. 41, No. 1, 2000, pp. 25-45; Also see-Ortie McManigal, The National Dynamite Plot (Los Angeles: Neale co., 1913); William Burns, The Masked War (New York: George H. Doran co., 1913). Both of these accounts were written by key participants-McManigal was a defendant who escaped jail by testifying against his co-defendants, Burns was the detective who arrested them all.

${ }^{28}$ Kevin Starr, Americans and the California dream, 1850-1915 (New York: Oxford Univ. Pr., 1973); Inventing the dream : California through the progressive era (New York: Oxford Univ. Pr., 1985); Material Dreams: Southern California through the 1920s (New York: Oxford Univ. Pr., 1990); Endangered dreams: the Great Depression in California (New York: Oxford Univ. Pr., 1996); The dream endures: California enters the 1940s (New York: Oxford Univ. Pr., 1997); Embattled dreams: California in war and peace, 1940-1950 (New York: Oxford Univ. Pr., 2002); Golden dreams: California in an age of abundance, 1950-1963 (New York: Oxford Univ. Pr., 2009).

${ }^{29}$ Starr, Americans and the California dream, 1850-1915, p. viii.
} 
as much as a literal one. Starr's books are thus loaded with myth and metaphor-Babylon, El Dorado, the Iliad, the 'City on the Hill' etc., concepts he uses as prisms through which to separate and examine the disparate light of Californian lives. Yet the magisterial nature of Starr's historiography sometimes precludes intimate understanding, particularly when it comes to the specific details of these lives. Though his later volumes take a firmer approach to narrative, particular his account of the depression it is clear that Starr is above all striving to nderstand the formation (and formulation) of Californian identity - to discover which myths and metaphors are most applicable, or which overarching genre of tragedy, comedy or farce most eloquently encapsulates the Californian experience.

There is a strong historiographical tradition of innovative approaches to writing histories of the city of Los Angeles that touch on the themes of this thesis. Mike Davis's City of Quartz, for example, updates Kevin Starr's metaphors with his own exploration of the city as a built environment, a literal geographical superstructure atop the economic base of the city. ${ }^{30}$ The Marxist analytical foundation underpinning Davis's investigation of such a famously capitalistic city lends his work a dystopic bent, and the varied nature of his approach (architecture, literature, film etc.) provides him with a wealth of material to fortify that interpretation. Los Angeles corrupts its intellectuals, Davis argues, and it was the right-wing business elite who gave the city its decadent, contagious heart. John Laslett's recently completed history of Los Angeles workers takes a survey approach, concluding that the influence of the open-shop lobby was the determining factor that crippled Los Angeles labour in relation to comparative cities, an argument very much supportive of this thesis. ${ }^{31}$ Becky Nicolaides took a different approach in My Blue Heaven, composing a fine-grained analysis of the depression's exertions on one working class area of Los Angeles. ${ }^{32}$ A recent contribution that focuses on the dissent to local conservatism is Daniel Hurewitz's Bohemian Los Angeles and the making of modern politics, which proceeds from the premise that historians have failed to adequately acknowledge the role of non-conformists, radicals, minorities, and leftists in carving

\footnotetext{
${ }^{30}$ Mike Davis, City of Quartz: Excavating the Future of Los Angeles (New York: Vintage Books, 1992).

31 John Laslett, Sunshine was never enough, Los Angeles Workers, 1880-2010, (Los Angeles: University of California Press, 2012).

32 Becky Nicolaides, My Blue Heaven: Life and Politics in the working-class suburbs of Los Angeles, 1920-1965, (Chicago: University of Chicago Press, 2002).
} 
out an 'alternative' Los Angeles. ${ }^{33}$ This thesis aims to perform a similar task for the earlier period, exploring the forms of resistance that targets of political and economic surveillance were compelled to adopt, and arguing that the tactics of their opponents became a ubiquitous part of political activism in the state regardless of one's position on a left-right spectrum.

A thorough history of political surveillance and repression in California must necessarily take an interest in its targets as well as in its exponents. All throughout the period, keen-eyed observers noticed the connections between business profits and police repression; between conservative media outlets and anti-communist activism; and between local politics and surveillance professionals. Progressive or socialist politicians such as Job Harriman, Upton Sinclair, and Hiram Johnson built careers on their outspoken criticism of the conservative status quo and its assorted functionaries. Having been targets of numerous and concerted right-wing attempts to derail their political careers, these public figures were understandably committed to exposing their enemies' machinations at every turn. ${ }^{34}$ As a prolific author Sinclair published extensively on the activities of his political opponents. ${ }^{35}$ At other times leftist organisations were critical of the reactionary apparatus they saw emerging. The ACLU in particular was extremely active in this regard, taking up the defence of many targets of the surveillance coalition. ${ }^{36}$ Other critics were liberal journalists or activists, such as Franklin Hichborn, Elizabeth Kerby, John Randolph Haynes and Carey McWilliams. Haynes has attracted the attention of at least one biographer, while Carey McWilliams has been both the subject of historical inquiry as well as an author of Californian history himself. ${ }^{37}$

\footnotetext{
${ }^{33}$ Daniel Hurewitz, Bohemian Los Angeles and the making of modern politics (Berkeley: University of California Press, 2007).

${ }^{34}$ Harriman and Johnson have both attracted scholarly attention, perhaps because of their status as major national politicians during this phase of Californian history. On Harriman, see Daniel Johnson, "No make-believe Class Struggle': The Socialist Municipal Campaign in Los Angeles, 1911', Labor History, Vol. 41, No. 1, 2000, pp. 25-45; on Johnson, see Spencer Olin, California's prodigal sons: Hiram Johnson and the Progressives, 1911-1917 (Berkeley: University of California Press, 1968); or more recently, Richard Lower, A bloc of one: the political career of Hiram W. Johnson (Stanford: Stanford University Press, 1993)

${ }^{35}$ In both of the following books Sinclair describes features of the Californian surveillant network that would later become vocal opponents of his political ambitions in the 1930s-Upton Sinclair, The brass check, a study of American journalism (Pasadena, Calif.: The author, 1920); (Pasadena, Calif.: The author, 1923).

${ }^{36}$ Scholarship on the ACLU in Southern California is limited, but is often discussed by way of Upton Sinclair's EPIC campaign-Sinclair was a founding member of the Southern California ACLU.

37 On Haynes, see-Tom Sitton, John Randolph Haynes: California Progressive, (Stanford: Stanford University Press, 1992); on McWilliams, begin with-Daniel Geary, 'Carey McWilliams and and AntiFascism, 1934-1943', Journal of
} 
McWilliams is probably best remembered for Factories in the Field, his incredibly prescient warning about the dangers of large-scale agribusiness to our social and environmental health. ${ }^{38}$ The Californian agricultural system that he termed 'Farm Fascism' functioned as a vertically integrated network of repression which co-opted every available aspect of local power to defend the economic system on which it was built. Starr agreed, describing the labour relations in California agriculture as 'chillingly suggestive, in certain instances of consolidations and arrangements between the public and private sectors which can arguably be compared to the fascist consolidations of Italy, Germany, and Spain'. ${ }^{39}$ Though scholars continue to debate the accuracy of the term, it was appropriate enough for observers like McWilliams, and an interpretation that is supported by this thesis. ${ }^{40}$

Until the early 1990s scholarship on the origins of California's particular brand of Republican conservatism was sparse-a strange omission considering the state produced the two leading conservative presidents of the later twentieth century. Even recent historiography tends to highlight Arizona senator Barry Goldwater's unsuccessful campaign for the presidency in 1964 as the key mobilisation in the creation of a 'New Right' conservative political bloc within the Republican Party, incorporating California's national aspirations within a broad southwestern framework. Nevertheless, Lisa McGirr is rightly recognized for her contribution in highlighting the significance of the grassroots aspect of Californian conservative mobilization although her work, like other historians' accounts, has left the preceding years relatively vague. ${ }^{41}$ While McGirr notes that conditions were favourable for conservative ideologies to flourish in Southern California during the 1950s and early 1960s, her real interest is in outcomes, not the longer-term conditions that produced them. Kurt Schuparra has extended this

American History, Vol. 90, No. 3, December 2003, pp. 912-934; Greg Critser, 'The Making of a Cultural Rebel: Carey McWilliams, 1924-1930', Pacific Historical Review, No. 55, 1986, pp. 226-255; Peter Richardson, American prophet the life \& work of Carey McWilliams (Ann Arbor: University of Michigan Press, 2005).

${ }^{38}$ Carey McWilliams, Factories in the Field: The Story of Migratory Farm Labor in California (Boston: Little, Brown, 1939).

${ }^{39}$ Starr, Endangered Dreams, p. 193; also see-Nelson A. Pichado Almanzar and Brian W. Kulik, American Fascism and the New Deal: The Associated Farmers of California and the Pro-Industrial Movement (Lanham: Lexington Books, 2013); Stephen Schwartz, From West to East: California and the Making of the American Mind (NY: Simon \& Schuster, 1998)

${ }^{40}$ On Californian agriculture, also see-Daniel Cletus, Bitter Harvest: A History of California Farmworkers, 18701941 (Ithaca, N.Y.: Cornell University Press, 1981).

${ }^{41}$ Lisa McGirr, Suburban warriors : the origins of the new American Right (Princeton, N.J.: Princeton University Press, 2001). 
timeframe in his recent work to the years immediately following WWII, but is similarly limited by a focus on explaining Ronald Reagan's election as governor of California in $1966 .{ }^{42}$ As this thesis will show, the broad political narrative of Southern California is not one of conservative 'emergence' after World War II, but of a systematically enforced conservative dominance from at least 1918, merely punctuated by brief intervals of challenge and tenuous reform enacted by labour, socialist, progressive, New Deal, and Communist Party-allied organisations and individuals.

As a result this thesis challenges the prevailing periodisation of the national history of the conservative offensive against the left between the 1920s and 1950s. This periodisation has divided it into the first and second 'Red Scare' periods to demarcate the political situation in the United States as a whole. The First Red Scare is thus described as a period occurring between 1919-1921, characterised by a fear of the October Revolution spreading to the U.S. through radical Russian and Jewish immigrants and militant labour unions. After two years of escalating violence and official reprisals the First Red Scare is supposed to have wound down to a quiet conclusion-presaged by public reaction against the government's crackdown as well as the acquittal of the vast majority of accused radicals rounded up in hastily executed raids. While broadly accurate, this conventional interpretation fails to account for on-going mobilisation in the 1920s by patriotic groups, veterans' organisations, police forces and various investigative agencies, all of whom continued to capitalise on perennial public fears of radical insurgence. ${ }^{43}$ For some conservatives in California, the acquittal of those arrested in the 1919-1920 raids merely represented a lack of resolve by the federal government to deal with the urgent threat posed by radicals, and only reinforced the conviction of hard line anti-Bolsheviks of the need to form local organisations as a corrective.

Scholarship following the traditional narrative of two discrete 'scares' continues to be produced. Many influential historians have framed their narratives within this chronology, though usually as a product of their wider inquiries into McCarthyism, HUAC and the FBI. ${ }^{44}$ In

\footnotetext{
${ }^{42}$ Kurt Schuparra, Triumph of the right : the rise of the California conservative movement, 1945-1966, (Armonk, N.Y.: M.E. Sharpe, 1998).

${ }^{43}$ For another historian who has noticed the same tendency, see-Kathryn Olmsted, 'Quelling Dissent', Boom: $A$ Journal of California, Vol. 1, No. 2, 2011, pp. 59-74.

${ }^{44}$ See, for example-Ellen Schrecker, 'McCarthyism's Ghosts: Anticommunism and American Labor', New Labor Forum, no. 4 (April 1999): 7-17; Many are the crimes : McCarthyism in America (Boston: Little, Brown, 1998);
} 
such cases an institutional focus has tended to again privilege the East Coast over the West. Regin Schmidt's Red Scare: FBI and the origins of anticommunism in the United States, 1919-1943, is another recent study to follow this pattern, though to Schmidt's credit he does attempt to allow for regional variations. ${ }^{45}$ Based heavily on Carey McWilliams' seminal 1946 work Southern California Country, Schmidt does note the importance of private-public partnerships in the origins of anticommunism, but claims that these kinds of alliances ended in 1924 when the Bureau of Investigation underwent internal reform in the wake of its transformation into a federal agency. This claim is hard to follow in light of contradictory evidence. This thesis will instead demonstrate the absolute opposite; that the potency of California's surveillance network stemmed from its public-private surveillance partnerships. Moreover, despite the isolation suggested by the title of McWilliams' famous book, Southern California was no 'island on the land'-instead the Southern Californian surveillance coalition was itself a node in an interconnected national network of professional patriots and dedicated anti-communists, whose significance to the political history of the United States has tended to be underestimated or otherwise bookended through periodisation. ${ }^{46}$

The Second Red Scare, usually dated from 1947-1954 and thus associated with or referred to as McCarthyism, also needs to be called into question because a second cycle of conservative resurgence against the Californian left clearly predates the rise of Joseph McCarthy in 1950. Assuming such a cycle even exists, by starting with the House Un-American Activities Committee's focus on Hollywood in 1947 the conventional interpretation leaves a twenty-year gap in a much longer history of surveillance focused on the Hollywood left. Many of the progressive challenges to Californian conservatism during the 1920s and 1930s were either aided by or partially played out in Hollywood-both as a location where politically active individuals worked and lived, and as a commercial/artistic landscape where ideology is created,

Kenneth O'Reilly, Hoover and the un-Americans : the FBI, HUAC, and the red menace (Philadelphia: Temple University Press, 1983); Athan G Theoharis, The FBI \& American democracy : a brief critical history (Lawrence: University Press of Kansas, 2004); ___, Spying on Americans : Political surveillance from Hoover to the Huston plan (Philadelphia: Temple University Press, 1978); Storrs, Landon. The Second Red Scare and the unmaking of the New Deal left, Princeton: Princeton University Press, 2013.

${ }^{45}$ Regin Schmidt, Red scare : FBI and the origins of anticommunism in the United States, 1919-1943 (Copenhagen: Museum Tusculanum Press, University of Copenhagen, 2000).

${ }^{46}$ The phrase 'an island on the land' is the subtitle of McWilliams' 1946 book Southern California Country- Carey McWilliams \& Erskine Caldwell, Southern California Country: An Island on the Land (New York: Duell, Sloan \& Pearce, 1946). 
mediated, represented on celluloid and shared with the world. John Sbardelatti's J. Edgar Hoover goes to the Movies suggests that it was the FBI that pushed HUAC into investigating Hollywood in the early 1940s, a claim challenged by the results of this study, which finds an earlier impetus for investigating Hollywood. ${ }^{47}$

Though it is understood how locally and later nationally prominent individuals such as Richard Nixon and Ronald Reagan built their political careers out of red-baiting, it is far less understood how such figures were beneficiaries of a much longer tradition of anti-Communist activism practiced by members of California's surveillance community, who almost exclusively were also Republican Party activists. This thesis will attempt to rectify that misconception by filling in the gap between the periods demarcated by the first and second red scares, demonstrating how a succession of localised red scares were routinely manufactured by California's surveillance groups or their political allies when it suited their needs.

Although the surveillance network in California was not the only one of its kind in the United States between the two World Wars, it is distinguished by the availability of the sources that chronicle it. The city of Chicago, to take one example, harboured several similar groups such as Harry Jung's American Vigilant Intelligence Federation [AVIF], who also enjoyed a modicum of quasi-legal cooperation from public officials, and was in regular contact with California cohorts such as the BAF. Unfortunately for historians, whatever archives the AVIF compiled during their 30 or so years of operation are lost, or otherwise unavailable to researchers. ${ }^{48}$ This is not the case in California, partly thanks to the energy and intelligence of a small group of wary individuals and organisations who compiled their own archives to spy on the spies. This counter-surveillance attracted official attention, and when Senator Robert M. La Follette Jr. formed a Senate Committee in 1936 to investigate violations of the rights of labour, California came to dominate the committee's focus. Aided by an array of liberals and leftists of various affiliations, the volume of evidence collected by the La Follette Committee suggests that California was exceptional both for the activities of conservative surveillance networks as well

\footnotetext{
47 John Sbardelatti, J. Edgar Hoover goes to the movies: the FBI and the origins of Hollywood's Cold War (Ithaca: Cornell University Press, 2012).

${ }^{48}$ Harry Jung was close to Robert McCormick, the reactionary publisher and owner of the Chicago Tribune, and McCormick offered Jung free office space in the Tribune building to conduct his surveillance work. It is speculated, though likely impossible to prove, that the surveillance materials of the AVIF were absorbed into the archives of the Chicago Tribune sometime during the 1940s or 1950s.
} 
the availability of evidence on them. Without such diligence by the counter-surveillers, this study of Californian surveillance networks would not be possible.

Other sources used to compile this history of conservative surveillance in California were assembled from a large variety of archival collections across the United States, a few of which still need closer scrutiny by historians. For example, this thesis contains probably the first quantitative work so far done on The Ralph Henry Van Deman papers at the National Archives in Washington, D.C., a vast archive comprising of hundreds of thousands of documents gathered as research material on the political activities of Californian citizens. Usually accompanied by the sobriquet 'the father of modern military intelligence', Van Deman retired in 1929 after a long career spying on America's enemies in the Philippines and elsewhere. Ostensibly driven by fears of a Bolshevik revolution in the United States, Van Deman resumed his life's work post-retirement from a modest San Diego bungalow, his wife serving as archival assistant. The vast repository of surveillance material that they collected over twenty years has received scant attention since its internment at the National Archives in the 1970s, and it was perhaps not until recent scholarship by Alfred McCoy that the influence of one of the most significant U.S. spymasters of the twentieth century was recognized..$^{49}$ Even so, McCoy's work is mostly focused on a demonstration of how Van Deman's techniques of colonial repression were translated to a domestic context-though masterful and full of significant insights into Californian history, his study is less concerned with Van Deman's role in Californian history than this thesis.

Similarly underappreciated, the Norman Leonard Collection at the San Francisco State University may well be one of the most significant archives for scholars of surveillance in the United States once its secrets are better understood. ${ }^{50}$ The Leonard collection was formed from the legal defence files of the law firm that represented union leader Harry Bridges in $1938-$ these files record the activities of the various groups aiming to expedite Bridges' deportation from the US, thereby severely undermining organised labour on the West Coast. This collection may well be the final repository of the La Follette Committee's investigative records, passed to

\footnotetext{
49 McCoy, Policing America's Empire; for the surveillance archive itself, see-The Ralph H. Van Deman Papers, 19291952, Senate Internal Security Subcommittee Special Collections, National Archives and Records Administration, Washington D.C. [Hereafter referred to as RHVD/NA]

${ }^{50}$ Norman Leonard Papers, Labor Archives \& Research Center, San Francisco State University.
} 
the law firm by committee staff who shared ideological and institutional links with West Coast labour. As a result the Leonard Collection contains completely novel counter-surveillance material revealing much about the activities, personnel and organisation of California's surveillance network. This thesis aims to advance historical scholarship by utilizing novel source material such as this, sources that are only beginning to yield their secrets.

Ultimately, the result of this research is a study of the creation and operation of a politically conservative surveillance network in California between 1918 \& 1939. While elements of this history have been described, the results only hint at the implications, suggesting scholars have yet to place all such elements within a comprehensive framework that acknowledges the effect of their actions when coordinated. By doing so, this thesis will aid an understanding of the leading role that conservative California played in a period of national growth of anticommunism, surveillance, and repression networks that have recognized and on-going implications for the political development of the United States of America. Another way to conceive of this suggestion is to think of California during the 1920s and early 1930s as a crucible for the conservative counteroffensive of 1938, denoted by an intense aversion to leftist radicalism, the involvement of the federal government in social legislation, and the insistent conflation of these two conservative bugbears. This then, I suggest, may be an alternative place to locate the beginnings of cold war anti-communism, and of the New Right that followed.

\section{Chapter Outlines}

The fervent desire of many of Los Angeles's business elite to preserve the city as an openshop 'utopia' is crucial to understanding how California's surveillance network came into being. The first chapter of this thesis will discuss the development and activities of the Better American Federation [BAF] and the Los Angeles Police Department [LAPD] in the years following WWI and into the 1920s - a period when both organisations, supported by the Los Angeles Times, exerted a powerful repressive influence hostile to organized labour and political dissent within the city. These two institutions, one privately funded, one publicly, established 
the surveillance practices and categories of suspicion that would shape Californian history for at least the next two decades.

The second chapter will discuss the activities of the BAF and LAPD Intelligence Bureau as they dealt with the depression and subsequent inflammation of radicalism during the first half of the 1930s. The decade began with a significant coup for both organisations when Los Angeles was visited by the House Committee to Investigate Communist Propaganda (the Fish Committee, 1930), which proved eager to host sensational revelations about communist influence in the United States. As the depression wore on new groups and individuals with diverse motivations began their own surveillance programs, linking up with the BAF and LAPD to form the beginnings of a surveillance network that shared resources, targets, informants and intelligence for the remainder of the decade. As the network's influence grew, it became increasingly involved in the state's response to the challenges posed by the depression.

By the second half of the 1930s the national political momentum had swung leftwards, empowering unions and chipping away at conservative control over former bastions such as Los Angeles. The threat posed by radical labour in California was growing, and the surveillance network worked to secure the information necessary to prosecute prominent labour leaders in high-profile trials. Concurrently, the network found a new national outlet for its work with the Special Committee to Investigate Un-American Activities (the Dies Committee, 1938-1942). Locked in a duel for the public's sympathy with a rival left-leaning committee - the Senate Subcommittee Investigating Violations of Free Speech and Rights of Labor (the La Follette Committee, 1936-1945), the Dies Committee used the collected surveillance material of the Californian network to help shape a national conservative bloc to challenge the New Deal. The final chapter will discuss how these committees' engagement with local allies on both sides of the political spectrum shaped the national response to political radicalism, to the depression, and to organised labour. The chapter concludes at the end of 1939, just as the outbreak of war temporarily halted a political struggle integral to the history of the United States, and one which continues well beyond the scope of this thesis. 


\section{CHAPTER 1: REPRESSION (1918-1930)}

If there should be disloyalty, it will be dealt with by a firm hand of stern repression; but, if it lifts its head at all, it will lift it only here and there and without countenance except from a lawless and malignant few-U.S. President Woodrow Wilson, 1917. ${ }^{51}$

The First World War provided Los Angeles' business community with the impetus to develop patriotic citizens' organisations which would both support the war effort and repress enemies new and old-radical dissenters, unionists, and pacifists. ${ }^{52}$ Through these proxies the city's capitalist class sought to control the city and state governments to prevent any progressive legislation that might impinge on business, especially in areas such as the public ownership of utilities and the rights of labour.

Two of these organisations were the Commercial Federation of California [CFC, 19171920] and its successor, the Better America Federation of California [BAF, 1920-?]. Like the Los Angeles Merchants \& Manufacturers, much of the BAF's power came from its strength as a bloc of influential businessmen, who would collectively isolate fellow employers who refused to join their ranks and enforce the extreme local interpretation of an open-shop. Usually denoting a workplace where union membership is not a required condition of employment, the BAF instead insisted that no union recognition or collective bargaining could occur within the city, and were prepared to employ propaganda alongside significant political pressure to achieve their aims. In addition to their role as enforcers of ideological adherence to industrial freedom, the CFC \& BAF used their influence in the state Capitol at Sacramento, exercising lobbying power to block reform and support desirable legislation that furthered their aims. However the BAF were not unopposed, and had attracted the suspicion of sharp-eyed observers who tracked the organisation's metamorphosis and activities. One of these was John Haynes, the direct democracy advocate and Los Angeles reformer who had previously served as physician to the

\footnotetext{
${ }^{51}$ Woodrow Wilson, 'War Message', April 2, 1917, accessed 11/02/14 from http://www.presidentialrhetoric.com/historicspeeches/wilson/warmessage.html

52 On patriotic citizenship and the First World War, see-Christopher Capozzola, Uncle Sam Wants You : World War I and the Making of the Modern American Citizen, (New York: Oxford University Press, 2008).
} 
Otis-Chandler family who published the Los Angeles Times. Thanks to Haynes, traces of their activities remain.

Throughout 1919 a series of deadly bombings combined with national unease about radical immigration from Europe to usher in the first 'Red Scare' - culminating at the end of the year with a series of Department of Justice raids targeting radical immigrants, especially anarchists and radical members of the Industrial Workers of the World [IWW], a radical leftist movement committed to the organisation of unions on an industrial scale. California was not immune to the zeitgeist, and enacted a state criminal syndicalism law to repress its own politically 'undesirable' inhabitants, whether foreign or native-born. The IWW in California had been the subject of quasi-state repression before, most famously in San Diego in 1912, where several 'wobblies' had been tarred and feathered by local vigilantes with official sanction. ${ }^{53}$ It was during the first years of the 1920s however, that the repression of the group reached its height.

This was particularly so at the port of San Pedro, which the IWW targeted for an organisation drive in 1921. IWW leaders believed that the organisation of San Pedro maritime workers would present a powerful symbol, breaking the open shop bastion wide open. With the aid of undercover operatives like William Hynes, the LAPD broke up IWW efforts through mass arrests, the collection of evidence against strike leaders, and the assent given to vigilantes to step in when required. The experience gained repressing the IWW demonstrated the value of a dedicated police unit to perform counter-subversive surveillance, and so out of San Pedro came the LAPD Radical section of the Intelligence Bureau - the 'Red Squad' which Hynes was assigned to lead.

Over the course of the 1920s Hynes and his surveillance operatives sought to define and understand the nature of the radical threat that they believed was poised to overthrow the US government. By doing so they were channelling a historical (and international) process of radical categorisation, one with roots that stretched at least as far back as the anti-radical

\footnotetext{
${ }^{53}$ On this episode, see-Michael Cohen, 'The Ku Klux Government: Vigilantism, Lynching, and the Repression of the IWW', Journal for the Study of Radicalism, Vol. 1, No. 1, 2007, pp. 31-56.
} 
crackdowns in Chicago's Haymarket square in May $1886 .{ }^{54}$ Nevertheless, in the aftermath of the IWW's defeat, these categories would be expanded to include other organisations, including the fledgling Communist Party of the United States [CPUSA], as well as affiliates and defenders of the right to dissent in California, including the American Civil Liberties Union [ACLU]. As the radical left evolved, so too did the measures required to defeat them. At the end of the decade this was demonstrated with a trial in the Imperial Valley that would determine the preferred format for the repression of political dissenters through into the 1930s.

\section{Criminal Syndicalism and the IWW}

One of the men who rose to prominence amongst Los Angeles patriots and businessmen during the war was Harry M. Haldeman. Haldeman had arrived in Los Angeles shortly before the bombing of the Los Angeles Times in 1910, quickly ingratiating himself with the OtisChandler clique. Described as 'forward-moving and aggressive' by at least one critic, Haldeman was successful both financially and as an enforcer of class discipline among Los Angeles business men. The active organizer of several interlocking employers' organisations, Haldeman was 'a strong speaker, a strong hater, a loyal man to his friends, a ruthless fighter' who nursed ambitions to become governor. Union men detested Haldeman, refusing to install machinery and plumbing known to have come from his establishment, the Pacific Pipe Supply Company. ${ }^{55}$ As a fund-raiser during the war, Haldeman became active in the patriotic-vigilante American Protective League [APL] which formed to discover disloyal elements and repress 'slackers' who opposed conscription. By taking full advantage of the patriotic mobilization, Haldeman had been able, with rapid success, to make himself one of Los Angeles' most vociferous defenders of Americanism.

\footnotetext{
54 On Haymarket see, for example-Paul Avrich, The Haymarket Tragedy, (Princeton: Princeton University Press, 1984); Timothy Messer-Kruse, The Haymarket Conspiracy: Transatlantic Anarchist Networks, (Urbana: University of Illinois Press, 2012).

${ }^{55}$ Ernest J. Hopkins, 'Report to the Immigration and Housing Commission on the Better America Federation and its attack on the Los Angeles Y.W.C.A.', 1920, Box 6, John R. Haynes Papers, University of California Los Angeles, p. 10. [Hereafter referred to as JRH/UCLA]
} 
After the armistice, Haldeman saw a need to remain on alert to prevent European radicalism from infecting the United States and Los Angeles in particular. One way he did so was through his leadership of several of the city's most influential patriotic and civic organisations, including the Commercial Federation of California and the Association for the Betterment of Public Service [ABPS]. Though ostensibly a business association, the CFC clearly had grander ambitions, and actively sought to influence the political views of its members as well as the wider public. For example, under CFC auspices Haldeman established a lobbying office in Sacramento designed to prevent pro-labour or reformist legislation being passed by the state legislature, while encouraging legislators to support desirable bills. ${ }^{56}$ Working on all sections of the political body, CFC publications were also distributed widely to the public, which the group sought to convert to its own, '100\% American' views. ${ }^{57}$

The Commonwealth, CFC's 'patriotic periodical with a punch', offers a vivid insight into the political imagination of the group, which amplified the brand of hostile conservatism expressed in the Los Angeles Times. ${ }^{58}$ Replete with vitriol, the CFC monthly eagerly denounced the IWW, Bolsheviks, and 'Parlor Bolsheviks', while celebrating the rapid expansion of the American Legion-the national veteran's organisation who would later become key anticommunist allies. In one brief satirical article titled 'Bolshevik Society Notes', the author chronicles the imagined debauches of local reds, declaring for example that 'Mr. and Mrs. Satan Bomflinger and their little daughter, Filthie, have left for Washington to attend the stabbing of certain high officials', while 'Mrs. Fanatica Felon announces the engagement of her daughter, Licentia, to Loaferman Ghoulovitch, Sloberinus Sovietoff, Dmitri Lowlife, Feodor Poisonoffski and Ivan Blackguardovik'. ${ }^{59}$ This bizarre juxtaposition featuring motifs of sexual promiscuity, political violence and Eastern European stereotypes gives the article a fevered and apocalyptic tone, an extreme representation of the anti-radical hysteria that loomed over the winter of 1919.

The ABPS on the other hand was an explicitly political organisation, a well-funded front group that Haldeman controlled as executive chairman of the group's campaign committee.

\footnotetext{
56 'Platform of the Better America Federation', no date, Box 6, JRH/UCLA.

${ }^{57}$ A handwritten note on one CFC publication notes that it was 'placed each week in the boxes of all teachers in the public schools' - Commercial Federation of California, Commonwealth, Vol. 3, No. 8, May 1920, Box 5, JRH/UCLA.

${ }^{58}$ Commercial Federation of California, Commonwealth, Vol. 3, No. 3, December 1919, Box 5, JRH/UCLA.

59 lbid.
} 
ABPS influence was well known, having been credited by one critic with having elected 'an overwhelming majority of the City Council and legislative candidates' in Los Angeles' 1918 municipal elections. ${ }^{60}$ Haldeman himself boasted of his role in this feat, claiming on one occasion to have elected six out of the nine members of the city council, including the council president. ${ }^{61}$ The Los Angeles Times corroborated Haldeman's claim, and also credited the ABPS with the election of ten state assemblymen endorsed by the Times for their opposition to prounion legislation proposed by what it called the 'anti-decent-government' element in the state legislature. ${ }^{62}$ Even with such control Haldeman was a plutocrat at heart, who wrote that his ultimate goal was the abolition of the state's elected legislature, to be replaced by a commission of fifteen who would exercise legislative power. ${ }^{63}$

Together, the CFC and ABPS applied their substantial political influence to pass bills that were determined to be favourable to Haldeman, his allies and sponsors. Perhaps the most significant bill that the CFC took credit for was California's Criminal Syndicalism Bill-which criminalised activism by individuals or organisations which agitated for radical political or economic change in California-and was worded broadly enough to be applicable to a range of 'undesirable' organisations or activities. ${ }^{64}$ Passed in May of 1919, not a single one of the legislators from Los Angeles voted against the bill, many of whom owed their offices to the ABPS. ${ }^{65}$ One of Haldeman's deputies later described the battle to 'get [the law] on the books and to keep it there' as the most significant achievement of the group's work, in clear recognition of the way that the law was employed, and the radical unionists it was used against. ${ }^{66}$

\footnotetext{
${ }^{60}$ Hopkins, p. 9.

61 'Platform of the Better America Federation', no date, Box 6, JRH/UCLA.

62 Horace W. Karr, 'Legislature to Bar Bolsheviki', Los Angeles Times, January 11, 1919, p.11.

${ }^{63}$ Haldeman reportedly stated such a commission "would be a great help to this organization because it could control 15 men much more easily than 120" -Anon., 'Platform of the Better America Federation', no date, Box 6, JRH/UCLA.

${ }^{64}$ For the text of the California Criminal Syndicalism Law, see the Appendix of this thesis.

${ }^{65}$ Woodrow C. Whitten, 'Criminal Syndicalism and the Law in California: 1919-1927, Transactions of the American Philosophical Society, Vol. 59, No. 2, 1969, p. 25.

${ }^{66}$ Norman Hapgood, Professional Patriots, (New York: A. \& C. Boni, 1928), p. 65; in 1932 Nation author George West agreed, calling the law 'a deliberate policy conceived and executed by Los Angeles employers as organized in the Better America Federation and the Merchants and Manufacturers' Association. It was strictly an industrial policy and a belief that legal terrorism would dispose effectively of labor unrest... a belief that they had always practiced up to the limit which public opinion would tolerate, a belief on which they found themselves able to act without restraint as a result of the anti-red hysteria of 1919 and since' - George P. West, 'After liberalism had failed', Nation, No. 116, May 30, 1932, p.629.
} 
Though the CFC claimed credit for successfully lobbying to ensure the Criminal Syndicalism bill's passage it was the news media, especially the Los Angeles Times, that helped determine the favoured targets of the law. California Governor William Stephens was a progressive Republican, but his attitudes towards radicals reflected the bombing of the previous Governor's mansion in December 1917, followed by a bizarre ransom threat shortly afterwards-both incidents the Times alleged to be the work of the Industrial Workers of the World. ${ }^{67}$ Five months later the Times reported that an IWW member had confessed to participation in a conspiracy to bomb the mansion for a second time. The Times described this as a 'new I.W.W. plot' despite there being no evidence that any group members had been involved in the first attack. ${ }^{68}$ The Times enthusiastically reported his subsequent denunciation of the IWW, repeating the Governor's conflation of the group with Russian revolutionaries when Stephens resolved that 'relentless efforts should and would be made to wipe out the American Bolsheviki'. ${ }^{99}$ Such examples demonstrate why the Criminal Syndicalism Bill was understood by contemporary Californians to be explicitly targeted at the Industrial Workers of the World. Thanks in part to lobbying by the CFC and the encouragement of the Times, the California legislature enacted the Criminal Syndicalism law on 30 April 1919. Law enforcement quickly began collecting evidence to be used in their crackdown on IWW members throughout California.

The first arrests on charges of Criminal Syndicalism in Los Angeles were made on October 1 1919, the opening salvo of what the Times called 'a war of extermination' against the IWW. ${ }^{70}$ As proof of their involvement in a 'widespread plot of the malignant reds to spread their teachings in this city', literature was collected from the homes and IWW hall of the 16 arrested individuals, which purported to show the revolutionary ideology for which they could be convicted. The most inflammatory texts collected were the little red songbooks, from which the Times drew quotes from revolutionary songs including the Internationale and Workers Marseillaise, demonstrating to the public the bloody intent they claimed was embedded within IWW culture. It was not just workers and militants that were targeted. Echoing the CFC's use of

\footnotetext{
67 'Outrages renewed. Bomb threats for Gov. Stephens', Los Angeles Times, December 27, 1917, p.1.

68 'Think New Bomb Plot of I.W.W. Discovered', Los Angeles Times, May 30, 1918

69 Horace Karr, 'Young for Fat Plums...Stephens Demands Destruction of the I.W.W.', Los Angeles Times, January 8 , 1919, p. 11.

70 'Every Red an Active Criminal, Say Authorities: Arrests Started', Los Angeles Times, October 2, 1919, p. B1.
} 
the term, the Times described one individual arrested as a 'Parlor Bolshevik', identifying him as a wealthy contributor to the group rather than an active revolutionary, a distinction that would be increasingly applied as the local war on radicalism expanded to targets beyond the working class. ${ }^{71}$ As part of their investigation undercover agents of the LAPD had infiltrated IWW headquarters in Chicago, securing the organisation's Los Angeles membership records which contained the names of over 900 IWW members in the city. ${ }^{72}$

After the success of the October operation an anti-red alliance was formed between the LAPD, the Los Angeles County Sheriff, the Los Angeles District Attorney's Office, and the American Legion. Armed with the names of local IWW members, LAPD Chief George Home oversaw an attempted cleansing of the city which began on November 15, 1919. Following Home's instructions to 'use every effort to stamp out the "Red" movement' in Los Angeles, LAPD officers broke up meetings, chased down suspects, collected evidence, and destroyed suspected radical meeting halls. ${ }^{73}$ Having called for the 'assistance of every true American in the city', local legionnaires lent their aid, forming a makeshift staging post in front of police headquarters, from where they fanned out across the city looking for evidence of suspected 'wobbly' activity. ${ }^{74}$

Though the numbers of individuals charged under the new law was initially low, and convictions even lower, Chief of Police George Home was eager to maintain the pressure on the IWW. One way he did so was through the formation of an 'anarchist and bomb squad' within the LAPD whose duties included the dedicated repression of the group. As part of this new initiative an archive of surveillance information to aid in the identification of IWW members was set-up by the same partners to the October agreement, in consultation with a 'committee composed of the leading business men of the city'. ${ }^{75}$ Perhaps as a result, Los Angeles County led the state in its attempts to avail itself of the new law over that period, thanks largely to another dragnet raid that occurred on December 14, in which the American Legion again cooperated. ${ }^{76}$ This time the LAPD focused on a pool hall near the IWW building on Spring Street, detaining 88

\footnotetext{
71 Ibid.

72 'I.W.W. Raids Made After Long Investigation', Los Angeles Times, October 2, 1919, p. B1.

73 'To Drive Reds from the City', Los Angeles Times, November 16, 1919, p. D14.

74 Ibid.

75 'Form Squad to Put Down Reds', Los Angeles Times, November 23, 1919

${ }^{76}$ Whitten, p. 53.
} 
individuals as 'suspicious characters' in what the Los Angeles Times celebrated as 'the most spectacular raid in a year' ${ }^{77}$ In what proved to be a significant precedent, the establishment of a centralised information archive on subversives taught city leaders the value of surveillance as a tool of political repression.

The crackdown in Los Angeles was simultaneous to events in eastern states, where U.S. Attorney-General A. Mitchell Palmer was also engaged in a campaign to repress unpopular segments of society. A Los Angeles Times editorial on January 5, 1920 eagerly endorsed the antiimmigrant character of these raids, arguing that the 'crude and unenlightened course of reasoning of the Russian proletariat' led inevitably to an ideological confrontation with true Americanism. The sheer number of arrests in the Palmer raids were seen as further proof of the salience of the Times' strident warnings, arguing that the 'arrest of more than 4000 persons on warrants charging them with attempting to overthrow the government by violent means is indisputable evidence of a widespread plot to Sovietize the government and industries of the country' ${ }^{78}$ Turning to local conditions, the editorial concluded that aside from the middle-class 'Parlor Bolsheviks' Los Angeles was free of reds, thanks partly to the dragnets of the city conducted by the LAPD and American egion volunteers over the last few months. The Times editorial ended with a reminder for their readers of the city's ideological inoculation against radicalism - 'in an atmosphere of industrial freedom radicalism and sovietism do not thrive'.$^{79}$

Both the national mood and the popular local application of the Criminal Syndicalism law over the winter of 1919-1920 provided Haldeman with a sympathetic public environment to relaunch the CFC as the Better America Federation, hoping to become the nucleus of a national organisation. John Randolph Haynes, a Progressive reformer and early opponent of the OtisChandler circle's control of Los Angeles observed this transformation at the end of the Liberty Bond campaign sometime in early 1920, another local patriotic drive chaired by Haldeman. At this meeting, 'Haldeman got up and said that they were starting a new organization called the Better America Federation, the purpose of which was to kill socially, politically, and economically anyone who disagreed with the tenets of the organization. These were the same

\footnotetext{
77 'Many arrested in raid', Los Angeles Times, December 14, 1919, p. A15.

78 'Can't Sovietize America', Los Angeles Times, January 5, 1920, p. B4.

79 'Can't Sovietize America', Los Angeles Times, January 5, 1920, p. B4.
} 
tenets of those of the Commercial Federation cloaked under the terms of patriotism' ${ }^{80}$ Haynes clearly recognized the BAF as another instrument of Los Angeles' militant anti-union clique, with whom he had been battling since falling out with the Times over his support of direct democracy in $1904 .^{81}$

Haynes' further recollections of Haldeman's speech from that day indicate the aggressive plans of the newly rebranded organisation for conducting surveillance in educational institutions. Haldeman told the group that the BAF would send student volunteers to 'take short-hand notes of any utterances or remarks made by fellow students, instructors, or professors at their colleges'. Informed of any inappropriate or seditious comments, the BAF would then take steps to have any teachers fired 'who had said anything detrimental to big business', though publically they would be accused of radicalism. These tactics were extended to students too-'when a student who had made a radical remark went to his home town he was seen by some influential men of the town and told to reform and get in the band-wagon. If this had no effect they were black-listed so that they could not get any positions' ${ }^{82}$ Haldeman's remarks were more than mere bluster, and indicated that he was following through on the CFC's promise to 'eradicate from the schools and colleges professors and teachers who are advocating dangerous theories of radicalism' wherever they were found. ${ }^{83}$ Upton Sinclair reported the same remarks in Goose Step, which referred to the University of California at Berkeley as the 'University of the Black Hand'. For Sinclair, the BAF's baleful influence on freedom of thought was the moral equivalent of a mafia protection racket. ${ }^{84}$

Along with the Criminal Syndicalism Bill, the other likely reason for the re-launch of the CFC as the BAF can be seen in the group's ambitions for national influence. Responding to what the Times called a 'demand' from Eastern and Mid-Western States 'that the association shall become national', Haldeman organized two meetings of patriotic groups, the first in St. Louis, Missouri, and then another in New York a few weeks later. His intention was to form state

\footnotetext{
${ }^{80}$ Letter from Haynes to B. R. Baumgardt, July 16, 1928, Box 5, JRH/UCLA.

${ }^{81}$ According to biographer Tom Sitton, a fervent patriotism was awakened in Haynes during WWI, and as a result he detested more than anything the 'hypocritical flag-waving with which the organization [the BAF] decorated its efforts to crush unions and progressive achievements'-Sitton, John Randolph Haynes, p. 155.

82 Letter from Haynes to B. R. Baumgardt, July 16, 1928, Box 5, JRH/UCLA.

83 'Pasadena Declares Labor Union A Peril', Los Angeles Times, March 2, 1920, p. A2.

84 Upton Sinclair, The Goose-Step: A study of American education, (Pasadena: Upton Sinclair, 1923), pp. 121-3.
} 
chapters of a new Commercial Federation with a national reach, a plan enthusiastically endorsed by the Times who credited the group with 'freeing Southern California from the tyranny of the labor unions' ${ }^{85}$ At least one contemporary critic of the CFC noticed this national power play, though he speculated that the real purpose was to confer with leaders of some secret national organization already meeting. ${ }^{86}$

While a follow-up report in the Times indicates that the St. Louis meeting was a success for the CFC, New York's anti-radical groups were somewhat more reluctant to take direction from California, perhaps confirming that an established organisation was indeed active..$^{87}$ The meeting did however lead to information sharing between the patriotic groups as the BAF's weekly letters to subscribers demonstrate. These included references to 'advices from Washington' and 'sources of secret information available' only to BAF subscribers via the Weekly Letter. ${ }^{88}$ Though they had been blocked in their goal to become a national organisation, the CFC's reincarnation as the Better America Federation was an auspicious moment, heralding the beginning of a California surveillance network which would deliver their message to the national audience that Haldeman and his allies sought.

\section{A Better America through the Open Shop}

There was no doubting who was in charge of the BAF in its early years, with its centralised structure servicing Haldeman's distaste for democracy. Ultimate power over the organisation was wielded through an executive committee composed of bureau heads, and chaired by Haldeman himself-ironically a structure which replicated the compartmentalisation of the conspiratorial it had ostensibly been set up to combat. This new organisation set itself two key goals: 'to suppress unionism wherever it is active', which it labelled the fight against 'Bolshevism'; and 'to weaken or abolish government regulation of business', as it described the fight against 'Socialism'. Setting up its own anti-communist

\footnotetext{
85 'Commercial Federation', Los Angeles Times, Mar 1, 1920, p. B4.

${ }^{86}$ Hopkins, p.11.

87 'Form Organization to Combat Radicalism', Los Angeles Times, March 3, 1920, p. A1.

88 Hopkins, p.11.
} 
nomenclature, the BAF presented itself as defending 'Patriotism' and '100\% Americanism' against un-American ideas in a prefiguration of the use of the concept by later investigative committees ${ }^{89}$ In addition to conducting surveillance to pursue these goals, the BAF was also active developing an ideology to gain adherents and to accuse the targets of its surveillance of being unpatriotic.

The BAF officially adopted the new name on its subscriber-only publications on May 11 1920. Setting a pattern of cause and effect that would be applied continuously in following years, the first publication under the new masthead opened with a denunciation of the IWW 'One Big Union' movement, claiming that recent strikes among railway workers were the result of IWW infiltration into the railway brotherhoods. Claiming that the brotherhoods would soon be affiliating with the moderate American Federation of Labor [AFL], the BAF author concluded that there existed an IWW plot to drag the AFL into the railway strikes, thereby trapping them within an unwinnable dispute which would induce a general strike and, it is implied, ultimately a revolution..${ }^{90}$ By thus framing any kind of industrial dispute as the product of radical infiltration the BAF sought to deny the legitimacy of the strike as a tool of organised labour.

The second article discussed radicalism in the churches. Dismissing a recent public statement from a Methodist organisation that 'the great church organizations of this country' favoured collective bargaining and the nationalisation of industry, the article instead concluded that this was an unauthorized attempt to present the Methodist churches as more sympathetic to socialist principles than was really the case. ${ }^{91}$ This would seem an uncharacteristically optimistic diagnosis from the BAF were it not for the campaign their predecessors the CFC had been waging against the Los Angeles Young Women's Christian Association [YWCA] for the previous month - a campaign that required the Methodist 'social creed' to be represented as the ideology of a radical fringe.

The BAF immediately made continuing this campaign one of its debut acts as a 'new' patriotic organisation. Already the CFC had attacked in print the YWCA for endorsing the

\footnotetext{
${ }^{89}$ Hopkins, p. 9; The House Un-American Activities Committee (HUAC) is only the most famous of a series of committees to borrow the term.

90 Better America Federation, Weekly Letter, No. 47, May 11, 1920, Box 6, JRH/UCLA.

${ }^{91}$ Better America Federation, Weekly Letter, No. 47, May 11, 1920, Box 6, JRH/UCLA.
} 
Methodist social creed-a platform for social and industrial justice which among its provisions acknowledged the right to collective bargaining. ${ }^{92}$ Over the next month as the CFC began its official transition into the BAF the attacks continued unabated, lambasting the YWCA in regular published updates on 'Radicalism and the Churches'. The YWCA's stance was particularly irksome, argued one article, 'in view of the fact' that the group 'is appealing to business men and employers in its campaign for funds' at a time 'when we see the greatest unions in the country, the Four Brotherhoods, unable to control their members and therefore unable to keep the agreements into which they themselves have entered'. ${ }^{93}$ Seizing on the connection between financial support and ideological compliance, Haldeman wrote a series of letters to the YWCA's financial donors in Los Angeles, urging them to withdraw financial support from the organisation. Beginning his letter with the martial warning that 'business men will refuse to supply ammunition with which they are to be shot', Haldeman's letters sought to convince the business community that an endorsement of the social creed equated to a declaration of war against employers who supported the open shop, as all 'right-thinking' Los Angeles employers $\operatorname{did} .^{94}$

Haldeman's intervention clearly had an effect, for in the days following its transmission several firms in addition to his own plumbing business, the Pacific Pipe Supply Co., withdrew financial support from the Los Angeles YWCA. Damage done to the YWCA by June 1920 amounted to $\$ 2700$ in lost funding, a substantial amount of money for a non-profit group at that time. ${ }^{95}$ In response a YWCA delegation visited Haldeman to protest several misrepresentations of fact in his letter to their sponsors, and to request the public retraction of his statements. After a series of communications back and forth between the two groups, and several broken promises from Haldeman, the YWCA had come no closer to redress for what they saw as an unfair misrepresentation of the YWCA's social position accompanied by a direct attack on their major sources of financial support.

\footnotetext{
92 Better America Federation, Weekly Letter, No. 41, March 30, 1920, Box 6, JRH/UCLA. The 1908 social creed also favoured the adoption of a number of other progressive ideals, including the abolition of child labour, strengthening of workplace safety laws, equal rights among citizens irrespective of race or gender, sensible working hours, and the equitable distribution of profits.

${ }^{93}$ Better America Federation, Weekly Letter, No. 46, May 7, 1920, Box 6, JRH/UCLA; National Founders Association, Weekly Letter, No. 118, April 29, 1920, Box 6, JRH/UCLA.

${ }^{94}$ Harry M. Haldeman, Transcript of form letter to YWCA subscribers, May 7, 1920, Box 6, JRH/UCLA.

${ }^{95}$ Correspondence from John Haynes to Governor William Stephens, June 16, 1920, Box 5, JRH/UCLA.
} 
The BAF's attack on the YWCA in Los Angeles is interesting for several reasons. For one, it demonstrates the degree of social and economic pressure which the BAF could employ to enforce ideological compliance. Secondly, it demonstrates how such pressure could be applied through back-door contact amongst members of the business community. The incident generated substantial controversy, and a report on the incident to the State Commission of Immigration \& Housing noted that 'naturally many of the [YWCA] women are afraid of the influence of Better America upon their husband's business affairs'. This put several nervous YWCA board members in the awkward position of feeling trapped by a binding national resolution passed by their organisation that nevertheless carried direct personal costs. ${ }^{96}$ The episode shows that the BAF had assigned itself a specific punitive function within the Los Angeles business community, and that was the repression of social and economic dogma inimical to its interests. Like much of the Los Angeles business community, these interests were centred on the maintenance of the open shop.

As was the case with the YWCA, the BAF also exerted significant financial pressure to isolate Los Angeles employers who refused to join the ranks and support the open shop. Haynes, who had experienced similar tactics during his clashes with Otis and Chandler, explained the BAF's methods: 'Business men who refused to join [the BAF] at first request were seen by a "higher up", and told that it would be "bad business" not to join, and many joined under the force of this argument. One man who had a great many employees refused to take out a membership on the plea that he did not see the necessity for such an organisation. Within 48 hours of his refusal he recalled the solicitor and handed him a full list of his employees, numbering about fifty, as members at $\$ 5.00$ per. Word had reached him that it would not be to his business interest to refuse' ${ }^{97}$ Though the BAF frequently championed 'industrial freedom' for workers, they were clearly not inclined to allow Los Angeles' employers the freedom to determine their own associations.

To coincide with the debut of the new organisation BAF leaders launched a membership drive with the aid of the Los Angeles Times, which promoted it as a 'patriotic message of service to the nation and active opposition to the radical propaganda' that was being put forth by

\footnotetext{
${ }^{96}$ Hopkins, Box 6, JRH/UCLA.

97 John R Haynes to Senator Hiram Johnson, no date, Box 5, JRH/UCLA.
} 
organisations like the IWW. BAF membership at that time was reported to be around 10,000 individuals, and the hope was that the drive would bring in 25,000 new members. ${ }^{98}$ To accomplish this ambitious goal the BAF formed campaign committees to pound pavements, targeted individuals with mail appeals, and advertised in motion picture theatres. Enthusiastic coverage in the Times granted Haldeman and his colleagues a public platform for their appeals decrying the precarious state of American society. According to one public appeal there were '35,000 Reds who are on the radical payroll' in the country, opposed only by 2000 patriotic individuals such as himself willing to call a halt to the 'Russianization' of the United States. ${ }^{99}$ Given that the BAF had claimed a membership of 10,000 only a few days earlier, it seems that Haldeman must have doubted the commitment of some BAF members to the organisation's patriotic ideals.

Despite its best efforts to capitalise on public anti-radical sentiment, the Los Angeles Times never reported on the conclusion of the membership drive, and it seems likely given the absence of a declaration of success that the organisation had failed to reach its goal. Frustration at the lack of enthusiasm shown by the public to their strident warnings was a regular feature of BAF publications. In a June 1920 letter the BAF warned its readers of the consequences of a general slackening of the nation's patriotic posture, claiming that 'the red forces of Europe have taken note of this apathy on the part of the public of this country to things political' and so 'are taking advantage of the unorganized public opinion to make revolutions while the sun shines'. ${ }^{100}$ BAF window placards around Los Angeles made similar appeals, urging citizens to join the cause - 'Bolshevism is the prescription of despair. Good citizens will not tolerate it', 'You would die for America, why not LIVE for America? Join the Better America Federation', and 'America is suffering from the bad citizenship of a lot of good people'. ${ }^{101}$ While the businessmen in whose windows these signs appeared were doing what was required of them, the public reception to the BAF's continuing 'Americanism' campaigns seems to have been lukewarm.

\footnotetext{
98 'Better Americanism Campaign on Here', Los Angeles Times, May 23, 1920, p. B3.

99 'Better Americanism is Campaign Slogan', Los Angeles Times, May 26, 1920, p. A15. These alarming figures were given to Haldeman from a 'Col. French' of the Greater lowa Association, as recorded in Commercial Federation of California, 'Why radicalism Spreads', Weekly Letter, No. 43, April 12, 1920, Box 6, JRH/UCLA. The source of Col. French's information is unclear, though the article records that it 'has not been made public'.

100 Better America Federation, Weekly Letter, No. 50, June 2, 1920, Box 6, JRH/UCLA.

101 Hopkins, Box 6, JRH/UCLA.
} 
Many BAF members continued their involvement with the Association for the Betterment of Public Service after the reorganisation, which continued to endorse candidates for state and local office. Chaired by Haldeman, the ABPS's campaign committee promoted candidates in the 1920 Republican primaries for the state legislature with a platform based on action against the 'deadly menace of organized and subsidized propaganda for the overthrow of our present form of government'. This promise was contextualised with the claim that the previous decade's reformist murmurs were the product of 'propagandists of class consciousness and favoritism'. ABPS-endorsed candidates that year included the incumbent State Senator Harry Chamberlin \& a new candidate for the State Assembly, Willard E. Badham, both of whom fit their requirement for representatives 'unafraid to incur the enmity of the professional politicians and class lobbyists' ${ }^{102}$ Both candidates were successful in their campaigns. ${ }^{103}$ In the publications of the BAF and its affiliates, 'class' was an contemptuous construct, used to refer to the prejudices of unions or working-class voters, and one devoid of any notion of a business class to which BAF members belonged.

However, the BAF didn't hesitate to utilize class privileges in service of its own goals. A report in the San Francisco Call in 1922 described the BAF's recruitment of 'the children of the best business families' to conduct surveillance on 'students of radical tendencies' who they studied with. These progenies of the wealthy Californian elite would then compile 'reports of what is going on, both as to students and teachers that uphold radical doctrines and views', and then sent to BAF headquarters, likely to be used for the development of educational blacklists. ${ }^{104}$ An article in the Los Angeles Times describing the BAF's investigations of a nefarious 'plot' to organize Los Angeles educators confirms that the group was particularly worried about labour unions in education. After discovering attempts by 'agents' of the California State Federation of Teachers to persuade teachers to join their union, the BAF obtained the identities of teachers who had expressed interest. These names were passed to the school authorities, who were pressured to take disciplinary action. ${ }^{105}$ The BAF also targeted teachers and students directly,

\footnotetext{
${ }^{102}$ Association for the Betterment of Public Service, Principles and Purposes of the Association for Betterment of Public Service, c. July 1920, Box 6, JRH/UCLA.

${ }^{103}$ Chamberlin represented the 31st State Senate district until 1928, while Badham represented the 72 nd district in the state assembly, a post he held until 1930.

${ }^{104}$ Upton Sinclair, The Goose-step, pp.129-131.

105 'Plot New Union of Teachers', Los Angeles Times, January 12, 1922, p. A1.
} 
placing issues of The Commonwealth each week in the mailboxes of teachers in the public schools, and likewise attempted to insert anti-labour propaganda into the school curriculum. ${ }^{106}$ One of these publications, 'America is Calling', was the subject of a hearing before the California State Board of Education, where the BAF was forced to explain its attempts to indoctrinate Californian schools with the BAF's social and economic views. ${ }^{107}$

California's direct democracy laws were another target of the BAF, which the organisation recognised as a potential obstacle to its lobbying and political activities. By introducing the initiative, referendum and recall onto the ballot at both the state and city level, direct democracy campaigners (including John Haynes, also a keen-eyed critic of the BAF) sought to direct the legislative agenda via popular participation, an anathema to the elitist plutocrats of the BAF. During a dinner at Los Angeles' exclusive Jonathan Club, BAF speaker Harry F. Atwood brought the organisation's typical rhetorical tactics to bear on direct democracy, claiming that 'the fathers of our country were more fearful of democracy than of autocracy', likening California's citizen participation to that of Soviet Russia. Perhaps inadvertently over-revealing the BAF's conception of its role in California politics, Atwood remarked that 'in baseball as in government if the umpire's decisions are bad we have only one thing to do, remove him and put in another umpire in the next inning ${ }^{\prime} .{ }^{108}$

Haynes was sufficiently alarmed by the BAF's activities by this point to write to U.S. Senator Hiram Johnson with a warning, hoping that Johnson's influence could check their spread. His letter suggests Haynes was aware of their national ambitions, describing them as 'a very serious menace to advancement in government in California and in the United States' as a whole. ${ }^{109}$ Though Governor Stephens had agreed with the BAF on the issue of the Criminal Syndicalism Bill, by 1921 he too had become wary of the group. Bemoaning their lobbying activities in Sacramento, Stephens complained that:

\footnotetext{
${ }^{106}$ Haynes reported this public relations effort as a note scrawled on a copy of one of their publications-Better America Federation, The Commonwealth, Vol. 3, No. 8, May 1920, Box 5, JRH/UCLA.

107 Report of hearings of representatives of Better America Federation before the State Board of Education, March 28, 1921, Box 6, JRH/UCLA.

108 'Says rule by public is failure', Los Angeles Times, December 16, 1921, p. B6.

109 John R Haynes to Senator Hiram Johnson, no date, Box 5, JRH/UCLA.
} 
'the 13 members of the last session of the legislature who attacked the administration have been openly and completely subservient to the Better America Federation [...] behind these 13 willing tools masquerade the representatives of those special interests which seek to dictate appointments on the railroad commission and direct its policies, to have a part in the selection of judges in our courts and to gain such dominance over the various agencies of government as can serve the advantage and profit of those who seek to exploit our state [...] it is a huge money-making enterprise, for if they can fix rates, obtain special privileges, as they may desire them, exert influences over the railroad commission and other functions of government, their gains would run into untold millions' ${ }^{110}$

Warning of their future influence, Stephens also repeated a BAF boast about a $\$ 1,000,000$ campaign fund to spend in next year's election, which had allegedly been contributed by Harry Chandler of the Times. ${ }^{111}$ Perhaps the boast was accurate, as Stephens lost the primary the following year to a more conservative Republican candidate. Haynes' biographer Tom Sitton concurred with Stephens' appraisal of the group's influence, noting that Katherine P. Edson, a local civic leader, complained that 'even the judges are crawling to their chairman, Mr. Harry Haldeman, and explaining why they make the decisions they do'. ${ }^{112}$ Progressives like Haynes, Edson, and Stephens clearly felt that the BAF's power was used for self-interested purposes by the business clique that dominated Los Angeles' city government and economic life, and the state Republican party in which they played a powerful role.

As Haynes had warned, evidence suggests that from its foundation the BAF's sphere of interest reached beyond California's borders. From March 23 to May 12, 1920, immediately before the name change to the BAF, the CFC's Weekly Letter contained only 18 articles on

\footnotetext{
${ }^{110}$ Anon. 'Governor Stephens Charges Million Dollar Slush Fund', Los Angeles Record, December 5, 1921, Box 5, JRH/UCLA. Stephens claims that the 13 legislators beholden to the BAF were Joseph Pedrotti, Harry A. Chamberlin, H. H. Yonkin, W. E. Badham, R. P. Benton, Harry Lyons, Sidney T. Graves and Elmer P. Bromley, all of Los Angeles; J. A. Rominger and Frank A. Merriam of Long Beach; Charles W. Lyon of Venice Beach; James O. Bishop of San Diego, and W. F. Beal of Imperial County. As noted above, Chamberlin \& Badham were endorsed by Haldeman and the BAF (as the ABPS) in the 1920 Republican primaries. Merriam would later become governor of California in 1934, just as the maritime strikes of San Francisco were escalating. Later that year he defeated Upton Sinclair to retain the governorship in one of the most fiercely contested elections in Californian history.

111 Ibid.

112 Sitton, John Randolph Haynes, p. 155.
} 
California out of 65 total, with the vast majority national or international in scope. A similar observation led a contemporary observer to conclude that the BAF had a national source supplying some of the information in their publications. ${ }^{113}$ Another employers' group called the National Founders' Association was the likely source of that information in 1920, as at that point the information printed in the BAF's Weekly Letter to subscribers was dominated by labour, economic, and industry news, and bore few traces of the surveillance activities it would develop later.

In subsequent years the BAF established connections with a national patriotic network which included groups such as the American Defense Association, the American Vigilant Intelligence Federation, and the Daughters of the American Revolution, exchanging newsletters, speakers, and other forms of communication with the BAF. In 1924 the BAF resumed attempts to forge a national organisation, attending an 'All-Americanism Conference' of sixty-two patriotic organisations which met in Washington, D.C. to consider the best means of overcoming subversive activities and radical movements'. At the conference the BAF helped craft a number of national resolutions condemning 'sinister and widespread propaganda', and affirming a commitment that 'every educational and publicity channel be used to expose disloyalty and revolutionary radicalism [...] parading falsely under the name of pacifism'. Further resolutions deplored the invasion of American schools by radical educations, and branded as 'un-American' criticisms of the possibility that the United States might 'resort to arms in defense of justice and self government' against the Soviet Union and her agents. ${ }^{114}$

Information and prejudices exchanged with these national contacts soon made their way into the BAF's regular publications. In what the BAF proposed as an 'antidote for pacifism', the Weekly Letter of July 22, 1924 reported on the efforts of an Episcopalian bishop in Massachusetts who had developed a pledge which he planned to circulate to pacifist 'churches and other bodies in opposition to war', and he hoped they would adopt. This pledge would entreat pacifists who renounced violence to also renounce their citizenship of the United States, and to then 'seek some other country from which [they] may obtain something from nothing, or at the

\footnotetext{
113 Hopkins, Box 6, JRH/UCLA, p.1.

${ }^{114}$ Report on National Americanism Conference, May 17, 1924, Box 6, JRH/UCLA; 'Renews Battle on Red Menace', Los Angeles Times, July 13, 1924, p. A6.
} 
cost of the blood and treasure of other people'. ${ }^{115}$ Another valuable supplier of information to the BAF encountered at the conference was Fred Marvin, whose pamphlets were regularly published by the BAF after 1924. Marvin had played a role as the author of numerous exposes of radical conspiracies for the New York Commercial and then the Key Men of America. ${ }^{116}$

BAF publications also record their opposition to officially legitimate expressions of leftism, such as the fledgling Farmer-Labor Party, which it described as a 'catch-all' for 'Reds, Pinks and Liberals', suggesting the expanding categories of suspicion that they were applying to their opponents. Several planks of the party that the BAF opposed were reasonable and took the form of proposed constitutional amendments, such as veto power for congress over Supreme Court decisions, and the direct election of Federal Judges. Others had civil rights, radical or anti-militarist foundations, such as the repeal of Criminal Syndicalism laws, the abolition of military training in public education, the release of IWW prisoners, and the recognition of Soviet Russia. ${ }^{117}$

In the BAF's interpretation reform was conflated with revolution. Socialism and Communism, argued the BAF, were known to be illusions even to their proponents, since mankind was plainly not a smooth mass of individuals but a seething lump of contradiction and variation. Communism could never work they argued, because 'the illiterate, the physically

and morally deficient have never dwelt together in harmony with, nor can they reduce the higher types of mankind to a common level'. ${ }^{118}$ With these weekly missives sent to out to their subscribers the BAF developed and propounded an evolving critique of current events around the nation and the world, instructing their readers in 'true' patriotic thought. Most of the BAF's attention, however, remained focused on Los Angeles where it continued to stir up controversy through its open-shop propagandizing and increasingly, its surveillance work.

\footnotetext{
${ }^{115}$ Better America Federation, Weekly Letter, July 22, 1924, No. 266, Box 6, JRH/UCLA.

${ }^{116}$ See Fred Marvin, Bootlegging Mind Poison, New York, n.d. (c. 1924), Box 6, JRH/UCLA; the pamphlet links the establishment of the 'Order of the Illuminati' in $18^{\text {th }}$ century Bavaria to the Bolshevik conspiracy, both of which groups supposedly favoured the destruction of Christian civilization. The anti-Semitism underlying this connection is barely concealed.

117 Better America Federation, Weekly Letter, July 29, 1924, No. 267, Box 6, JRH/UCLA.

${ }^{118}$ Better America Federation, Weekly Letter, November 4, 1924, No. 281, Box 6, JRH/UCLA.
} 


\section{Enforcing the Open Shop}

Between 1921 and 1923, IWW members on the San Pedro docks were increasingly active among longshoreman and sailors, who they hoped to entice to their movement. According to specialist studies of the strikes, the San Pedro docks were far from a natural hotbed for militant unionism, and indeed had previously been 'conspicuously free of even orthodox union activity'. ${ }^{119}$ This changed as a post-war shipping slump slowly wound down commerce along the California coast, pressuring both employers and workers to make the most of the limited trade available. As workers began organizing, ship owners and port officials responded by introducing employer-run hiring halls and other measures to disrupt the membership of the moderate International Seamen's Union and the International Longshoreman's Association. The ensuing drama captured the attention of Los Angeles, and the situation that unfolded on the waterfront was undoubtedly the high point of industrial conflict in the city during the early 1920s.

Throughout 1921 the IWW targeted San Pedro as a harbour which the slump had rendered more receptive to their aims, holding a series of mass meetings to induce dock workers and sailors to forego their previous associations and instead join militant organisations like the Marine Transport Workers' Industrial Union. In late 1922 the situation escalated sharply after a police raid on November 8 led to the arrests of 36 IWW members on charges of Criminal Syndicalism, in which future LAPD Intelligence Bureau officer Luke Lane took a leading role. ${ }^{120}$ After a series of similar police crackdowns in other areas throughout California and up the West Coast, the IWW leadership felt compelled to respond. They did so by urging all IWW members not already settled to head to San Pedro, with the intention of forcing a confrontation at the docks. Welcoming the looming violence, Los Angeles Chief of Police Louis Oaks declared 'Let 'em come. We've got plenty of rock piles here'. ${ }^{121}$

\footnotetext{
${ }^{119}$ Nelson Van Valen, "Cleaning Up The Harbor': The Suppression of the I.W.W. at San Pedro, 1922-1925', Southern California Quarterly, Vol. 66, No. 2, 1984, p. 147.

120 'Thirty-Six Reds Seized in Police Harbor Raids', Los Angeles Times, November 9, 1922, p. B1.

121 'Harbor Guards Doubled’, Los Angeles Times, November 22, 1922, p. B1.
} 
As waves of 'footloose' IWW members began flowing into San Pedro Chief Oaks made good on his threat, taking direct control of policing the harbour from local authorities and launching a new series of anti-radical raids in the harbour district. The largest occurred on December 19 1922, when an IWW meeting in San Pedro was stormed and 75 members arrested on charges of Criminal Syndicalism. ${ }^{122}$ The next day the Times reported the formation of a police 'Wobbly Squad' led by Luke Lane to deal with the continuing stream of radicals coming to San Pedro. ${ }^{123}$ Despite mass arrests of the IWW rank and file the group was able to solidify their position over the next few months, and arrests slowed down while local membership increased to somewhere over 500. ${ }^{124}$ Finally the call to strike was issued on April 25, 1923, and within the first week workers had succeeded in causing a deadlock at the docks, with over sixty vessels tied up and unable to unload. The Shipowners' Association of the Pacific Coast responded by bringing in 200 non-union men to replace the striking workers, and despite IWW assurances of a non-violent strike, arranged for the strike-breakers to be escorted by guards from the Eleventh Naval District in San Diego. ${ }^{125}$ The police provided further protection by arresting all pickets as they formed as well as anybody caught distributing strike literature.

As the strike continued into May additional police were brought in to enforce the increasingly stringent restrictions on free speech and the use of public space. A Times editorial in mid-May summarised the situation in lurid terms - 'Los Angeles must be either red or white. For four years it has been the white spot on the commercial and industrial map of the country. The Reds seek to blacken it with smoke and redden it with blood [...] While these Reds are free and active the freedom and security of all other citizens is threatened'. ${ }^{126}$ That same day the largest anti-IWW mass arrests ever seen in California were launched, resulting in the detention of almost 400 individuals but very few convictions. Railway containers from Pacific Electric were brought in to transport the detainees from San Pedro to the Lincoln Heights Jail in Los Angeles. The Times called it 'the greatest campaign against Reds ever made in the United States', but warned of new developments such as the arrival in San Pedro of 'Big Rosy' and his

\footnotetext{
122 'Record Haul of Reds Caught in Harbor net', Los Angeles Times, December 19, 1922, p. B1.

123 'Clean-up of Harbor Reds is Promised', Los Angeles Times, December 20, 1922, p. B1.

${ }^{124}$ Nelson Van Valen, "Cleaning Up The Harbor': The Suppression of the I.W.W. at San Pedro, 1922-1925', Southern California Quarterly, Vol. 66, No. 2, 1984, pp. 151-152.

125 'Shipowners to Defy Strikers', Los Angeles Times, May 5, 1923, p. B1.

126 'Reds at the Harbor', Los Angeles Times, May 14, 1923, p. B4.
} 
'phosphorus squad', who were supposedly about to begin a campaign of arson in the harbour. ${ }^{127}$ With the jails overflowing in both San Pedro and Los Angeles, city councillors considered the construction of a stockade in Griffith Park to house them all.

After the mass arrests of May 14, 1923 the strike swiftly collapsed. Out of solidarity for the strikers Upton Sinclair staged a free speech protest the following night on Liberty Hill, the popular heart and political forum of the IWW strike in San Pedro. After first informing San Pedro police of his intentions, Sinclair and a small coterie of fellow 'Parlour Pinks" proceeded towards Liberty Hill, flanked by policemen under the command of Police Chief Oaks, who had assured Sinclair he would be arrested if he didn't 'cut out that constitution stuff'. ${ }^{128}$ Oaks again made good on his threat, and Sinclair and four of his companions were arrested after Sinclair ascended Liberty Hill and began reading the first amendment to the constitution of the United States. After a 24 hour period of being shuttled around the city's various jails, the men were arraigned in Los Angeles court and each formally charged with conspiracy to commit a crime. ${ }^{129}$

Such displays of solidarity were unable to change the conditions on the docks, and the strikers gradually began returning to work. Between constant raids by San Pedro and Los Angeles police and the importation of hundreds of strike-breakers by the Shipowners' Association, the IWW simply lacked the presence in San Pedro to continue. Though they issued a renewed strike call in July in protest at the conviction of 27 of their members for Criminal Syndicalism, it failed to gain significant support and quickly fizzled out. On New Year's Day in 1924, a Times editorial reported breezily that Los Angeles' open shop was safe once again - 'Los Angeles is blessed with industrial freedom, and therefore not afflicted with the labor troubles that have harassed and hampered many other cities. There is incentive here to work and to produce, and in this there is no molestation by outside 'bosses'. Here is exemplified the wisdom of maintaining the independence of labor. The employer, the employee and the community are

\footnotetext{
127 'Raids on Wobbly Nest at Harbor Net 300 Reds', Los Angeles Times, May 15, 1923, p. B1.

${ }^{128}$ Hunter Kimbrough, 'Cut Out That Constitution Stuff', Haldeman-Julius Weekly, 1923, quoted in Martin Zanger, 'Politics of Confrontation: Upton Sinclair and the Launching of the ACLU in Southern California', Pacific Historical Review, Vol. 38, No. 4, November 1969, pp. 383-406.

129 'Sinclair Held for Trial', Los Angeles Times, May 17, 1923, p. B1; For an even-handed account of Sinclair's protest and his subsequent involvement in setting up the Southern California ACLU, see 'Martin Zanger, 'Politics of Confrontation: Upton Sinclair and the Launching of the ACLU in Southern California', Pacific Historical Review, Vol. 38, No. 4, November 1969, pp. 383-406.
} 
beneficiaries'. ${ }^{130}$ It was almost as if the unrest in San Pedro of the previous year had never taken place.

At an annual banquet of the Merchants \& Manufacturers Association held on January 28, 1924 the President of the organisation Irwin Rice took credit for ending the strike of the previous May. Calling it just another 'typical "wobbly revolution"', Rice denied that the situation was really a strike at all. According to his account the $M \& M$ and their enforcers were brought in at the behest of the ship owners-'After an almost complete tieup of the water front for several weeks, during which time over sixty unloaded vessels accumulated in the harbor, an appeal was made to this association by a representative of the shipping interests from San Francisco. It was our pleasure to take hold of the situation and, with the splendid co-operation of the police, the trouble was broken within a week'. ${ }^{131}$ By insisting the strike was an attempted revolution that could best be dealt with by the combined force of employers and the LAPD, Rice was offering a condensed account of the process of repression followed in Los Angeles since 1917, and a model for a way for future organisations to exploit public hysteria to discipline labour.

Despite the M\&M's self-aggrandizing claims of having busted the 'wobbly revolution', violence against the IWW in San Pedro continued through 1924. The prime factor in the final dispensation of violence against the IWW seems to have been the appointment of Captain W. L. Hagenbaugh as the officer in charge of San Pedro Police, along with his deputy Sergeant Webber. From March 1924 onwards Hagenbaugh and Webber issued a series of encouraging incitements to citizens aggrieved by the IWW presence, publically claiming neutrality in any future confrontation that might eventuate between citizens and IWW, while privately offering tacit approval to any vigilante actions that might ensue. Sure enough, following several intimidating public demonstrations by the Klu Klux Klan an all-out vigilante attack on the IWW hall in the harbour was mounted in June 1924. The spark was supposedly struck by what the

\footnotetext{
${ }^{130}$ Myrtle Gebhart, 'Mightiest Strides Here Through Past Year', Los Angeles Times, January 1, 1924, p. H2.

131 'Merchants \& Manufacturers Association Gathers for Annual Dinner at Biltmore Hotel', Los Angeles Times, January 29, 1924, p. A1; Upton Sinclair corroborated this story, claiming to have overheard the appeal for help while in Rice's office on an unrelated matter - Upton Sinclair, 'We Get Arrested', The Liberator, No. 63, July 1923, pp.16-22, quoted in Martin Zanger, 'Politics of Confrontation: Upton Sinclair and the Launching of the ACLU in Southern California', Pacific Historical Review, Vol. 38, No. 4, November 1969, pp. 389-390.
} 
Times asserted were 'open sneers by Wobblies' over a shipboard accident which cost the lives of 48 navy sailors, a rumour undoubtedly circulated to inflame sentiment against the IWW. ${ }^{132}$

The perpetrators of the assault numbered somewhere close to 100, split into four groups, who proceeded in an organized way to utterly demolish everything inside the hall. The details of what else transpired are disputed, but what is incontestable is that as men, women and children scrambled for safety, an urn of boiling coffee was overturned, and at least two small children were badly burned. ${ }^{133}$ According to the chairman of the IWW fundraising meeting that was then using the hall, victims were driven from the hall past burning furniture, beaten as they went, to where the mob had prepared a large bonfire outside. As the terrified IWWs and their friends scattered into the night nine of the IWW leaders were forced into trucks and driven out to the Santa Ana Canyon east of the city, where they were beaten, robbed, stripped naked, and finally tarred and feathered. ${ }^{134}$

There is little doubt that elements of the San Pedro police conspired with the mob to not intervene. A detail of police assigned to protect the hall from vigilantes were called away by officers just before the attack under pretences that turned out to be false, while victims identified Police Sergeant Webber among the group of KKK, revenge-seeking sailors and local elks among the participants. ${ }^{135}$ Though traces of an IWW presence remained in San Pedro and arrests continued sporadically, the fight was essentially over. After 1925 the IWW ceased to make headlines in San Pedro.

\section{Documenting Dissent}

Despite the public zeal displayed in their pursuit of IWW members and other radicals, during the six month period from October 1919 to March 1920 only sixty-three indictments were handed down by grand juries across California on charges of Criminal Syndicalism. This

\footnotetext{
132 'Port Wobblies Tarred, Charge', Los Angeles Times, June 16, 1924, p. A1.

133 'Sailors wreck Wobblies Hall', Los Angeles Times, June 15, 1924.

134 'Port Wobblies Tarred, Charge', Los Angeles Times, June 16, 1924, p. A1.

135 'Sailors wreck Wobblies Hall', Los Angeles Times, June 15, 1924, p. 4.
} 
included the November arrest and January trial of Charlotte Anita Whitney, a local member of the Communist Labor Party whose conviction and subsequent appeals made her a symbol of a national campaign for repeal of Criminal Syndicalism laws. California prosecutions under the CS law didn't peak until the rush of 'footloose' IWW members to San Pedro, which resulted in one hundred and sixteen indictments between October and the end of $1922 .{ }^{136}$ In many ways San Pedro represented the end of the first period of repression under the Criminal Syndicalism Law in California. The atmosphere of the 'red scare' was diminishing, and after San Pedro Californian juries developed a reluctance to convict under the membership provisions of Criminal Syndicalism that had previously been used to break the back of the IWW movement. The reason given by one commentator was the refusal by jurors to convict IWW members 'on the ridiculous falsehoods of the self-confessed criminals whom the prosecutors have been in the habit of using as their chief witnesses' ${ }^{137}$

Partly as a result of these difficulties Judge Charles O. Busick issued a blanket injunction against all current and future members of the IWW which legally restrained them from violating the provisions of the Criminal Syndicalism Act. Armed with this legal mechanism, police officers could arrest any IWW member they encountered on the misdemeanour charge of violating a court order (the Busick injunction) that restrained them from conspiring to commit Criminal Syndicalism; the Machiavellian logic underlying this legal strategy was somehow constitutional according to a decision by the California Supreme Court in $1924 .{ }^{138}$ With the Busick injunction in place there was a reduced need for costly or potentially exonerating jury trails, since it allowed law enforcement to jail IWW members whenever they posed enough of a threat to justify their further repression. After 1925, they seldom did.

Though the IWW in California had been effectively disrupted with the use of the Criminal Syndicalism law and then the Busick injunction, new radical threats were emerging. Over the course of the 1920s the CPUSA had been steadily expanding its membership, both underground and through the Workers Party of America. Despite the urgent threat patriotic groups claimed the CP represented, in 1924 U.S. Attorney General Harlan F. Stone ordered an end to the

\footnotetext{
${ }^{136}$ Whitten, p. 54.

${ }^{137}$ Quoted in Whitten, p. 58.

${ }^{138}$ For a full discussion of the history and implications of the Busick injunction, see Whitten, pp. 58-6 .
} 
fledgling countersubversive activities then being undertaken by the Bureau of Intelligence, reportedly because of the inadequacy of federal laws and a lack of funds to pursue investigations. ${ }^{139}$ The following year the fifth world congress of the Comintern decided that the conditions for revolution in the United States were not favourable, and instructed the CPUSA to instead work towards engaging with labour unions, winning political allies and joining with other leftist organisations in a campaign of infiltration and consolidation. The ascendance of the CPUSA as a significant political force in California was about to begin.

The BAF had paid attention to both of these developments, and in the absence of a federal programme began instituting its own surveillance programs tracking CP efforts to 'bore within' and radicalise American society. In June 1925 they summed up the situation by connecting the various parts of the conspiracy they saw at the heart of the nation, citing 'one thousand publications [...] openly or covertly advocating communism', 'thousands of boys and girls organized into the Youth Movement, and incited to rebellion', and 'millions of declared Socialists and Communists ceaselessly agitating the abandonment of our form of government'. ${ }^{140}$ The BAF named the American Civil Liberties Union as protectors of this conspiracy, reporting a statement made by ACLU director Roger Baldwin that the organisation stood for 'the right of persons to advocate the overthrow of government by force or violence', a key plank of the Criminal Syndicalism laws it opposed. ${ }^{141}$

In October the BAF offices at 724 South Spring St Los Angeles were broken into on the night or early morning by unknown persons. Calling the group 'one of the greatest single bulwarks against the spread of revolutionary principles', the Times quoted BAF manager Joe Joplin as saying that the records stolen might reveal the activities of radical groups but not the sources of the information. As surmised by the BAF, the break-in attested to the existence of groups opposed to the BAF's surveillance activities and their desire to find out whether they had a BAF informant in their organisation. ${ }^{142}$ A covert intelligence war had begun which would continue as each side adopted the tactics of the other. The watchers could also become the

\footnotetext{
139 The claim was made by J. Edgar Hoover while testifying before a house committee in 1930-'Reds Reported Luring Negroes', Los Angeles Times, June 11, 1930, p. 5.

${ }^{140}$ Better America Federation, Weekly Letter, June 23, 1925, No. 314, Box 6, JRH/UCLA.

141 Ibid.

142 'Radicals Steal Secret Papers', Los Angeles Times, October 30, 1925, p. A1.
} 
watched but the BAF, unlike its opponents, had the support and protection of the Los Angeles Police Department, which was increasingly becoming active in its own surveillance activities.

The BAF aspired to represent all 'right-thinking' white Americans, but like many business associations whose members clash with their employees over wages and other conditions, they employed others to do the fighting. In Los Angeles the main enforcer of labour discipline was Captain William Hynes, chief of the LAPD Intelligence Bureau, whose career was supported by the BAF, the M \& M, and other patrons which similarly relied on the maintenance of the openshop for economic or political dominance. A veteran of WWI and member of the American Legion after it formed in 1919, Hynes had briefly worked as a labour spy for the San Joaquin Light \& Power Company in 1921, a major BAF contributor, and then as a freelance investigator in both San Diego and LA until March 1922. ${ }^{143}$ In April 1922 Hynes became a patrolman for the LAPD, and due to his previous experience was immediately assigned to an undercover role 'investigating the activities of Anarchists, Communists, Syndicalists, Socialists, and other radical groups and organizations' ${ }^{144}$

Hynes spent until the end of 1923 undercover, during which time he successfully infiltrated local chapters of both the Communist Party and the IWW. ${ }^{145}$ This assignment was a formative one-Hynes spent 8 months from mid-1922 posing as an IWW agitator on the docks of San Pedro, leveraging his undercover identity's existing membership of the Communist Party to become the editor of the strike bulletin and a member of the IWW leadership's inner circle. According to Scott McLellan, Hynes acted as an agent provocateur while undercover, urging several IWW members to escalate the strike by blowing up ships in the harbour. ${ }^{146}$ Hynes presumably believed that by encouraging such violence he would supply the police with the pretext to crack down even harder on the IWW, but these actions aroused suspicion amongst his peers, who had also been alerted by Hynes' occasional lapses into police

\footnotetext{
${ }^{143}$ California journalist Franklin Hichborn had investigated major financial contributors to the BAF in the early 1920s-Franklin Hichborn to Randolph Haynes, February 8, 1924, Box 6, JRH/UCLA.

${ }^{144}$ Hynes' LAPD personnel file was subpoenaed by the La Follette Committee, and is reprinted in-Committee on Education and Labor, Subcommittee Investigating Violations of Free Speech and the Rights of Labor, 'Personal History and Record of Wm. F. Hynes', Hearings before a Subcommittee of the Committee on Education and Labor, (Washington, D.C: G.P.O, 1940), pt. 64, pp. 23511-2. [Hereafter referred to as Hearings on Violations of Free Speech \& the Rights of Labor]

145 The CP was then known as the Workers' Party of America.

${ }^{146}$ Scott Allen McLellan, 'Policing the Red Scare: The Los Angeles Police Department's Red Squad and the Repression of Labor Activism in Los Angeles, 1900-1940', (Ph.D. dissertation: UC Irvine, 2010), pp. 120-121.
} 
vernacular. He was eventually expelled from the IWW union, but not before he had collected enough surveillance to provide key testimony at the trials of several of his former comrades. Shortly after the IWW presence in San Pedro was finally and brutally resolved Hynes was rewarded with an appointment to head the newly formed Radical section of the LAPD Intelligence Bureau - known colloquially as the 'Red Squad'. ${ }^{147}$

During this period Hynes was engaged in collecting and archiving surveillance information of a large number of local organisations that the Intelligence Bureau deemed as radical. Under the directions of Acting Sergeant Luke Lane, Hynes was closely involved in the preparation of weekly intelligence reports on radical activities in Los Angeles, which indicate the selection of targets that the Red Squad was investigating at different times. One report at the end of 1924 records the activities of strikers, labour unions, anarchists, communists, syndicalists, socialists, the ACLU, and pacifists - the standard groups reported on each week. That report particularly stressed the activities of the ACLU, recording the subscribers to the debut issue of its Open Forum publication, noting the transfer of its headquarters to another building, and providing summaries of its meetings through an informant placed to record the speeches and individuals present. ${ }^{148}$

Perhaps as a result of his clerical duties Hynes developed an affinity for the efficient archiving and retrieval of vast quantities of documents. His personnel file records this trait, giving him credit for a special assignment in which he designed and supervised the installation of a central filing system for the Police Commission. ${ }^{149}$ In this respect Hynes was like many other prominent red-hunters, who likewise recognised the value of centralised archives of surveillance information.

The Los Angeles Times supported Hynes' rising career and public profile with increasingly breezy articles detailing his exploits, which obscured the dirtier work he was engaged in. In March 1924, Hynes' was featured in a story of an LAPD raid on the Los Angeles headquarters of the IWW, where forty-two individuals there were arrested under the Busick injunction on

\footnotetext{
${ }^{147}$ Hearings on Violations of Free Speech \& the Rights of Labor, pt. 64, pp. 23511-2.

148 Luke Lane \& William Hynes, 'Confidential Weekly Summary of Intelligence', November 29 to December 5, 1924, Box 11, Records of the Special Committee on Un-American Activities, 1938-1944, National Archives and Records Administration, Washington, D.C. [hereafter referred to as Dies/NA]

${ }^{149}$ Hearings on Violations of Free Speech \& the Rights of Labor, pt. 64, pp. 23511-2.
} 
suspicion of Criminal Syndicalism. A front page photograph of Hynes from the Times story detailing the raid shows him arranged at a desk surrounded by a smiling group of colleagues as they examine the 'radical literature' seized in the raid. ${ }^{150}$ A light hearted January 1925 article detailed the nattily dressed Hynes' attempts to recover $\$ 145$ worth of 'fine raiment' from police evidence after another IWW raid during which his attire had been mistakenly collected as evidence. ${ }^{151}$ A further article in October 1925 celebrated Hynes' arrest of a man engaged in a solo picket outside of a Los Angeles theatre which refused to pay him a union wage scale. ${ }^{152}$ These public accounts of Hynes' work granted a nonchalant, almost genial air to a police unit that was already beginning to develop a reputation for brutality.

In 1927 Hynes' was promoted to acting Captain of Detectives, and assumed leadership of the Intelligence Bureau as a whole. His primary duty as head of the Bureau was to manage the 'investigations, surveillance, arrest and prosecution of illegal activities in connection with ultraradical organisations and individual'. Among Hynes' other specific tasks were to assist the United States Immigration Bureau with the deportation of alien radicals, collect and archive information on radical organisations of all types, oversee surveillance of all open and public meetings of radical groups, liaise with Department of Justice, Army and Navy intelligence officers, prepare intelligence reports for the LAPD Chief of Police, and to display the results of collected radical material on the communist threat for public consumption. A further task was to protect 'legitimate labor organisations' such as the AFL and Railroad brotherhoods against the 'IWW, Communists and other Red "borers from within"' who might seek to exploit the labour movement for its own ends. The same directive was applied to the protection of employer's associations, which faced 'sabotage, racketeering, illegal picketing', and 'molestation and assault of employees' who sought to work while their colleagues striked. ${ }^{153}$

The same year that Hynes assumed leadership of the Intelligence Bureau the U.S. Supreme Court ruled on the constitutionality of the California Criminal Syndicalism law, which had been the subject of repeated legal challenges by Anita Whitney since 1920. The case of this

\footnotetext{
150 'Radical Plot Suspects Questioned', Los Angeles Times, March 3, 1924, p. A1.

151 'He Loses Sleuthing Garb', Los Angeles Times, January 1925, p. A5.

152 'Novel Picket Plan Foiled', Los Angeles Times, October 10, 1925, p. A1.

153 'Scope, Functions and Operations of the Intelligence Bureau of the Los Angeles Police Department', June 1936, Box 46, Dies/NA.
} 
middle-class 'parlor pink' had become a national liberal cause in the intervening years, attracting widespread attention and accompanying disbelief that Whitney could be a representative of the red menace supposedly threatening California. In May 1927 the Court upheld the constitutionality of the CS law and its use in her original conviction, which somewhat rehabilitated the law that had suffered significant public and legal doubt since at least 1924. Whitney herself was pardoned almost immediately by California governor C. C. Young, but her long appeals process led to the constitutional vilification of the CS law, ironically aiding the revived use of the CS law in the 1930s.

A renewed proponent of the use of Criminal Syndicalism laws was William Hynes, because it allowed what the Busick injunction did not-convictions on the basis of ideology, in a public court that would condemn the actions of radicals. The fact that these convictions could be secured through the use of subversive documents collected by surveillance operatives was another benefit, since a key provision of the Criminal Syndicalism law allowed the prosecution of anybody who 'Prints, publishes, edits, issues or circulates or publicly displays any book, paper, pamphlet, document, poster or written or printed matter' that advocated criminal syndicalism. ${ }^{154}$ Though it had initially been crafted to aid in the repression of the IWW, it was flexible enough to be useful in the prosecution of Communist Party members as well, provided that the prosecution had sufficient documentation and testimony to establish that the CPUSA similarly advocated the violent overthrow of the US government. Hynes would have an opportunity to use his own expertise and surveillance material at the end of the decade, when a renewed surge of radical activity seemed to overtake Los Angeles, spilling out east into the agricultural areas of the Imperial Valley.

The first trial to convict under California's Criminal Syndicalism laws since the end of 1923 was precipitated by events that took place on January 1, 1930, when Mexican and Filipino lettuce pickers in the Imperial Valley decided to strike for better pay. With their sole demand a modest wage raise, the Mexican workers' union representatives were advised by their consul to keep the strike peaceful and legal by avoiding mass picketing or any other activities that might provoke violence. According to the prosecution's case in the trial that followed, the strikers were soon joined by communist organisers of the Trade Union Unity League [TUUL] from Los

\footnotetext{
${ }^{154}$ See the Appendix of this thesis for the full text of the California Criminal Syndicalism Law.
} 
Angeles, who immediately attempted to assume control of the strike. The Filipinos were receptive to their efforts, while the Mexicans were not, creating a racial rift among the striking workers, which was exacerbated when the Mexicans voted to return to work at the same time TUUL representatives were making plans for a long, drawn-out struggle. ${ }^{155}$ Strikes continued intermittently over the next month, as further TUUL members and other communists headed to the Valley from Los Angeles.

At the end of February a major riot erupted in Los Angeles over a communist-led mass meeting. The battle that ensued was described by the Times as a 'fierce riot', with the LAPD locked in combat with 'hordes of reds' in in the city's Plaza. Though LAPD officers assembled in response to the meeting had 'used every peaceful means to keep the throngs in order', the spark was reportedly struck by LAPD attempts to prevent the crowd from blocking traffic. The Times account of what happened next included hysterical 'red amazons' stabbing at police eyes with their deadly umbrellas, placards 'ranting against American government', and buckets of blood flowing in the streets-a revolutionary uproar that threatened the city until finally LAPD officers resorted to tear gas to control the crowd. In its most heroic portrait of Hynes yet the Times described Hynes actions in thick of the fight-engaged in hand-to-hand battle, choked with tear gas, and at the head of a retaliatory assault on a Communist Party meeting when the main uprising was over. ${ }^{156}$ The threat was clear-this is what the CPUSA envisioned for the future of California.

On April 14, 1930 simultaneous raids were conducted by law enforcement in the Imperial Valley towns of Brawley, El Centro and Calexico, where the TUUL had offices. During the raids large quantities of 'propaganda and organization literature' were seized by arresting officers, along with all of the TUUL leaders present. Subsequently, fourteen individuals were indicted by grand jury for the crime of Criminal Syndicalism. ${ }^{157}$ The three separate counts charged to each defendant asserted that they were all members of an organisation which advocated or abetted criminal syndicalism, had 'by spoken and written words' aided or abetted Criminal

\footnotetext{
155 'Summary of Evidence' in the People of the State of California v. Tsuji Horiuchi et al., c. May 1930, Box 47, Dies/NA.

156 'Hordes of Reds Battled in Fierce Riot at Plaza', Los Angeles Times, February 27, 1930, p. 1.

157 'Summary of Evidence' in the People of the State of California v. Tsuji Horiuchi et al., c. May 1930, Box 47, Dies/NA.
} 
Syndicalism, and were further guilty of the felony charge of a conspiracy to commit criminal syndicalism through the use of violence to affect industrial change. ${ }^{158}$

As the trial was being prepared, Imperial County district attorney Elmer Heald warned of reports from Los Angeles that a new group of radicals were headed for the Imperial Valley to aid in the agitation of revolt amongst farm workers, information that must have come to him from the LAPD Intelligence Bureau. ${ }^{159}$ One of Hynes' key contributions to this preparatory stage was to provide Heald with the evidentiary basis for arguments that no member of either the International Labor Defense [ILD] or the ACLU should be permitted to serve on the trial's jury. To do so Hynes paraphrased from documents collected on the organisations by his officers over the last six years, compiling a history of their foundation, membership and public actions. The results showed that the ILD 'is an official communist organization, $[\ldots]$ officered and controlled by the communist party', and therefore because of party discipline its members could not be trusted to serve impartially on any jury.

Although the ACLU was not specifically a communist organisation itself, Hynes' report claimed that it was nevertheless 'in complete sympathy with the radical ideas and programs of the red organizations' ${ }^{160}$ According to the report, this traced back to its early involvement with pacifist and anti-draft groups in the First World War, from which it emerged 'a radical defense organization operating under the guise and pretext of championing the rights of free speech, free press, and free assemblage'. ${ }^{161}$ According to Hynes, the Los Angeles branch of the ACLU was particularly radical, and had 'succeeded in enlisting the active aid of many of the so-called wealthy parlor Bolshevik or "pinks"' in churches, colleges, and universities. As was pointed out to the trial judge as a further justification for prohibiting ACLU members to serve on the jury, both counsels for the defence were ACLU members. ${ }^{162}$

\footnotetext{
158 'Indictment' in the People of the State of California v. Tsuji Horiuchi et al., April 30, 1930, Box 47, Dies/NA.

159 'Imperial Girds for Red Influx', Los Angeles Times, April 24, 1930, p. A11.

160 'Summary of Evidence' in the People of the State of California v. Tsuji Horiuchi et al., c. May 1930, Box 47, Dies/NA, pp. 25-31.

${ }^{161}$ Among the somewhat more serious charges asserted against the group were allegations that this early predecessor of the ACLU was guilty of 'encouraging naturally timid boys and discontents to register as conscientious objectors', and 'pointing out to mothers and friends the means employed by others to escape military service'.

162 'Summary of Evidence' in the People of the State of California v. Tsuji Horiuchi et al., c. May 1930, Box 47, Dies/NA, pp. 25-31.
} 
Hynes lent his further aid to the trial itself which began at the end of May 1930. This included his testimony, where he spoke about his experiences as an undercover agent in the CP and IWW during the San Pedro strikes, where he helped to bolster the argument that the CP was an organisation advocating the overthrow of the US government, a necessary precondition to validate the first charge the defendants were indicted with. Hynes also appeared as an evidentiary expert on radical and subversive propaganda. Drawing on this expertise, Hynes was called upon to identify and explain various pieces of evidence seized during the raids, which he asserted proved both the party membership of the defendants and the violent revolutionary ideology of the $\mathrm{CP} .{ }^{163}$ These included items such as membership cards, red flags, copies of the Daily Worker, CP manifestos, quotations from Marx and Lenin, and minutes from recent CP meetings in Los Angeles which Hynes had provided himself. ${ }^{164}$ Between his testimony and his evidentiary expertise, Hynes was instrumental in the prosecution's case in both the first and second charges.

On the felony charge of conspiracy to commit criminal syndicalism the trial heard from three undercover informants who had infiltrated the TUUL. Their testimony alleged that the defendants had by joining the CP and TUUL entered into a conspiracy to 'bring about a change of industrial ownership and control', and had planned to use violent means in pursuit of that aim, including forced picketing, and the destruction of the melon crop through sabotage of railroads and packing sheds. ${ }^{165}$ When the jury returned on June 13, 1930 they agreed, finding nine defendants guilty of all three counts of Criminal Syndicalism, the first such convictions since 1923. Having admitted their CP membership, strike agitation, and advocating sabotage, the defendants had not put up much of a fight. ${ }^{166}$

The trial had been a success for a number of reasons. For one thing it boosted Hynes' solidifying reputation as a reliable trial expert on radicalism, one who could secure documents and testimony with the ability to link labour agitators to revolutionary organisations. The successful conviction of the defendants in the Imperial Valley trial was undoubtedly due in

\footnotetext{
163 Ibid, p. 49.

164 Ibid, pp. 50-54.

165 Ibid, pp. 8-9; 'El Centro Convicts Nine Reds', Los Angeles Times, June 14, 1930, p. $1 .$.

166 'El Centro Convicts Nine Reds', Los Angeles Times, June 14, 1930, p. 1; Frederic Nelson, 'Red Hunting is Brisk from Coast to Coast', The Sun, July 22, 1930, p. 11.
} 
large part to his involvement. It was also useful because it demonstrated to Hynes and others that successful prosecutions under Criminal Syndicalism laws were once again possible in California. The fact that they had first been successfully employed against communist organisers in the state's agricultural fields was another significant achievement for Hynes and Imperial Valley authorities, and an augur of the challenges facing the state when the depression spread to California.

\section{Conclusion}

During the 1920s the BAF and the LAPD Red Squad became active collaborators in a conservative project to place radicals under surveillance, keep out unions, and generally maintain Los Angeles as an 'open shop' city in keeping with the Otis-Chandler vision which the M \& $M$ and the Chamber of Commerce had championed since earlier in the century. Haldeman and Hynes were key figures in this process of repression. Each entity they controlled collected intelligence, often gathered covertly, as a part of their normal operations.

The BAF was primarily active in the civic, educational, and business spheres of the city, where it exerted various kinds of pressure to prevent labour organisation within the city, but also any suggestion of radical thought or even progressive reform that might reduce the power of business to control the city's government or its police force. It pursued the same goals at the state level, becoming an important arm of the conservative wing of the Republican Party that dominated California. Unleashing a parade of accusations asserting radical influence throughout institutions including the public education system, labour unions, the state government, the YWCA, and others, the BAF repeatedly wielded the threat of communism as a political spectre in order manipulate the public and achieve its aims.

The LAPD demonstrated its own usefulness as a repressive tool of business first during the crackdown on the IWW, and then later during the port strikes at San Pedro, where Hynes became personally involved in the surveillance and repression of IWW strike leaders. As he rose to prominence and leadership out of that conflict, the 'Red Squad' of the LAPD Intelligence Bureau built an archive of surveillance on radical movements. To understand this information 
the LAPD borrowed the categories of suspicion broadcast by the BAF and other patriotic movements, which showed them how to track the personnel and ideology of the communist conspiracy they claimed was poised to strike at the heart of the labour movement, and indeed, the nation.

At the beginning of the 1930s Hynes helped to demonstrate the value of the meticulous documentation and archiving of the surveillance material that Hynes had been collecting over the previous six years as head of the Radical section of the LAPD Intelligence Bureau. This opportunity came when communist agitators were accused of fermenting revolution among striking agricultural workers in the Imperial Valley. Reviving the state's Criminal Syndicalism laws which had fallen into disuse after the destruction of the IWW, Hynes deployed his surveillance archive and the categories of suspicion underpinning it to argue that the CPUSA were the new harbingers of revolutionary radicalism in California.

Both the BAF and the LAPD shared in this task, further aided by the Los Angeles Times, which as Chandler's mouthpiece acted as a cheerleader, offering its own exhortations to the Los Angeles public to view radical heretics and unions as equivalent and equally undesirable. Perhaps it was these public exposures which attracted the attention of Hamilton Fish, Jr., chairman of the Special Committee to Investigate Communist Activities in the United States (1930, also known as the Fish committee), which would visit Los Angeles a few months later to hear testimony. The hearings that took place would fill national headlines of the first year of the 1930s with lurid accounts of the communist threat - the beginning of a mutually beneficial relationship between Californian surveillance groups and anti-communists in congress that would endure the remainder of the decade. 


\section{CHAPTER 2: SURVEILLANCE (1930-1935)}

Surely, you don't seriously contend that the communists have any rights under the Constitution they are attempting to destroy? - LAPD Captain William Hynes, 1931. ${ }^{167}$

Since the First World War the city of Los Angeles had been controlled by a combination of tyrannical transport magnates, corrupt mayors, brutal police chiefs, wealthy publishers, and other surrogates for city administration. These men had used that power in pursuit of personal wealth and the maintenance of favourable social and economic conditions controlled by a conservative Republican, Anglo-Saxon status quo in the city. The repression of unions, communists, pacifists, IWWs and other radicals had always been a part of that campaign, coupled with the promotion of the city as the 'white spot' of the United States-a public relations campaign which idealised the city as a racially and politically homogenous utopia, open for business and investment, and a place where ambitious men with the right politics could amass their fortunes.

By the late 1920s this collective enterprise had faced certain self-inflicted setbacks. The unravelling of the Los Angeles-based Julian Petroleum Corporation in 1928 created a scandal, implicating a large number of local business leaders in a scheme to protect their oil investments at the very large expense of thousands of small investors. ${ }^{168}$ Haldeman of the BAF was one of the figures indicted in the Ponzi scheme, along with Hollywood icons Louis B. Mayer and Cecil B. De Mille-all respected public figures damaged by the exposure of their financial collusion with corrupt businessmen. This exposure highlighted the hypocrisy of figures such as Haldeman, who had publically proclaimed their personal morality as a prototype for ' $100 \%$ Americanism' and as protectors of Los Angeles virtue against the 'Creeping Communism' represented by 'Parlor Pinks' and labour unions.

\footnotetext{
${ }^{167}$ William Hynes, 'Open Letter to the Editor of the Los Angeles Record', November 30, 1931, Box 46, Dies/NA.

${ }^{168}$ For an in-depth discussion of the Julian oil episode see Jules Tygiel, The Great Los Angeles swindle : oil, stocks, and scandal during the Roaring Twenties, (New York: Oxford University Press, 1994)
} 
Coming as it did on the heels of the stock market collapse, the Julian oil scandal was partly symptomatic of the wider economic malaise that confronted California, and particularly Los Angeles, as it entered the 1930s. The collapse of the stock market in 1929 and the depression which followed produced widespread unemployment, hunger, and disillusionment. In the evaluation of members of California's fledgling surveillance organisations this was a potentially incendiary combination which radicals would undoubtedly seek to exploit. Sharing their evaluation of the radical threat, US Representative Hamilton Fish launched an investigation into Communist activities which he blamed for an upsurge in unemployment protests in 1930. Law enforcement nationwide responded with crackdowns and arrests, which the ACLU noted had dramatically increased since 1929. Los Angeles was among the most repressive parts of the country, wrote the ACLU, 'where the Better America Federation does its patriotic duty'. ${ }^{169}$

When the Special Committee to Investigate Communist Activities in the United States visited Los Angeles it signalled a new level of cooperation between congressional fact-finding committees, local patriotic groups and law enforcement organisations. The revelations before that committee by members of California's surveillance organisations exposed to the public the information they had collected on radical movements over the course of the 1920s, along with the categories of suspicion they had developed to interpret that data. In the words of ACLU historian Richard Donner, the Fish committee encouraged the institutionalization on a local level of surveillance of radicals by publicizing and encouraging police activities in this area', accompanied by a campaign of public fear-mongering to elicit support for such activities. ${ }^{170}$

These encouragements attracted the attention of the recently retired 'father' of U.S. Military Intelligence, General Ralph Henry Van Deman, who feared a Communist insurgency might be underway. In response Van Deman began the collection and dissemination of political intelligence on Californian citizens whose politics he suspected, forming effective links with both official and private actors in other locations throughout the state and nation. In this fashion like-minded individuals in San Francisco and San Diego became useful allies in surveillance collection, sharing intelligence, ideologies, and personnel with their counterparts in Los Angeles. Van Deman's presence in San Diego precipitated a new level of cooperation between

\footnotetext{
169 The American Civil Liberties Union, The Fight for Civil Liberty, 1930-1931, (New York: ACLU, 1931), p. 5.

170 Donner, Protectors of Privilege, p. 44.
} 
these groups. As a participant in a burgeoning anti-radical network Van Deman archived vast quantities of surveillance information on various suspect groups and individuals in California and beyond. State, county, and city law enforcement created a demand for this documentary catalogue by pursuing new prosecutions under the Criminal Syndicalism Act which had been revived in 1930 by Captain Hynes of the LAPD Intelligence Bureau.

Meanwhile the labour movement, buoyed by the provisions of the National Industrial Recovery Act [NIRA] passed in 1933, was entering a period of growing strength in California and the United States. This was manifested in renewed efforts by communists to organize San Joaquin and Imperial Valley farm workers in the early 1930s, and in the reappearance of the International Longshoreman's Association [ILA] on the Pacific Coast, which Harry Bridges helped lead through a series of strikes designed to end employer domination of the San Francisco waterfront. ${ }^{171}$ The growth of the labour movement in turn escalated the use of surveillance as a tool to go after organisers and strikers, backed by employer groups formed in the wake of California's escalating industrial strife. Through vigilantes, private detectives, strike-breakers, and sympathetic media and public officials, employers in the agricultural areas of California crushed any and all opposition to their control of the industry, leading contemporary critics to voice their fears that a revolution was indeed taking place, but one led by fascists, not communists.

As asserted by a labour historian, by the mid-1930s 'industrial espionage had become not only an accepted part of labor relations but the most important form of labor discipline services provided by "anti-union specialists"' working with patriotic and employer groups. ${ }^{172}$ In California, this development was led by participants in a state-wide surveillance network that incorporated patriotic societies, law enforcement, military agencies, employers' associations, undercover informants, and countless others.

\footnotetext{
${ }^{171}$ For a discussion of communist strategy in California during the first years of the 1930s, see Robert W. Cherny, 'Prelude to the Popular Front: The Communist Party in California, 1931-1935', American Communist History, Vol. 1, No. 1, 2002, pp. 5-42.

172 Robert Smith, From Blackjacks to Briefcases, p. xvi.
} 


\section{The Fish Committee investigates Los Angeles}

At just after 10am on the morning of Mar 10, 1930, Harry Marston Haldeman succumbed to a heart attack while on the witness stand in Los Angeles' City Hall Court. The man who in 1920 had been labelled Los Angeles' 'most useful citizen' by the city's realtors for his efforts promoting the city was reportedly dead before he hit the floor. Memorialised as a 'capitalist and a civic leader' by media as far afield as the Chicago Tribune, Haldeman received a front page tribute in the Los Angeles Times which praised him for his 'patriotic and philanthropic' contributions, while also crediting him as a 'leading figure in the Republican party in this state'. ${ }^{173}$ Harry Chandler, the publisher of the Times, was one of Haldeman's pallbearers. Haldeman's deputy Jo Joplin died the following day. As secretary and manager of the organisation for over a decade, Joplin had been chosen as the BAF delegate to the National Americanism conference held in Washington D.C. in May 1924. ${ }^{174}$ After the loss of these two key figures the BAF completed the move away from its previous raison d'etre as the chief enforcer of open-shop discipline in Los Angeles, and towards a more discrete role as surveillance gatherer and disseminator. Another significant factor was the arrival in Los Angeles of Hamilton Fish and the investigative committee he chaired.

On October 8, 1930 Fish and his colleagues began hearing testimony from a succession of local anti-subversives eager to help expose the red conspiracy in their schools, neighbourhoods, and cities. Through the conduct of the hearings that followed, the publicity they generated, and the recommendations for repressive legislation that followed, the Fish committee demonstrated to anti-communist surveillance operatives the value of courting congressional allies with the power to enact specific legislation to curb their opponents. Significantly, the first speaker at the Los Angeles hearings of the Fish Committee was Lieutenant Colonel Leroy F. Smith, editor of the BAF's publications and director of its propaganda 'speakers' bureau.

\footnotetext{
173 'Harry M. Haldeman, Capitalist, Collapses in Court,' Chicago Tribune, 11 March 1930; 'H.M. Haldeman Answers Call', Los Angeles Times, March 11, 1930, p. A1; 'Harry. M. Haldeman,' Los Angeles Times, March 12 1930, p.A4; 'Haldeman Funderal Today', Los Angeles Times, p. A1.

174 'Civic Guardian taken by death', Los Angeles Times, March 12, 1930, p. A1.
} 
To set the stage Smith began his testimony with a lengthy discussion of the organisational structure of the CPUSA and its alleged front-groups, supplying a series of documents to aid his contentions. The most interesting of these drew on an earlier representation of the communist threat-the much-circulated 'Spider Web Chart' which had been published in 1924 and alleged a complex conspiracy between pacifists, women's groups and socialism. ${ }^{175}$ Smith's modern update was titled 'The Ties that Bind'-a large fold-out chart submitted as an exhibit which claimed to illustrate 'the interlockages which exist among the various types of RADICAL, PACIFIST, DEFEATIST, SOCIALIST and INTERNATIONALIST Societies active in the United States' ${ }^{176}$ The main target of the chart was the ACLU, distinguished by its place in a column outlined in bold ink. In his explanation to the committee Smith asserted that the chart demonstrated 'the astonishing unity of brains and genius' behind $\mathrm{CP}$ front groups, and that by tracking the overlapping memberships in various leftist or pacifist organisations the 'ties that bind' the conspiracy together could be observed. ${ }^{177}$ Organisations listed included the Women's International league for Peace and Freedom, the Fellowship for Reconciliation, the Socialist Party, and the League of Women Voters. Illustrations indicated the connections between organisations and individuals, and the central indictment against all the entities represented was a mutual desire for recognition of the Soviet Union. Though he undoubtedly drew on the 'Spider Web Chart' for inspiration, and capitalised on the success of its rhetorical form, Smith's update was clearly the product of the BAF's own ideological concerns. As such it aimed to convince the public through the Fish Committee of the validity of the BAF's categories of suspicion-namely that organisations even remotely opposed to militant patriotism, total private ownership of public utilities, and the open shop were part of an international communist conspiracy headquartered in Moscow.

Captain William Hynes of the LAPD Intelligence Bureau also testified before the committee. Like Smith before him Captain William Hynes received a considerable degree of

\footnotetext{
${ }^{175}$ Lucia Maxwell, 'Spider Web Chart: The Socialist-Pacifist Movement in American is an Absolutely Fundamental and Integral Part of International Socialism', The Dearborn Independent, 22 March, 1924, Accessed 24/11/2013 from http://womhist.alexanderstreet.com/wilpf/doc3.htm.

${ }^{176} \mathrm{~A}$ copy of this document is contained in the surveillance records compiled by Ralph Van Deman- Leroy Smith, 'The ties that bind', Box 1, R-40F, RHVD/NA. It is also reprinted in Special Committee on Communist Activities in the United States, Investigation of communist propaganda. Hearings before a Committee to Investigate Communist Activities in the United States, (Washington, D.C.: GPO, 1930), Pt. 5, Vol. 3 [hereafter referred to as Investigation of communist propaganda].

177 Investigation of communist propaganda, Pt. 5, Vol. 3, p. 8.
} 
respect and careful attention from the members of the Fish Committee, who even deferred to his preferences for committee procedure. Hynes began by entering into the record a long list of organisations which he characterised as 'Communist influenced' due to their membership including one or more CP members. In tune with Smith's testimony, Hynes focused here on labour, anti-military, or civil liberties organisations, again with the ACLU as a major target. Slowly and casually, Hynes read the membership figures of these organisations into the official record, which the committee dutifully recorded without comment-it seemed enough for Hynes to name an organisation for it to be recorded as subversive. As a result, the LAPD exhibits entered the committee record just as presented, regardless of their origins or veracity, effectively becoming 'evidence' that might be used for legislative remedy or public relations purposes in the future. ${ }^{178}$

Hynes spent the majority of this time testifying on the activities of District 13 of the CPUSA, the organisational district corresponding to California, Nevada, and Arizona. According to Hynes, District 13 was among the most important to the central $\mathrm{CP}$ executive committee due to several important characteristics of the Los Angeles environment, which necessitated intense surveillance to protect the city against communist activities. The first reason cited was because Los Angeles encompassed several large military installations, particularly the naval base in San Diego, where 'the party intends to begin active agitation among the armed forces'. Communist agitators similarly threatened harbours at San Pedro and San Francisco, where naval personnel and waterfront workers would be targeted with anti-war and anti-imperialist propaganda due to their strategic military importance. The second key reason for $\mathrm{CP}$ activism in Los Angeles was the potential for its manufacturing base to be retooled for military production. The third reason according to Hynes was its immense agricultural hinterland which produced much of the national food supply. ${ }^{179}$

This last point was expanded in Hynes' further testimony, where he claimed that the Communist 'party is already planning a military organizational fight in the Imperial Valley'. ${ }^{180}$ This assertion was seconded by Elmer Heald, the District attorney from Imperial County who

\footnotetext{
178 Investigation of communist propaganda, Pt. 5, Vol. 4, pp. 8-53.

179 Ibid, p. 10.

180 Ibid, p. 11.
} 
had solicited Hynes' help to secure the Criminal Syndicalism convictions of communist organisers in the Imperial Valley a few months earlier. According to Heald, and despite the success of that trial, the CPUSA continued to send organisers into the Valley. Appealing for federal aid, Heald argued that his county lacked the resources to combat what he claimed was a well-armed and mobilised force of communist-led agricultural workers. ${ }^{181}$ Oligarchical landowners had long enjoyed the privilege of a marginal and easily exploited labour force in the Imperial Valley, and events subsequent to the trial show that the CP had indeed prioritised the region as one for agitation and organisation. Hynes' testimony thus correctly identified the appeal of Los Angeles' key industries and institutions to the CPUSA, which had targeted the base of the city's contribution to the national economy. Clearly, Hynes' surveillance activities had been effective.

In a further prophetic moment Hynes predicted that the fledgling Hollywood film business would fall under the sway of CP activists eager to exploit the industry's propaganda potential. Hynes described his efforts to prevent these communist 'Agitation and Propaganda activities', which included working to prevent the screening of pro-Soviet films in Los Angeles, done 'through the efforts of patriotic societies' - presumably referring to the BAF and the American Legion, of which Hynes was a member. Although there was no law against showing pro-Soviet films, these groups pressured theatre-owners to deny the use of their venues to communist organisations. ${ }^{182}$ Because Sergei Eisenstein, the director of Battleship Potemkin and Strike was then in Los Angeles to make a film for the Paramount-Laskey Corporation, the committee also questioned Hynes about his suspicions of the Soviet director. Not long afterwards, Paramount voided their contract with Eisenstein, citing artistic differences. ${ }^{183}$ These episodes, though comparatively minor, clearly prefigure the later attention that would be devoted to the activities of the Hollywood film industry.

Despite the committee's obvious sympathies, dissent continued to be voiced. As director of the Southern California branch of the ACLU, the Reverend Clinton J. Taft defended his organisation at the close of the second day's hearings, and revealed that he had been subjecting

\footnotetext{
${ }^{181}$ Investigation of communist propaganda, Pt. 5, Vol. 3, pp. 257-266.

182 Investigation of communist propaganda, Pt. 5, Vol. 4, pp. 22-3.

183 Donald T. Critchlow, When Hollywood Was Right: How Movie Stars, Studio Moguls and Big Business Remade American Politics (New York: Cambridge University Press, 2013), pp. 18-21.
} 
the BAF's activities to close scrutiny. Taft began by pointing out the concerted nature of the attack- 'What you have heard today has been from the Better America Federation's standpoint and, since you have been in Los Angeles, all the witnesses have been employees of the Better America Federation'. ${ }^{184}$ To combat Smith's 'Ties that bind', Taft read from an ACLU pamphlet that listed the membership of the group's national committee, pointing to its political pluralism while arguing that 'a committee [...] of that type can not be fairly designed [sic] as a Communist Party committee'. ${ }^{185}$ Despite the committee's refusal to hear testimony about violations of communists' civil rights, Taft charged William Hynes and the LAPD Intelligence Bureau with systemic brutality and illegal conduct. ${ }^{186}$

For this Chairman Fish rebuked Taft, revealing one of the vital qualities of the congressional committee-an ability to generate 'hard facts' at whim, and at the control of the committee or its allies. These facts could then be called on by subsequent committees and anticommunists when needed. As Smith had done, Fish cited the 1920 report of the New York State Joint Legislative Committee to Investigate Seditious Activities, popularly known as the Lusk Committee. This committee, chaired by State Senator Clayton Lusk, had then described the newly established ACLU as a 'supporter of all subversive movements', implying that Taft's criticism of the LAPD was part of a campaign to 'encourage attacks upon our institutions in every form'. ${ }^{187}$ In doing so, Fish was appropriating the legitimacy offered by an earlier investigative committee to designate certain organisations as subversive co-conspirators with the $\mathrm{CP}$, just as his own committee was creating its own catalogue of subversives.

John Beardsley, another member of the Southern California ACLU, placed his own defence of the organisation on the public record in his testimony before the Committee. While Taft came to the ACLU from a congregational background, Beardsley was a lawyer and the arguments he made before the committee drew on this training. This led Beardsley to ask the committee for the right to cross-examine Smith to challenge his assertions about the ACLU. Denied this right, Beardsley replied that 'it does not seem to me to be fair to permit witnesses to slander an organization and not permit the representatives of that organization to bring out the

\footnotetext{
${ }^{184}$ Investigation of communist propaganda, Pt. 5, Vol. 3, p. 299.

185 Investigation of communist propaganda, Pt. 5, Vol. 3, p. 304.

186 Ibid, pp. 308-310.

187 Ibid.
} 
truth from that witness' ${ }^{\prime}{ }^{188}$ Instead Beardsley attempted to enter into the record testimony about the conduct of Hynes and the LAPD Red Squad, which he claimed habitually broke the law in pursuit of repression rather than conviction. In his view, such tactics were violations of constitutional protections against unlawful search and seizure. ${ }^{189}$ Beardsley then ceded the floor to Upton Sinclair who, like his colleagues in the ACLU, testified that repressive violence by the LAPD and other groups was the chief factor radicalising workers in Los Angeles. When asked by a disbelieving committee member whether it was not true that communism had been imported into California through immigration, Sinclair replied that such workers 'were not communists when they came here, but have been made communists by the police brutality, and the brutality of the big corporations in connection with strikes' ${ }^{190}$ These three ACLU witnesses were the sole dissenting voices heard in the Los Angeles hearings of the Fish Committeevoices smothered by the hostility of the committee members.

Before adjourning the Fish committee again called upon Smith to testify, at which point he submitted the BAF's recommendations for federal legislation to combat communism in the United States. Foremost among the recommendations was the imposition of mandatory loyalty oaths for every immigrant entering the country, enabling the punishment of those who failed to honour it. The BAF wanted loyalty oaths required for 'every public employee, Federal, State, county, and municipal, and every person engaged in teaching in any capacity, and every person employed in any public utility, Government work, including arsenals, munitions plants, and essential industries'. ${ }^{191}$ Such oaths would enable punitive consequences for those targeted by the BAF and other groups engaged in surveillance-supplying grounds for their dismissal from public service and the public educational system.

Other BAF recommendations sought to tighten immigration laws applying to individuals both before and after entry into the United States. The first component of these recommendations was a proposal to expand the specific types of political activities that would prohibit the entrance of undesirable immigrants in the first place. Alongside this was recommended a loosening of the legal restrictions on deportation that had frustrated attempts

\footnotetext{
188 Ibid, pp. 317-8.

189 Investigation of communist propaganda, Pt. 5, Vol. 3, pp. 320-1.

190 Ibid, p. 328.

191 Ibid, p. 332.
} 
to expel political undesirables currently or previously in the US. Thus even if the first barrier could be overcome and naturalization secured, the BAF-proposed legislation would enable the government to rescind citizenship and deport any recent immigrant who had 'belonged to any proscribed organization', or aided a foreign government, or participated in 'any revolutionary movement aimed at the destruction or weakening of the institutions of this Republic'. In response to the legal inability to deport radicals born in the United States, the BAF proposed an expansion of federal sedition based upon the 1917 Espionage Act and its 1918 amendments colloquially known as the Sedition Act. The BAF asserted that 'hostility is a matter of fact, not a matter of date', thereby seeking to apply the wartime-specific claim of 'exceptional circumstances' at all times. In the view of the BAF, the 'criminal' who conspired against the government 'when it is unwary, unsuspecting, and unprepared' was even more dangerous than one committing a seditious act during wartime when the nation was on full alert. The BAF recommendations thus rejected any punitive distinction between various types of radicals, such as the one between alien radicals and American-born citizens. Indeed, Smith argued, 'the man who has enjoyed the institutions of America from birth is meaner in his sedition than he who came but recently'. ${ }^{192}$ Since deportation could not occur in the case of disloyal but native born citizens, the BAF proposed lengthy terms of imprisonment instead.

These recommendations on immigration were only part of the wider platform for a 'Better America' that Smith proposed, which also featured the group's recommendations for education policy. Vigilance against radical youth had long been a key feature of the BAF's activism, due to its fear of radicalised students whose 'infectious malady would breed sedition' amongst their earnestly patriotic yet seemingly fickle peers. ${ }^{193}$ The Los Angeles Times echoed this language of disease in its coverage of the hearings, justifying the BAF's focus on education with its own warnings about 'children who may become infected in their formative years with subversive ideas which will affect their whole lifetimes'. ${ }^{194}$ The fact that tax dollars paid for the education of these youthful subversives only added to the outrage. The BAF thus proposed an ideologically purified school system, which not only excluded communists and other radical

\footnotetext{
192 Investigation of communist propaganda, Pt. 5, Vol. 3, pp. 330-33.

193 Ibid, p. 333.

194 'School Plots of Reds Told', Los Angeles Times, October 9, 1930, p. A1; 'Congressmen End Red Quiz', Los Angeles Times, October 10, 1930, p. A1.
} 
youth, but also 'pupils who have developed thievery, immorality, and/or disease'. These exiled and unwanted-political, moral and physiological degenerates-would be quarantined away from their peers, where they would receive 'specialized corrective training' to cure such maladies. ${ }^{195}$ Having failed in its attempts to have similar measures adopted in the Los Angeles school system, the BAF sought to make these regulations a federal responsibility. The realisation of these ambitions would establish a minimum standard of patriotism necessary for participation in the public school system of the United States; a curriculum to inculcate Americanism as defined by the BAF. ${ }^{196}$

The Los Angeles hearings of the Fish Committee generated two published volumes of reports. Almost half of the first 450-page volume detailed Smith's testimony and the accompanying exhibits submitted by the BAF. The remainder of the first volume contained the testimony of those who Taft had dubbed 'employees' of the BAF, including national guardsmen, law enforcement representatives, a school principal, and a sympathetic judge. Testimony by Hynes was the only part of the Los Angeles hearings which received more coverage in the Fish committee reports than did the BAF. Declaring to the public that Hynes had supplied 'the most lucid and comprehensive report on radical activities that they had received since they left Washington', the committee members devoted the entire second volume to his testimony and exhibits, amounting to over 1500 pages in total. ${ }^{197}$ No other organisation or individual during the committee's nationwide series of hearings received this singular distinction, a testament to what the committee saw as the expertise of Captain Hynes and the LAPD Intelligence Bureau. Moreover, and in spite of the extent of the subterfuge and undercover activities carried out by the LAPD, the veracity or even providence of the material Hynes submitted went largely unquestioned.

To account for this, it is imperative to recognise that the public exposure generated by the Los Angeles hearings advanced the interests of all the sympathetic parties involved. The Fish Committee gained political prestige and publicity for its members, credence for its warnings of communist conspiracies, and legislative support. The BAF acquired a national platform for its

\footnotetext{
195 Investigation of communist propaganda, Pt. 5, Vol. 3, p. 332.

196 Ibid, p. 333.

197 'Congressmen end red quiz', Los Angeles Times, October 10, 1930, p. A1; Investigation of communist propaganda, Part 5, Volume 4.
} 
surveillance and patriotic work as well as its proposed legislative solutions, which, it later claimed with satisfaction, coincided with the Fish Committee's own recommendations. ${ }^{198}$ Hynes similarly gained a larger public profile, as well as a public endorsement of his methods as the appropriate response to the communist menace.

The Los Angeles Times also benefited through the receipt of an abundant supply of ideological ammunition with which to defend its longstanding editorial conservatism, seizing on the disclosures before the Fish Committee to rally public sentiment with the publication of the juiciest revelations. 'Agitators Seek to Infect City's School Children', bellowed one headline, while another proclaimed 'Communists Boast of Plans to Overthrow Nation'. ${ }^{199}$ Together these groups collaborated in an apparatus of repression, surveillance and exposure that successfully crafted a comprehensive anti-communist spectacle for both a local and national audience. Keen observers of this process in the ACLU and elsewhere were now more alert than ever to the practices and ambitions of their surveillers, and might well have begun crafting their own version of the 'Ties that bind' in the aftermath.

\section{San Diego's Archivist-General}

The public revelations provided by the Fish Committee alerted many Americans to the new radical 'threat' posed by a growing CPUSA membership. One individual who paid particular attention was retired Military Intelligence General Ralph Henry Van Deman, who in his former career had created an intelligence and surveillance network in the colonial Philippines which proved to be instrumental in disrupting an anti-U.S. insurgency. According to historian Roy Talbert, it was the Fish Committee's revelations about CP activities that compelled Van Deman in 1932 to begin the application of this counter-insurgency expertise to

\footnotetext{
${ }^{198}$ Better America Federation, 'The Findings of the Red Probe', Weekly Letter, February 6, 1931, p.2.

199 'Evidence given of red plots... Agitators Seek to Infect City's School Children', Los Angeles Times, October 9, 1930, p. 1; 'Investigators Hear Reds Rave... Communists Boast of Plans to Overthrow Nation', Los Angeles Times, October 7, 1930, p. 6.
} 
Southern California. ${ }^{200}$ Over the next three decades Van Deman compiled an immense archive on the political proclivities of Californian citizens suspected of disloyal thoughts or actions, from which he offered sensitive information to various collaborators and political allies.

Van Deman was aided in this task by a long list of sympathetic organisations. These included patriotic groups such as the BAF, the American Legion, the Civic Council of Defense $[C C D]$ in Long Beach, the Associated Farmers of California $[A F C]$, as well as official agencies like the State Bureau of Identification [BOI], several County Sheriffs' and District Attorneys' offices, and the police forces of both San Diego [SDPD] and Los Angeles. Van Deman similarly drew on contacts from his previous career to gain access to military sources, most regularly the Office of Naval Intelligence [ONI] as well as through his former colleagues at the Military Intelligence Corps of the Army [G-2]. These groups and others all contributed to Van Deman's archival clearinghouse for surveillance information, an operation that Van Deman believed would disrupt the communist revolution he feared would soon take start in California.

The archive started out fairly modestly, and during the first two years Van Deman relied heavily on three groups in particular-the SDPD, the BAF, and the army and naval intelligence forces of the U.S. military. As shown in Chart 2.1 below, Van Deman received at least twentythree texts (or collections of texts) from the BAF, twenty texts either from or through the SDPD in 1932 and 1933, and sixteen from either the army or navy intelligence agencies. ${ }^{201}$

\footnotetext{
200 Ray Talbert, Negative Intelligence: The Army and the American Left, 1917-1941 (Jackson, MS: University of Mississippi Press, 1991), pp. 234-235.

${ }^{201}$ While individual citizens supplied at least twenty-three texts to Van Deman, they were rarely from the same person more than once. It is not possible with absolute certainty to trace the origins of all the documents in VD's archive, and in the case of nineteen documents collected in 1932-33 the providence is uncertain.
} 


\section{Chart 2.1: Origin of Documents in Van Deman Archive,}

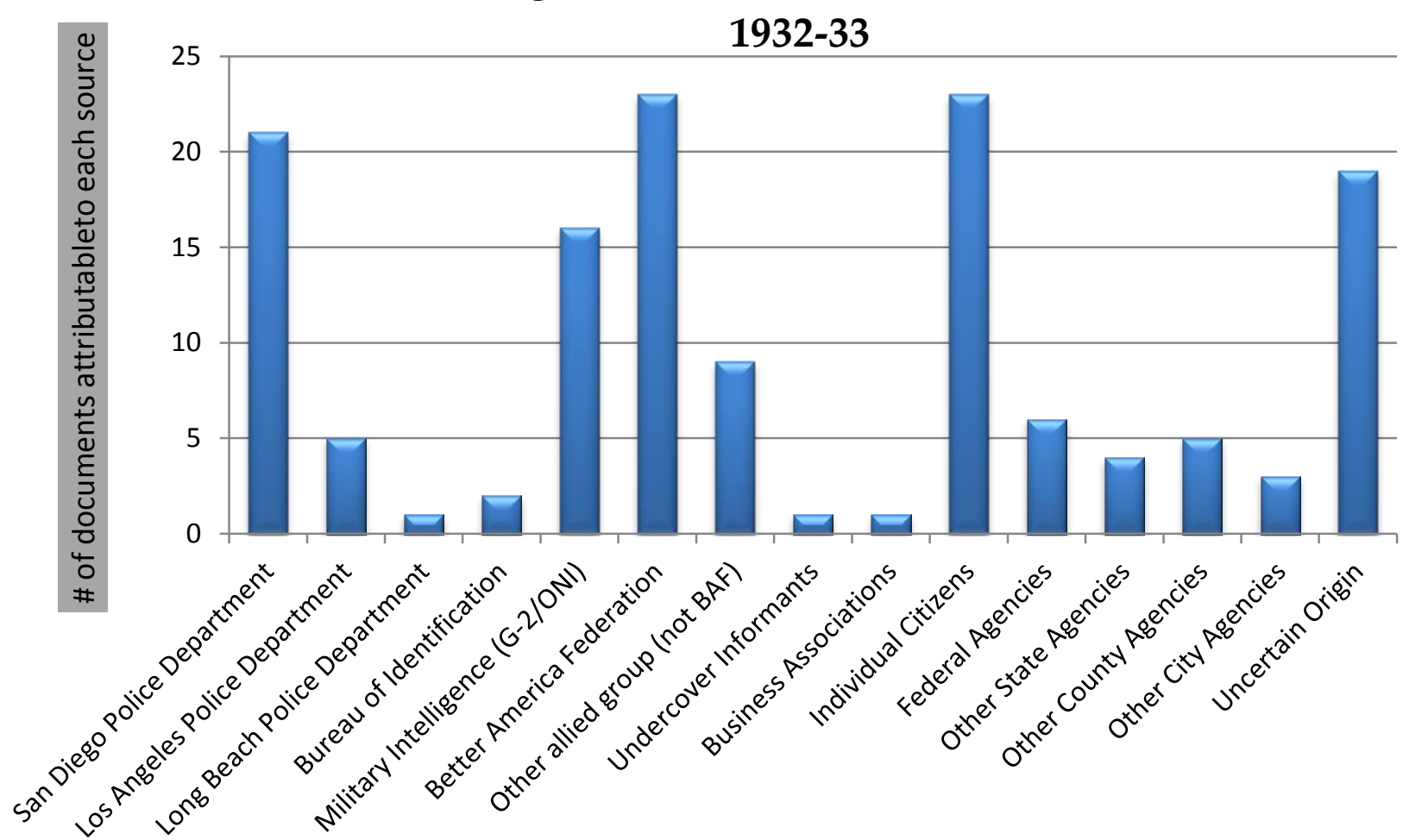

Institutional affiliation of contributors to VD Archive

By the time of Haldeman's death in March 1930 the BAF had already begun backing off from its former leader's emphasis as an enforcer of ideological discipline among the city's business class. Under Margaret Kerr's direction, the BAF instead focused increasingly on the surveillance and archival activities that had granted it national publicity during the Fish committee hearings. As Van Deman would begin to do in 1932, this had long involved the collection of large amounts of covert information on radical activities, and the circulation of this information with the BAF membership through the Weekly Letters as well as to other likeminded groups and individuals who shared their concerns. In 1930 alone, the BAF claimed to have distributed over half a million pages of this information through the efforts of their 'research division'. ${ }^{202}$ A glowing profile of Kerr printed in the Times few years later compared her life's work to that of 'a soldier training for leadership in the defense of his country', though an ideological one-devoted to the acquisition and most complete filing of every tittle of information concerning the personnel, publications, propaganda and activities of every

202 'Better America Federation, foe of radicals, starts thirteenth year of patriotic work', Los Angeles Times, January 11, 1931, p. A1. 
movement designed to undermine the Constitution and government of these United States' ${ }^{203}$ Kerr had laboured at this task since joining the BAF in 1920. Given the organisation's experience and public profile, it is unsurprising that it was one of the first groups that Van Deman reached out to, and his most active collaborator.

Contact began in July 1932 with a letter from Kerr to W. F. Haber, the vice-president of a San Diego bank, in which she warned of a communist 'whispering campaign' which might soon be targeted against his bank. Designed to effect mass withdrawals of public funds from targeted banks, these campaigns allegedly sought to capitalise on shaken public faith in the financial industry after the Wall Street crash of 1929, and were widely reported throughout the nation. ${ }^{204}$ The BAF themselves had covered these 'poison-gas sabotage schemes' extensively over the previous year, even publishing a Special Bulletin dedicated to a detailed examination of the various tactics that were allegedly being carried out. ${ }^{205}$ Kerr recommended that Haber 'maintain a watchful surveillance over all sessions of the unemployed councils of [Communist Origin] in your city', and directed Haber to forward the information on to 'reliable authorities' in San Diego. ${ }^{206}$ Following Kerr's advice, Haber passed the letter and attached information on the suspected perpetrator to Van Deman.

Over the next several months Van Deman continued to grow his archive, collecting intelligence material from an expanding variety of official sources and concerned citizens. From October 1932 Van Deman began to receive the personal correspondence of San Diego communists, including letters to young members of the communist Young Pioneers group from pen-pals in Russia. These were likely sent to Van Deman from the U.S. Post Office in San Diego, who for several years continued to forward letters from the same address, which Van Deman had identified as the home of a communist family. ${ }^{207}$ Van Deman must have shared his

\footnotetext{
203 'Woman Patriot on Guard', Los Angeles Times, March 5, 1934, p. A6.

204 "Red Bank Plot' link denied by Powers', New York Times, July 29, 1932, p. 36; 'Government acting on Bank Run 'Plot", New York Times, July 28, 1932, p. 1; 'The Communist Program', Los Angeles Times, July 29, 1932, p. A4; 'Plots of Reds to Wreck Nation's Banks Exposed', Los Angeles Times, July 28, 1932, p. A1.

205 Better America Federation, Special Bulletin, January 5, 1931, R-67, Box 1, RHVD/NA.

${ }^{206}$ Margaret Kerr to W. F. Haber, July 13, 1932, R-11a, Box 1, RHVD/NA.

${ }^{207}$ Harry Nurmiaho to Charles Clarkin, October 17, 1932, R-19a, Box 1, RHVD/NA; Stella Salmi to Katherine Clark, December 27, 1932, R-19b, Box 1, RHVD/NA; Anna Kozik to Katherine Clark, R-19c, Box 1, RHVD/NA; Alpha Scott to Comrade McNamara, May 8, 1934, R-19e, Box 1, RHVD/NA; The document R-969 is a letter from the assistant postmaster of the US Post Office in San Diego to Van Deman, enclosing a tracing of the address on 'another letter
} 
enthusiasm for this material with the BAF, because in December 1932 Van Deman received a request for copies of the Young Pioneer letters from Abraham Hoffman, a BAF member in Los Angeles who wanted to reprint the letters in the BAF Bulletin. With his letter Hoffman enclosed an index to the Fish Committee report, and thanked Van Deman for an item he had shared earlier-a list of delegates to a recent anti-Criminal Syndicalism conference in San Diego which Hoffman assured would be passed on to both the BAF and the LAPD. ${ }^{208}$ By the end of 1932, such gifts had certainly demonstrated Van Deman's ability to procure valuable material to the anti-communist elite of Los Angeles, which they could then utilise in their own ways-the BAF through publication, the LAPD through prosecution or other means of repression.

Though the BAF were Van Deman's number one collaborators after December 1932, he still received a substantial number of documents from the SDPD in both 1932-33, including some of the very first information on suspected communists in the archive. ${ }^{209}$ The majority of these texts are official police reports from SDPD detectives assigned to attend meetings of suspected radicals. The first report of this kind was sent to Van Deman at the end of January 1932, after he had requested a plainclothes officer be assigned to a local meeting of the unemployed to record 'any off color actions or speeches'. ${ }^{210}$ Van Deman may have been disappointed with the descriptive quality of the report he received afterwards: 'Officer Griffith and myself was detailed to go to the meeting. There were 65 people there. Three speakers their [sic] names were not given when they were introduced'. Still, what detail the report did contain must have confirmed Van Deman's suspicions, as the officer noted one speaker's intention 'to organize strong enough to overthrow this form of government what he called imperial form of

which has been secured in accordance with your desires' - Assistant Postmaster to Van Deman, September 24, 1935, R-969, Box 6, RHVD/NA.

208 Charles Hoffman to Van Deman, December 17, 1932, R-23, Box 1, RHVD/NA.

209 The archive was organised chronologically by date that each piece of information was collected. 'R-1' is the first piece of information that Van Deman entered into his collection, in this case a brief report on a German communist with possible links to Elsa and Albert Einstein. When a piece of information was collected later that was immediately relevant to an earlier text it was assigned the same ' $R$ ' number, along with a letter designation to indicate this. Thus, for example, the letter to the editor of The Broom registering a protest about the imprisonment of labour martyr Tom Mooney is entered into the archive as 'R-15b'. 'R-15c' is another letter of a different date concerning the Bonus Army-impoverished WWI veterans that were agitating for outstanding pay from the US government. Both letters relate to radical causes, seemingly unconnected, but in this case the link was the author. Both letters are signed by what appear to be pseudonyms, but the handwriting suggests that the author was the same-thus Van Deman grouped the letters together in his archive for ease of reference. It is difficult to know the context of these documents, but it is likely that Van Deman suspected the author of being a communist, and was interested in having his or her handwriting on record.

${ }^{210}$ Memo from unknown officer to Asst. Chief Patrick, January 22, 1932, R-2a, Box 1, RHVD/NA. 
government and talked of what Lennen [sic] had done in Russia and wants to make the whole world like Russia'. ${ }^{211}$ This somewhat crude report began a nevertheless fruitful collaboration between the SDPD and Van Deman; one of the more significant partnerships of his postretirement surveillance operation.

Van Deman also had another, more eloquent source at the meeting. The three page report that the observer codenamed 'SD-2' submitted to Van Deman gave considerably more detailed information on many aspects of the meeting - the appearance of speakers and attendees, the content of speeches, reactions to the speeches, the procedures of the meeting, and many other details. This observer was also sophisticated enough to recognize the significance of the singing of The Internationale at the opening and adjournment of the meeting, to highlight the use of terms such as 'proletariat' and 'class consciousness', and astute enough to observe that the final speaker was 'well received by the audience, altho I do not believe all he said was understood'. Though the identity of the author is unknown, some of the statements made in the report suggest that the author was not a police officer. In the introductory description of the people present, for example, the author notes the attendance of 'a few well dressed and of average intelligence (probably 'observers' from police and civic bodies)' outsiders among the mostly destitute audience. ${ }^{212}$ Though hardly conclusive, this suggests that the author was from neither group. This level of detail must have necessitated extensive note-taking while at the meeting, not something easily done incognito. When combined with the undercover designation SD-2 that appears in place of a signature at the end of the report, it seems reasonable to conclude that the author was a surveillance professional, or perhaps a journalist-somebody Van Deman had known in his former career in military intelligence. ${ }^{213}$ As an officer Van Deman had gained a reputation for 'intrigues', a trait that he continued to exercise in his post-retirement surveillance operations.

\footnotetext{
211 'Officers Report concerning Communist Meeting at $9499^{\text {th }}$ street', January 23, 1932, R-2a, Box 1, RHVD/NA.

212 'Report on meeting for purpose of organizing Communist Party', c. January 1932, R-2b, Box 1, RHVD/NA, pp. 1-3

${ }^{213}$ Though likely a coincidence, the internal designation for army intelligence is $G-2$, the ' $G$ ' standing for the rank of the officer (in this case $G=$ general), the ' 2 ' denoting the intelligence office attached to that unit. If Van Deman saw himself as San Diego's de facto head of military intelligence (and certainly others did), the pseudonym SD-2 would be an appropriate designation for himself. It is certainly conceivable that Van Deman did his own surveillance work on occasion.
} 
Though the SDPD was Van Deman's key law enforcement contact, the LAPD did provide intelligence to Van Deman in 1933 on occasion. In April 1933, he received a ranked list of the categories of suspicion the LAPD was then using, perhaps for Van Deman's instructive purposes. Ranking the various radical threats in order of 'relative importance and potential danger', public enemy number 1 was the CPUSA, 'together with its numerous subsidiary and affiliated organisations', which included many of the labour organisations in which communists had been identified. According to the LAPD, there were around $850 \mathrm{CP}$ members in Los Angeles. Second on the list was the ACLU, with around 300 members that the LAPD referred to as 'Parlor Pinks', regurgitating the 1920s term to denote middle-class leftist sympathizers. These preachers, lawyers and professors were deemed more threatening than those in the third category, the 'anarchist groups and individuals', which retained a minor presence in several Los Angeles ethnic European communities. Next was the IWW themselves, the 'revolutionary syndicalists' whom the LAPD had succeeded in demolishing during the 1920s-now deemed only marginally more deadly than the final group, the generic 'Socialists'. The LAPD list demonstrates the changing perception of the radical threat in California, and also what had remained constant. Though the IWW had been supplanted by the CPUSA, the ACLU remained a significant threat.

By 1932 San Diego was already home to one of the largest naval fleets on the West Coast. That year Consolidated Aircraft Co., later a major supplier of WWII aircraft to the U.S. army, began moving manufacturing operations to the city from Buffalo, New York. They were drawn to Southern California in particular by the promise of lower wages and the unorganised workforce proclaimed by the boosters of the 'white spot' and the 'open shop', joining Douglas, Lockheed and other manufacturers which would provide the industrial base for the 1930s expansion of the US Pacific Fleet. ${ }^{214}$ For both naval and army intelligence maintaining vigilance over the burgeoning Pacific Fleet was a key priority, and one that would continue throughout the decade as the $\mathrm{CP}$ began actively recruiting sympathisers from among the military. During his service Van Deman had risen to the rank of Brigadier-General, and thus shared the concern

\footnotetext{
${ }^{214}$ One of the key causes for Consolidated Aircraft's total shift of manufacturing to San Diego in 1935 was a strike in the Buffalo plant that lasted fifty days. For a comprehensive discussion of the history of West Coast aviation labour see-Jacob Vander Muelen, 'West Coast Labor and the Military Aircraft Industry', Pacific Northwest Quarterly, Vol. 88, No. 2, Spring 1997, pp. 82-92.
} 
of high-level officers that pacifist and communist politics were undermining the nation's military preparedness. It was through this prism of suspicion that Van Deman and his former colleagues in the military exchanged surveillance material.

Geographically, Van Deman and the ONI collaborated on communist surveillance in the area defined by the eleventh naval district, corresponding to the state of California south of Santa Barbara and eastwards through southern Nevada to Arizona. Van Deman's key contact at the ONI was Commander A. A. Hopkins, who had previously been a special agent for the Bureau of Investigation in Los Angeles during the early 1920s, and was also a Deputy Sheriff of Los Angeles County. ${ }^{215}$ In December 1932 Van Deman received his first substantial piece of intelligence from Hopkins, a list of Japanese Communists in California which had been found in the possession of the 'notorious alien Japanese Communist' K. Hama by U.S. Immigration officials. ${ }^{216}$ A month later Van Deman received two more documents from the ONI, including an intelligence summary from an undercover agent in the Los Angeles CP. The summary warned that a party member named James Dixon would soon be heading to San Diego, having been assigned to organise a strike among celery pickers in the agricultural areas east of the city. ${ }^{217}$ The third document was a surveillance report on the movements of a communist organiser who was travelling down the Pacific Coast, setting up local chapters of unemployed veterans to agitate for government relief. ${ }^{218}$ Taken together, these three documents are typical of the scope of the intelligence that Van Deman received from sources in the ONI, which often focused on alien (especially Japanese) radicals, communist attempts to ferment strikes in key industries, and communist infiltration of political or labour organisations. Armed with this sort of information Van Deman would act as a coordinator between different levels of the anti-

\footnotetext{
${ }^{215}$ Hopkins' early 1920s assignments included the investigation of African-American uplift groups and suspected communist screen icon Charlie Chaplin. It is possible or perhaps even highly likely that Hopkins and Van Deman had worked together during WWI. Several of Hopkins' reports on African-American organisations in Los Angeles are reprinted in Marcus Garvey \& Robert Hill (eds.), The Marcus Garvey and Universal Negro Improvement Association Papers, (Berkeley: University of California Press, 1983), pp. 63-4, 84-5, 99-100, 163, 176, 224, 252, 279, 321, 354; Hopkins' reports on Charlie Chaplin can be found in the publically available FBI file on Chaplin available online-A.A. Hopkins, 'Charlie Chaplin, et al, Los Angeles, Cal. COMMUNIST ACTIVITIES', August 14, 1922, Charlie Chaplin FBI File, accessed 12/01/14 from http://vault.fbi.gov/charlie-chaplin

${ }^{216}$ A. A. Hopkins to Commandant Eleventh Naval District, 'Japanese Communists', December 1, 1932, R-28, Box 1, RHVD/NA.

${ }^{217}$ B. P. Hastings to Commandant, Eleventh Naval District, 'James Dixon, Organizer, Unemployed Council', January 19, 1933, R-30, Box 1, RHVD/NA.

218 B. P. Hastings to Commandant, Eleventh Naval District, 'Workers Ex-Service Men's League', January 23, 1933, R37, Box 1, RHVD/NA.
} 
communist apparatus in California-for example, by relaying information on $\mathrm{CP}$ members travelling throughout California to local law enforcement so they could be watched or apprehended.

Van Deman regularly received surveillance and other information from the Military Intelligence Corps of the US Army [G-2]. This information would typically come from San Francisco, where the Ninth Corps Area of the third army was headquartered at the Presidio. In April or May 1933 Van Deman received a large package of information from G-2 which described the arrest in San Luis Obispo of two local communists on suspicion of possessing a stolen car. Though that turned out not to have been the case, the two men did possess large amounts of what a G-2 officer described as 'communistic literature', which they attempted to destroy by tearing and swallowing. G-2 were alerted, and concluded from examining the literature that the two men 'gave every indication of being duly accredited agents of an organization having for one of its principal objectives, the disintegration of the National Guard, Regular Army, Navy and Marine Corps units and other branches of our national defense'. According to the report this was the first time in many years that 'accredited agents' had been captured in California while in possession of documents linking them personally to the Communist Party, and Van Deman shared in the haul of insights into the politically deviant mind they offered. ${ }^{219}$ Unfortunately for the authorities nothing in their possession was evidence of a crime, and without a specific complaint the arresting officers could do no better than a charge of vagrancy. Despite the lack of a conviction, Van Deman had gained a substantial amount of information on the inner workings of the CP in California, which he would later use to connect the two men to several communists in San Diego. ${ }^{220}$

Together with the innate prestige of his rank, his regular contact with military intelligence provided Van Deman with a credibility that must have appealed to the many individual

\footnotetext{
${ }^{219}$ Captain H. A. Hansley \& Lieutenant M. G. Mauer to Colonel John U. Calkins, April 26, 1933, R-91a, Box 1, RHVD/NA. Documents R-91b to R-91g are reprints of some of the literature the men were arrested with. ${ }^{220} \mathrm{R}-108 \mathrm{~b}$ is a letter authored by Van Deman to 'my dear Everson', and provides a rare glimpse into Van Deman's editorial attitude towards the information he collected and how he used it. In the letter Van Deman connects recent events that had taken place in the communist world, and on which he had collected information. Weaving it all together Van Deman concludes that the $\mathrm{CP}$ 'is actively engaged in trying to organize Communist units among the enlisted men on the ships of the Navy stationed here', and that a San Diego musician named William Jasmagy was the man behind it all. Amongst the documents collected by the two men arrested at San Luis Obispo appeared Jasmagy's name as the \#1 contact for the CP in San Diego. This single document is a valuable demonstration of exactly how the archive worked-Ralph Van Deman to Everson, August 5, 1933, R-108b, Box 1, RHVD/NA.
} 
citizens who communicated with him. This credibility allowed Van Deman to act as a kind of ideological gatekeeper on behalf of citizens concerned about local radical influences, many of whom believed the information would help them perform civic tasks in their communities. In return they would forward information to Van Deman about whatever radical activities they caught wind of. ${ }^{221}$ Van Deman provided this service regularly for Vesta Muehleisen, a member of the San Diego board of education. In February 1933 Muehleisen sought his help after a request from the Friends of the Soviet Union (FSU) to use a school auditorium for an educational conference. Muehleisen, privately supplied with Van Deman's assurances, replied to the FSU delegation 'are not the F.S.U in Russia Communists, and are not the headquarters in Russia, and if the F.S.U here was not allied with the Communist party in Russia[?]'.222 Armed with this information Muehleisen was able to create enough doubt amongst the board to ensure the FSU's application (and subsequent appeal) were unsuccessful.

By late 1934 Muehleisen attempted to transform her personal anti-communism into board policy, submitting a resolution to the board of education that would set limits on the types of organisations that would be allowed to use school facilities. Maintaining the right 'to judge and exclude from its program and its schools the advancement of those doctrines which are subversive to the principles of the Constitution of the United States', the resolution stated that after careful research it was clear that communists advocated the overthrow of the US government, denied any allegiance to the US flag, taught resistance to the law, sponsored strikes, riots, and murder, and possessed a desire to abolish private property and religion. As such, the resolution proposed that the board was absolutely opposed to 'the use of its buildings to further the doctrines of Communism'. Despite protest from members of the public present the board had by this point grown weary of having their meetings occupied by radicals seeking to gain an audience, and Muehleisen's resolution was unanimously approved by the board.223

In December 1934 the ACLU, itself a regular target of surveillance, sought to test the board of education's policy by applying to use school facilities for a meeting of its own. The ACLU sent several representatives to argue their case, including Paul Richie, a local socialist

\footnotetext{
${ }^{221}$ Vesta Muehleisen to Van Deman, December 28, 1934, R-728, Box 5, RHVD/NA.

222 'Notes on discussion regarding use of school auditorium by the F.S.U.', February 6, 1933, R-42, Box 1, RHVD/NA.

${ }^{223}$ Minutes of San Diego City Board of Education meeting, October 15, 1934, Series 2, Vesta Muehleisen Papers, San Diego History Center Document Collection, San Diego. [Hereafter referred to as VM Papers].
} 
and later Democratic Party assemblyman who had represented the FSU in their failed 1933 attempt to access school property.224 Richie had earlier attracted Van Deman's attention with the publication of an anti-military, anti-business political allegory entitled Five Men in a Boat. ${ }^{225}$ At the hearing the board was almost uniformly hostile, claiming that the 'information they had gathered' indicated that the ACLU was inextricably linked with communism, and thus 'beyond the pale'. ${ }^{226}$ Following the policy established by Muehleisen, the ACLU's application was denied by the board. The ACLU charged this was a breach of first amendment rights to free speech and a sympathetic judge agreed-issuing a writ compelling the board to produce information proving that the ACLU was a communistic group, and granting a full hearing in January. If they did reveal to the court that Van Deman was their source it was not reported, and by March 1935 local patriotic groups were celebrating victory after the judge ruled that the San Diego board of education's right to restrict access to their facilities superseded the ACLU's claim to free speech. 227

At the same December 1934 meeting the board also heard from the Public Works Union, formerly known as the SERA Workers' Union. The Public Works Union had used San Diego schools for meetings in the past, and wanted to know why their most recent request had been turned down. Only the previous month the board had indeed allowed the union use of school property-but only in order to allow surveillance operatives to observe their activities and collect information on their members. A letter from Crawford to Muehleisen records the way this set-up was conceived: 'I was advised by Mr. Walter Macy, Chief of the Bureau of Identification at the Police Department, that he in turn had been advised by General Van Deman that this organization was organized and controlled by the Communist Party, that this local unit was just one of many being organized through the State of California'. ${ }^{228}$ Macy

\footnotetext{
224 Paul Richie \& Jack Hardy to the San Diego Board of Education, February 20, 1933, R-48, Box 1, RHVD/NA.

225 Paul Richie, Five Men in a Boat, (San Diego: n.p., 1933), R-142, Box 1, RHVD/NA. The characters in Five Men in a Boat are named 'Business', 'Military', 'Labor', 'Professional', and 'Scientific'. While on a perilous voyage at sea, each applies their particular solution to the problems that arise. Before long Business and Military perish as a result of their foibles, leaving the other three to sail off into a bright future. Richie shows up elsewhere in the VD archive, including in 1933 as an applicant

${ }^{226}$ Minutes of San Diego City Board of Education meeting, December 17, 1934, Series 2, VM Papers.

227 'Civil Union scores in School Row', Los Angeles Times, December 23, 1934, p. 30; 'San Diego Civic Groups Rally to Combat Spread of Radical Doctrines', Los Angeles Times, February 9, 1935, p. 7; 'Civil Liberties Union Loses San Diego Court Battle Over School Use', Los Angeles Times, March 14, 1935, p. 14; 'Schools not open forums', Los Angeles Times, March 16, 1935, p. A4.

${ }^{228}$ George Crawford to Vesta Muehleisen, November 26, 1934, Series 2, VM Papers.
} 
advised Crawford to allow the Public Workers' Union meeting to go ahead, so that he could assign two officers to surveill it. The board complied with Macy's suggestion in order to aid the surveillance, and after the meeting received a copy of the SDPD's report on the meeting. The report confirmed Van Deman's suspicions, with Officers Whitney and Jansen of the SDPD ‘Red Squad' recognising over ten local communists holding important positions within the organisation. ${ }^{229}$ Crawford closed his letter to Muehleisen with a plea for discretion, concerned that this was 'a valuable source of information which might be curtailed if it becomes public knowledge that he is rendering us this assistance' ${ }^{230}$ Eager to conceal his involvement, Van Deman had been careful to channel the information through the intermediary of the SDPD.

Though Van Deman continued to maintain his vigil over San Diego after 1933, his attention was increasingly drawn to other parts of the state, where widespread industrial unrest in 1933 and 1934 had caught the attention of many of California's surveillance operatives. After a series of strikes in agricultural areas across California, culminating in the cotton strike in San Joaquin Valley in October 1933, Van Deman's surveillance archive became increasingly focused on those communists who were active in organising farm workers. During that strike violence against strikers, including several murders, had drawn federal authorities to intervene.

\section{The Network Expands}

Since the $1^{\text {th }}$ century agricultural production in California had been controlled by a white landowning elite who generally hired Mexican or Filipino immigrant labour to work their fields. Though the patterns of ownership remained largely unaltered from the 1920s, major demographic shifts during the 1930s brought new ethnic and economic pressures to bear on the already marginal population that actually worked the land. Over the course of the 1930s somewhere around three hundred thousand migrant agricultural workers arrived in California's farming regions, driven by depression, dust and drought from their homes in primarily Midwestern and Southern states like Kansas, Oklahoma, Arkansas, and Texas. This

\footnotetext{
${ }^{229}$ Report on meeting of Public Works Union, November 19, 1934, Series 2, VM Papers.

${ }^{230}$ George Crawford to Vesta Muehleisen, November 26, 1934, Series 2, VM Papers.
} 
abundance of marginalized, often migrant or dispossessed labour was a boon for employers, and in a time of almost uniform deprivation led to some of the lowest agricultural wages in the nation, as low as $\$ 2.00$ a day for a family of ten according to an investigation by the Los Angeles Illustrated Daily News. ${ }^{231}$ The fact that they were predominantly white Americans gave employers a further wedge with which to pursue racially divisive employment practices; so while Mexicans remained the majority ethnic group, and the best organized, white workers were often granted preferential pay rates and other entitlements to create a distinction between them and those on the absolute bottom tier of California's agricultural hierarchy. By doing so employers were able to use race interest to trump class interest, preventing poor workers from forming a united front. Workers were being strained to breaking point, and one of the first groups to recognise this was the communist-led Cannery and Agricultural Workers' International Union [CAWIU].

Over the course of 1933, the CAWIU's attempts to organize farm workers had finally found some success, with limited gains won after the successful passage of the National Industrial Recovery Act [NIRA] in June 1933. NIRA protected workers' rights to organize, to bargain collectively through representative organisations, and encouraged the regulation of workplace standards. Through the leadership of CAWIU organisers like Pat Chambers and Caroline Decker organising efforts culminated in the San Joaquin Valley strike of October 1933, during which over 18,000 workers walked off the fields. Though the opportunity offered by NIRA had emboldened labour organisers, they also provoked an inevitable backlash from the state's powerful agricultural interests. Though ranchers, growers and their allies had always responded forcefully they had previously done so with little coordination. With the passage of NIRA and the CAWIU's efforts that year many agriculturalists recognised that a viable movement was emerging to challenge the exploitative foundations of Californian agricultural labour. Their response was to form a state-wide coalition of agricultural, economic, and industrial interests to combat the labour movement, but which would act through the vehicle of localised paramilitary organisations who could aggressively pursue the leftist agitators it blamed for the crisis.

${ }^{231}$ The Illustrated Daily News is cited in-Carey McWilliams, 'The Farmers Get Tough', The American Mercury, October 1934, pp. 241-245. 
Seemingly separate attempts to form such an organisation began across California over the autumn and winter months of 1933-1934. The first group began in August 1933 with a meeting in Kern County, north of Los Angeles, of a small group of ranchers who were determined to 'relieve the cotton farmer of the ravages of politicians and paid organizers' ${ }^{232}$ Calling themselves the Associated Farmers, the group began dispatching delegates throughout the state to begin an organising drive. In September later local chapters had formed throughout the San Joaquin Valley, including in the town of Pixley, Tulare County. ${ }^{233}$ At the height of the strikes the following month two workers were shot in Pixley while CAWIU organiser Pat Chambers was addressing a crowd of workers. Local law enforcement, present at the scene, waited until the perpetrators had unloaded their shotguns into the crowd and fled before reluctantly intervening. ${ }^{234}$ Abraham Lincoln Wirin, chief counsel of the Southern California ACLU, described the attacks as 'deliberate cold-blooded murder', and the attempt to assign responsibility to Chambers for the violence as a 'frame-up'. ${ }^{235}$ While vigilantism was certainly one of the Associated Farmers' anti-labour tactics, the wider mobilisation of growers was more sophisticated and calculating than these local outbreaks of violence suggested.

Though they may have desired the appearance of a grassroots organising effort, the Associated Farmers quickly coalesced around a deliberate strategy organised by the bankers and other corporate interests that controlled much of the state's agriculture. In a November 1933 meeting of the California state chamber of commerce T. N. Wilson, director of the chamber's agricultural department, first presided over proposals to form a state-wide organisation. This proposed new entity would seek to incorporate and direct the activities of chapters of growers, shippers and other industrial interests at the local or county level, while engaging in public relations, fund-raising, research and lobbying at the state and national levels. Through the state Chamber of Commerce the group had access to some of the most powerful economic interests in California, who were urged to provide the funds necessary to build a united front among

\footnotetext{
232 'Cotton Raisers Organize', Los Angeles Times, August 25, 1933, p. A11.

233 'Farmers Form Benefit Group', Los Angeles Times, September 20, 1933, p. A8.

${ }^{234}$ For an account of the killings in the towns of Pixley and nearby Alvin see-Daniel Cletus, Bitter Harvest: A history of California Farmworkers, 1870-1941, (Ithaca: Cornell University Press, 1981), pp. 195-202.

${ }^{235}$ Wirin was quoted in The Militant, described as the official organ of the Trotskyite Communist League of America. A report containing these quotes was sent to Van Deman by the Civic Council of Defense, a Long Beach anti-communist organisation-'Report on Abraham Lincoln Wirin', c. November 1935, R-1130a, Box 8, RHVD/NA.
} 
employers. One valuable contributor was Harry Chandler, publisher of the Los Angeles Times, who assisted substantially with the fund-raising drive..$^{236}$

Though there had been violent strikes in Californian agriculture before, many Californians recognised that something had changed after October 1933, both in the numbers of strikers and the brutal anti-picketing measures employed by growers. As a result, state authorities were forced to intervene, taking the unprecedented step of providing food to striking workers. Confronted with tax-payer support for their opponents, the growing farmer's organisation held crisis meetings under the auspices of the Chambers of Commerce of both San Francisco and Los Angeles, where speakers were admonished for not having listened to the strident warnings put out by the Better America Federation. ${ }^{237}$ At the same time a variety of liberal and advocacy groups began sending large numbers of representatives to assist workers in the Imperial Valley, where lettuce pickers had begun a new campaign for better conditions. Organisations then active in the valley included the ACLU, the Women's International League for Peace and Freedom [WILPF], and the International Labor Defense [ILD], all groups which had been alleged by the surveillance network to be communist affiliated.

They arrived to find the whole county militarised and on edge, with armed groups ready and waiting for hostilities to commence. A perverse Times article gleefully revealed that 'it's a secret, but the vigilantes are really Legionnaires, and do they have fun'. Following LAPD Captain Hynes' advice to 'clean 'em out first and then arbitrate', growers in the Imperial Valley began targeting labour advocates directly in the following months. ${ }^{238}$ The first major incident involved Abraham Wirin of the ACLU, who travelled to the Imperial Valley town of Brawley for a mass meeting at the end of January to protest the treatment of striking lettuce workers. ${ }^{239}$ Concerned by the possibility of interference from Brawley's openly pro-grower law enforcement, Southern California ACLU head Clinton Taft took out a restraining order against the Imperial County Sheriff and Brawley chief of police. Still fearing for his safety Wirin wired the California Governor and U.S. Marshall in San Diego to demand protection, writing that

\footnotetext{
${ }^{236}$ Hearings on Violations of Free Speech \& the Rights of Labor, Part 55, pp. 20075-99.

237 'Fight launched on Reds', Los Angeles Times, January 11, 1934, p. A1.

${ }^{238}$ Chapin Hall, 'Red Strike Aim Fails', Los Angeles Times, January 15, 1934, p. A1.

${ }^{239}$ Both Wirin and his dinner companion Helen Marston of the WILPF were regular targets of Van Deman's surveillance. See, for example-'MONROE SWEETLAND. Activities from November 26, 1934 to December 8, 1934, inclusive', c. December 1934, R-799, Box 5, RHVD/NA.
} 
authorities in the Valley had 'suspended [the] U.S. Constitution and turned it into a scrap of paper', and were acting under Hynes' orders. ${ }^{240}$ Mindful of the restraining order, the local sheriff mobilised an American Legion 'riot squad' to take care of the situation on his behalf. ${ }^{241}$ Several hours later Wirin was accosted by this group of two dozen local men, who beat him, robbed him, and dumped him in the desert outside town. ${ }^{242}$

Further attacks indicated the continuing collusion between authorities and the vigilante forces. In February 1934, Hynes wrote to Imperial County District Attorney Elmer Heald, warning him that surveillance information indicated that Pat Chambers had recently arrived in the county from the San Joaquin Valley. ${ }^{243}$ The response from a County Superior Court judge indicated that a conference was being held with local law enforcement, where 'taking care of Mr. Pat Chambers in the proper way' would be arranged. ${ }^{244}$ Chambers was arrested soon afterwards, and detained indefinitely for violating a Brawley city anti-picketing ordinance. On March 24 Attorney Grover Johnson of the ILD was dispatched to El Centro with writs of habeas corpus for Chambers and another striker, compelling their immediate release. Immediately afterwards Johnson was assaulted by a group of men waiting for him outside the courthouse, who he concluded could only have been summoned by Heald. ${ }^{245}$ According to Johnson's account of the attack, this mob included a city councillor, and was further bolstered during the assault by a pre-arranged signal to summon vigilantes from the American Legion-several blasts on the 'city siren and fire whistles'. ${ }^{246} \mathrm{~A}$ succession of such assaults on workers over the previous few months had aroused many commentators to fury over the lawless atmosphere in California agriculture, which finally induced federal authorities to conduct an investigation.

\footnotetext{
${ }^{240}$ Hearings on Violations of Free Speech \& the Rights of Labor, Part 64, pp. 23644-5.

241 Ibid, p. 23646.

242 'Lawyer in S.D. Beaten by Kidnapers he Charges', San Diego Sun, January 24, 1934, R-236, Box 2, RHVD/NA; 'Man Seized in Strike', Los Angeles Times, January 24, 1934, p. A1. In the Times account Wirin was not subjected to any violence, just forcibly removed from the Valley.

${ }^{243}$ Hearings on Violations of Free Speech \& the Rights of Labor, Part 64, p. 23640.

244 Ibid, p. 23641.

${ }^{245}$ Heald also exchanged information with Van Deman regularly throughout 1934-1935, and was alerted by one of Van Deman's agents to the renewed presence of communist organisers in the Imperial Valley in mid-1934-Letter from 'Mr.B' to Van Deman, February 15, 1935, R-782e, Box 6, RHVD/NA.

${ }^{246}$ Hearings on Violations of Free Speech \& the Rights of Labor, Part 55, pp. 20140-4; Johnson asserted that councilman Osborne started the assault was Hugh Osborne, then chairman of the American Legion's Subversive Activities Committee.
} 
One of the critics enraged by the events in San Joaquin and the Imperial Valley was Carey McWilliams, who in the first of his many indictments of the state's agricultural labour practices alleged that the violence directed against the labour movement was being directed by a new organisation acting under the advice of Hynes. ${ }^{247}$ That organisation was the Associated Farmers of California [AFC], which had incorporated officially as a non-profit organisation in June 1934. Signalling their wider ambitions, the group also urged the adoption of a slate of bills then being proposed by Democratic Party congressman Martin Dies, Jr., of Texas, which would outlaw the Communist Party throughout the nation and facilitate the deportation of alien radicals. ${ }^{248}$ More immediately, one of the first announced goals of the group was to use the Criminal Syndicalism Law to jail the CAWIU leaders they alleged were the sole reason for the labour unrest. ${ }^{249}$ With Hynes' assistance that pursuit would bear results, but first California's employers would have to deal with another challenge from a newly invigorated labour movement on the Pacific Coast.

One of the major financial contributors to the AFC was the Industrial Association of San Francisco [IASF], who at the end of May was an organisation engaged on the front lines of its own pitched battle against strikers. ${ }^{250}$ Somewhat resembling Los Angeles' M \& M, the IASF was formed in 1921 by the San Francisco Chamber of Commerce as a militant open-shop advocate to advance the interests of the city's employers. San Francisco's dynamic tradition of unionism, particularly on the waterfront, had thus far caused the city's employers greater difficulties than their counterparts in Los Angeles. During the 1920s the IASF helped to change this, aiding waterfront employers with the introduction of employer-run 'shape-up' hiring halls, company unions and a de facto blacklist for recalcitrant workers, all of which worked to divide the port's workers and prevent them from organising effectively.

The maritime strikes of May 1934 were directly a result of these anti-union measures. By then waterfront workers in San Francisco had endured over a decade of employer control of the industry, increasing competition for limited jobs, and dwindling wages when work could be

\footnotetext{
${ }^{247}$ Carey McWilliams, 'The Farmers Get Tough', The American Mercury, October 1934, pp. 241-245.

248 'Red Ousterove Urged', Los Angeles Times, April 26, 1934, p. A20.

249 The letterhead on AFC publications identified June as the date of incorporation. The Associated Farmers continued to oppose attempts to repeal the CS law for a number of years, sending out a variety of related information on occasion to Van Deman. See, for example-Associated Farmers of California to anonymous [with attachments on CS law], April 9, 1935, R-833, Box 6, RHVD/NA;

${ }^{250}$ Hearings on Violations of Free Speech \& the Rights of Labor, pp. 20075-99
} 
found. As the depression wore on it compounded the already terrible conditions to such an extent that large numbers were forced to rely on government relief because of the scarcity of work in the early 1930s. Despite these grim prospects longshoremen were still forced to continue paying dues to the 'blue book' company union, to offer 'incentives' to the hiring hall bosses in order to secure work, and all the while to accept conservative representation which had no intention of confronting employers over the bleak situation..$^{251}$

After the enactment of NIRA in June 1933 waterfront workers began leaving company unions in droves. For many the logical destination was the International Longshoreman's Association [ILA] which, before the local chapter was broken in 1919, had been the traditional vehicle of representation for San Francisco longshoremen. Employers responded by locking out all workers who had not paid their dues or without the blue book designating company union membership, ultimately only increasing the flight to the ILA. By March 1934 enough longshoreman were solidly organised into a legitimate union to begin agitating for change, and demands went out for a 30-hour working week, a wage increase, control of the hiring system, and employer recognition of the ILA. Offered arbitration by employers on their other demands if they accepted an open shop, the ILA rank and file rejected the conciliatory position taken by their conservative AFL leadership, and voted to strike on May 9, 1934.

The ILA strike quickly spread to other ports after sympathetic unions walked off the job all along the Pacific Coast. Accusations of communist control of the strike soon followed in the Times, with the president of a major pacific shipping line claiming that information received through reliable channels' demonstrated beyond any doubt that radicals wanted to use the strike 'to break down the form of government under which we are working'. The president of the San Francisco chamber of commerce denied that it was an industrial dispute entirely, claiming instead that 'it is a conflict which is rapidly spreading between American principals and un-American radicalism', led by communists who were 'responsible for the violence, bloodshed which is typical of their tribe'. According to Chapin Hall of the Times, the San

\footnotetext{
${ }^{251}$ On these developments as well as the wider context leading up to the strikes, see Bruce Nelson, Workers on the Waterfront, Seamen, Longshoremen, and Unionism in the 1930s, (Urbana: University of Illinois Press, 1988), pp.105-6.
} 
Francisco chamber was just one of many 'disinterested organizations' that shared this conviction. ${ }^{252}$

Not since the San Pedro strikes of 1923-24 had workers been in a position to threaten a stranglehold over the shipping industry of the entire Pacific coast. Having learnt their lesson then, the administrators of the port at San Pedro established extensive fortifications over the intervening years, and were resolute in their determination to prevent San Pedro from being tied up. On May 15 two strikers were shot and killed by private guards hired by employers after attacking a fortified compound housing the strike-breakers. The LAPD deputy chief of police was subsequently assigned to keep the peace on the docks, but instead ordered Captain Hynes of the Red Squad to ensure Los Angeles' port remained open, the only one still unloading ships on the Californian coast. He did so with his usual efficient brutality, resulting in several charges of excessive force filed by injured strikers, included allegations that Red Squad officers had inflicted 'horrible pain and probably permanent injury to [strikers'] sex organs' ${ }^{253}$ Over the next few weeks the maritime strikes continued to escalate, with violent strike breaking efforts leading to sympathy strikes in other industries, until finally workers in the city of San Francisco called a general strike, only the second in the nation's history.

The story of how the Pacific Coast maritime strikes escalated into the 1934 general strike is well-known, as is the role of the Industrial Association of San Francisco in the confrontation and violence that characterised it. ${ }^{254}$ Briefly, after repeated attempts by the Industrial Association to bypass the pickets and open the docks, a confrontation developed between a group of strikers and the police. When this escalated several SFPD officers made the decision to use their firearms and a shotgun blast fired by one officer into the crowd killed two men. The city's populace reacted with outrage to the killings, and to the unrelenting violence that continued against the strikers and their allies in the aftermath. With widespread public support, a call for a general strike was put out by the San Francisco Labor Council on July 14, and for almost a week

\footnotetext{
252 'Port Strike Extended', Los Angeles Times, May 19, 1934, p.A1; 'Strike Laid to Radicals', Los Angeles Times, May 23, 1934, p.A1; Chapin Hall, 'Red-controlled Dock Strike Nearing Crisis', Los Angeles Times, June 4, 1934, p. A1. 253 'Port Strike Crisis Near', Los Angeles Times, May 21, 1934, p.A1; 'Port police Quell Mob', Los Angeles Times, June 12, 1934, p. A1; Hearings on Violations of Free Speech \& the Rights of Labor, Part 64, pp. 23651-2; 'Resolution Demanding the Removal of the Red Squad from the Harbor Strike Area, June 19, 1934, Box 45, Dies/NA. ${ }^{254}$ For more on the raids that followed the strike, see David Selvin, 'An Exercise in Hysteria: San Francisco's Red Raids of 1934', Pacific Historical Review, Vol. 58, No. 3, August 1989, pp. 361-374.
} 
the city of San Francisco was run by workers. Despite the massive outpouring of popular sympathy for labour that the general strike represented, the Industrial Association and other representatives of San Francisco's employers continued to insist that this was the beginning of a communist revolution.

The attempt to find information placing communists at the heart of the strikes was most likely what put employers' associations from Northern California into contact with Van Deman and the sources he had quick access to from San Diego. ${ }^{255}$ On July 2, 1934 Van Deman had received a list of what Commander Hopkins of the ONI called 'the principal agitators' among those taking part in the San Francisco and Bay area strikes. With a red pen Hopkins had underlined for Van Deman all the known party members amongst the strikers. Among the over three hundred names listed were a number of bona fide communists, including Sam Darcy, organizer for district 13 of the $\mathrm{CP}$ and communist candidate for governor. Not underlined was Harry Bridges, the militant Australian chairman of the ILA strike committee. Bridges' entry stated that though 'not a member of the $\mathrm{CP}^{\prime}$, Bridges 'consorted' with party members, and was nevertheless 'very radical'. ${ }^{256}$ For the remainder of the 1930 s members of the California surveillance network, particularly those closely involved with San Francisco employers, would spend a significant amount of effort trying to put a red line under Bridges' name.

In an editorial summing up the strikes, the Times took an exasperated tone, alleging that the strike was called 'without real provocation' over the sole issue of independent hiring halls, completely disregarding the context of the dispute. The newspaper went on to celebrate the heroism of the strike breakers, who 'for the safety of all California [...] served us loyally and faithfully at the daily and hourly risk of your lives' to keep the port of San Pedro open. ${ }^{257}$ Once the strike was over Hynes took a leave of absence from the LAPD, perhaps as a result of the brutality charges filed at San Pedro. Working freelance until April 1935, Hynes served as an anti-labour consultant to several employers' organisations in California, working most regularly with the Associated Farmers, as Carey McWilliams had alleged. Hynes' spent some of this time

\footnotetext{
255 The earliest contact between Van Deman and the Industrial Association found by this author was in May 1935, though the content suggests the likelihood that contact was established some time earlier. For a discussion of this document see footnote 280 in this thesis.

${ }^{256}$ A. A. Hopkins to Ralph Van Deman, July 2, 1934, R-464, Box 4, RHVD/NA.

257 'A Matter of Justice', Los Angeles Times, July 23, 1934, p. A1.
} 
teaching the tactics of anti-labour espionage and strike-breaking, but his main occupation was investigative work-directed at the CAWIU organisers who had caused his employers so many problems over the last year..$^{258}$

On July 20 local police raided the offices of the CP Workers' Center in Sacramento, the administrative headquarters of the party's organising efforts in California. Individuals arrested included Pat Chambers and Caroline Decker, the CAWIU leaders who had organised and supported San Joaquin valley strikers through the summer and autumn of 1933. Along with twelve others they were subsequently charged with Criminal Syndicalism on the basis of their alleged membership in a revolutionary organisation that advocated violence to achieve political or industrial change. Over the next six months Hynes used his contacts and expertise to develop evidence against them, working directly with the Associated Farmers and other members of the surveillance network to bolster the prosecution's case in one of the most important antisubversive trials to take place in California during the 1930s.

When the case came to trial in January 1935, it provided Hynes with another opportunity to make use of the documents collected by the LAPD Intelligence Bureau. In total Hynes contributed from his files almost 300 pamphlets and leaflets on the $\mathrm{CP}$ program in the United States, which formed the basis of the prosecution's case that the CP did in fact advocate the use of violence. Hynes did the same to establish the other crucial aspect of the case-the defendants' CP membership-by submitting CP membership cards (or 'books') for Decker, Chambers, and many of the others. ${ }^{259}$ These twin bases for conviction were the staple of the evidentiary utility of the California surveillance network.

Hynes' evidence was challenged by ACLU attorney Leo Gallagher, assisted by Abraham Wirin and Grover Johnson - the attorneys attacked by vigilantes in the Imperial Valley during 1934. ${ }^{260}$ Though they mounted an impassioned defence based on downplaying the CP's

\footnotetext{
${ }^{258}$ Hearings on Violations of Free Speech \& the Rights of Labor, Part 52, pp. 19071, 19099-100; Hearings on Violations of Free Speech \& the Rights of Labor, Part 64, p. 23572; In a letter to Hynes on June 30, 1934, AFC Executive Secretary Guernsey Frazer brought to Hynes' attention recent statements made by Chambers, Decker, and Albert Hougardy in line with CP publications, the same basis for the prosecution's case in the trial that followed-Letter from Guernsey Frazer to William Hynes, June 30, 1934, Box 45, Dies/NA.

${ }^{259}$ Evidence taken from LAPD records and used in the trial is listed in 'Books, Pamphlets and Publications mentioned in indictment to be used for evidence', Box 45, Dies/NA.

260 Leo Gallagher, like Wirin and Johnson, was a regular target of surveillance efforts.
} 
militarism, abetted in large part by the testimony of the defendants themselves, they faced a jury seemingly convinced of communist malevolence. This perception was aided by testimony from AFC members themselves, such as Frank Peterson, who had been among the group of vigilantes at Pixley who had killed the strikers. According to Peterson, Chambers had urged the strikers at Pixley to violence, forcing the armed growers who had surrounded the assembled audience to fire on the unarmed strikers in 'self-defence'. ${ }^{261}$ Acting on Hynes' advice, the Associated Farmers had also developed a strategy to blanket the press with the material to inflame public fear, generating a localised red scare to further influence the context of the case. ${ }^{262}$

Guernsey Frazer, Executive Secretary of the Associated Farmers of California, was proud of their role in the state's case, privately admitting that his organisation had devoted significant resources to securing the conviction of Chambers and his comrades. As he explained, 'By reason of our contacts and knowledge of the situation we have been able to shape that case, compile the evidence and even assist in the rounding up of material witnesses' ${ }^{263}$ These expenses were extensive. To help him with the case Hynes recruited several other surveillance operatives trained in 'specialised work', including A. A. Hopkins of the ONI and Los Angeles County sheriff's office. For his consultancy services Hynes charged the Associated Farmers \$3700, including $\$ 500$ for Hopkins, plus a few hundred to other parties who Hynes had paid out of his own pocket. ${ }^{264}$

For the AFC, it was money well spent. When the jury returned on April 1 they convicted 8 defendants on the charge of conspiracy to commit criminal syndicalism, including Chambers and Decker, both of whom admitted CP membership but argued that they were being imprisoned for being union organisers, not CP members. ${ }^{265}$ The process used to do so had four main components - the collection of documentation on strike leaders and the Communist Party

\footnotetext{
261 'Rioting Told in Red Trial', Los Angeles Times, February 9, 1935, p 1.

262 Letter from Guernsey Frazer to William Hynes, June 30, 1934, Box 45, Dies/NA; For an account of the results of this campaign in the Sacramento Bee, see Olmsted, 'Quelling Dissent'.

263 Hearings on Violations of Free Speech \& the Rights of Labor, Part 55, pp. 20257-58.

${ }^{264}$ Letter from William Hynes to Parker Frisselle, October 2, 1935, Box 46, Dies/NA; Despite the AFC's wealthy backers, further correspondence between Hynes and the AFC indicate that it took several years for Hynes to be paid for the services rendered in 1934-Letter from Walter Garrison to William Hynes, April 10, 1937, Box 46, Dies/NA.

${ }^{265}$ Chambers and Decker are quoted in Olmsted, 'Quelling Dissent', p. 69.
} 
through surveillance; the use of these documents to link strike leaders with CPUSA membership; the further use of additional documents to establish that the party advocated violent political change; and the application of the membership provisions of the CS law to jail the individuals thereby indicted.

The intended outcome, of course, was not a desire to protect ordinary Californian citizens from communist revolution. Instead, the Sacramento Criminal Syndicalism trial was a legal panacea for labour unrest, purchased by big business from surveillance operatives and their allies in the name of patriotism. In the process, it provided further proof that surveillance, in combination with appropriately punitive legislation, could still be used by employers to disrupt the labour movements that threatened their profits.

\section{Quantifying Surveillance}

Conflicts in the agriculture and maritime industries are one of the several new developments reflected in the changing contents of Van Deman's archive through 1934 and 1935. Chart 2.2 below provides a comparison of the focus of documents in the archive collected during 1932-1933 and in 1935. This comparison partly illustrates the shifts in Van Deman's interests, but given the large amount of material he received from other members of the network it can more accurately be read as an expression of the combined interests of all the contributors to his archive. ${ }^{266}$

\footnotetext{
${ }^{266}$ To produce this graph each ' $R$ ' text in Van Deman's archive for that year was analysed to determine type of text (e.g. surveillance report, police report, correspondence, news article etc.), target of text (Communists, ACLU, pacifists etc.), source of text (as seen in Figure one), geographical scope, and when appropriate, industrial scope. The total numbers of entries corresponding to the most common categories were quantified, and in this case, the result of the relative texts corresponding to the most common geographical and industrial scopes displayed as a whole number.
} 


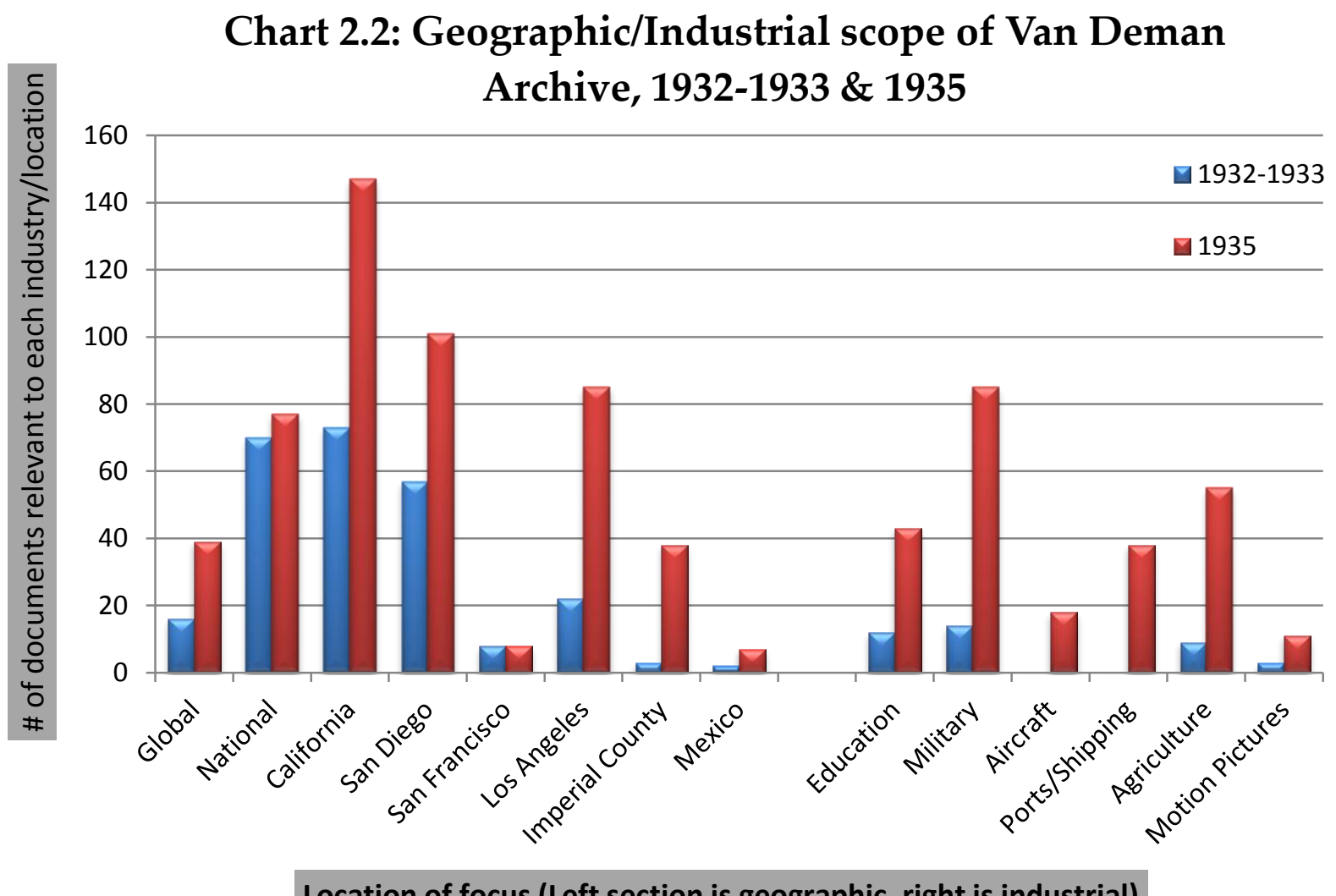

Location of focus (Left section is geographic, right is industrial)

One of the most striking aspects of the analysis presented above is the sheer increase in the volume of surveillance information that Van Deman collected in 1935-from around two hundred and fifty texts in both 1932 and 1933 to over five hundred in 1935 alone. This massive increase is likely a function of the inflamed fears precipitated by the spread of the maritime and agricultural strikes, which created both the demand for more surveillance as well as several new contributors to the archive. As the graph also demonstrates, after 1934 Van Deman's gaze ranged increasingly beyond San Diego to include other locations in California. This expansion of scope could be described as northwards towards Los Angeles, eastwards towards the agricultural areas of Imperial County, and a greater emphasis on activities that affected the state of California as a whole.

Perhaps surprisingly, the dramatic strikes on the waterfront in 1934 failed to hold Van Deman's attention on San Francisco the following year. The reason for this is quite simple-after 1934 the focus of Van Deman and his allies was not to have been on maintaining a vigil over San Francisco itself, but instead on pursuing the leaders of the strike, especially Harry Bridges. Regular information on Bridges flowed to Van Deman for the second half of 1934 and into the following year, until in July 1935 Margaret Kerr of the BAF supplied the most complete report 
yet, which quoted the Los Angeles Examiner as a source alleging Bridges membership in the CP. ${ }^{267}$ During 1935 at least twelve separate documents mentioned Bridges by name as a target. One of these was a partial stenographic account of a Marine Section CP meeting which Bridges' reportedly attended. Sent to Van Deman from G-2, the report quoted Bridges addressing his colleagues as 'comrades', discussing CP strategy for a general strike, and generally directing party strategy among maritime workers on the Pacific Coast. ${ }^{268}$ Proving Bridges' CP membership was akin to a holy grail for many Californian anti-communists and businessmen eager to obtain retribution for the general strike, and an indictment that Northern Californian members of the network in particular pursued with vigour for the remainder of the decade.

Another significant development demonstrated by the above graph was an emphasis on surveillance of key industries or institutions, as opposed to the mostly geographical focus of 1932-1933. Though Van Deman had always been watchful over the spheres of education, the military, and agriculture, 1935 saw a sharp increase of attention paid to these particular areas. These increases reflect the widespread concern about the effects of $\mathrm{CP}$ infiltration, organisations and agitation among sympathetic workers in these fields after the dramatic labour unrest of 1934.

In total Van Deman collected at least forty-three documents relating specifically to the field of education in 1935, compared with only twelve in 1932 and 1933. This rise in attention was often centred on the National Student League, a communist front organisation which succeeded in organising tens of thousands of students across the country in anti-war protests that took place in April of both 1934 and 1935. Van Deman had an undercover informant in the organisation who sent him regular updates on their meetings and personnel over the course of 1935. ${ }^{269}$ Another regular focus in this area was the ongoing pursuit of radical professors or 'parlor pinks' such as San Diego State College's Harry Steinmetz. ${ }^{270}$ Steinmetz was surveilled by Van Deman and his allies for several years-especially by anti-communist lawyer, National

\footnotetext{
267 'Harry Bridges’, c. July 21, 1935, R-1010, Box 7, RHVD/NA

268 Partial Stenographic notes from Marine Section CP meeting, October 8, 1935, R-1097, Box 7, RHVD/NA.

${ }^{269}$ For examples, see 'Radical Activities', February 26, 1935, R-803c, Box 6, RHVD/NA; 'Radical Activities', April 2, 1935, R-826b, Box 6, RHVD/NA; 'Summary of subversive statements made at Memorial Day Symposium against War and Fascism', May 30, 1935, Box 6, RHVD/NA.

${ }^{270}$ For examples, see Claude Coldren to Mrs. Ulrich von Buelow, May 8, 1935, R-934a, Box 6, RHVD/NA; 'Officer's report concerning Communist Activities', December 12, 1935, R-1187, Box 8, RHVD/NA.
} 
Guard colonel and fellow legionnaire George W. Fisher, who would continue Van Deman's archival work after the spymaster's death in 1952. ${ }^{271}$ Another informant was a Mrs. Ulrich Von Buelow, likely a faculty member herself, who in November 1934 sent Van Deman a detailed report on various faculty members suspected of radical beliefs at the campuses of UCLA and USC. ${ }^{272}$

By 1935 collaboration between local anti-communists in San Diego had increased to the point where ONI operatives were regularly accompanying SDPD officers to social functions of the San Diego Communist Party. At dances attended by upwards of two dozen teenage leftists, there might be assigned four SDPD or ONI agents, who invariably reported the attendance of any military personnel. Van Deman's seemingly open access to the investigative reports of both the ONI and the SDPD accounts for the large number of documents concerning communist infiltration of the military across California - at least eighty-five in 1935 compared with fourteen in 1932 and 1933. A letter from W. V. Michaux of the ONI discusses Van Deman's role in this operation as 'liaison work', suggesting that informal assent was given for Van Deman to share confidential military secrets under a limited mandate. ${ }^{273}$ Van Deman's former role as commander of the Sixth Infantry Brigade at Fort Rosecrans offers a parallel justification for the large increase-on a personal level, Van Deman was highly concerned about the condition of the U.S. armed forces, particularly the ideological condition of young recruits. ${ }^{274}$ Thus $\mathrm{CP}$ and pacifist efforts to undermine the military were a recurring target of Van Deman's enquiries.

Other operatives in Southern California were similarly concerned, and cooperated often to determine who was behind the distribution of the communist Shipmate's Voice. This may have been because of overlapping personnel or spheres of interest, such as in December 1935 when an allied anti-communist organisation called the Long Beach Civic Council of Defense [CCD] sent Van Deman a report describing the distribution of the communist publication on board the

\footnotetext{
${ }^{271}$ In 1954 Fisher finally succeeded in getting Steinmetz fired from his academic position after two decades collecting surveillance on his speeches and political activities. For an account of Steinmetz's dismissal see-Paul Eisloeffel, 'The Cold War and Harry Steinmetz: A Case of Loyalty and Legislation', The Journal of San Diego History, Vol. 35, No. 4, Fall 1989, accessed 11/10/14 from http://www.sandiegohistory.org/journal/89fall/cold.htm

272 Report re-Communistic Activities, c. November 1934, R-695, Box 5, RHVD/NA.

${ }^{273}$ W. V. Michaux to Van Deman, April 5, 1935, R-836, Box 6, RHVD/NA.

${ }^{274}$ For examples see-'Officers Report concerning Communist Activities', June 22, 1935, R-972, Box 7, RHVD/NA; 'Officers report concerning Communist Activities', April 13, 1935, R-840, Box 6, RHVD/NA; Van Deman to ONI \& SDPD, April 16, 1935, R-839a, Box 6, RHVD/NA.
} 
USS Utah, then docked at the port of San Pedro. The pamphleteers were detained by law enforcement, and then interrogated by Long Beach police sergeant Tom Wishon. As well as being an LBPD officer, Wishon was an 'agent on the zone staff' of the ONI, and one of the leaders of the CCD as well. ${ }^{275}$ The report that the CCD sent to Van Deman thus contains reports on surveillance collected from all of those organisations, as well as from Hynes of the LAPD. ${ }^{276}$

The rise in documents focused on the agricultural industry, and on Imperial County in particular, demonstrates that attention paid to that conflict by members of the surveillance network. Some of the documents collected in that area reflect the sophistication of groups such as the Associated Farmers. For example, a January 1935 letter to Van Deman from AFC executive secretary Guernsey Frazer reveals that the group were trying to discover and disrupt the resources of the organisations defending farm labour. One way they did this was through surveillance and public attacks on the Garland Fund, a New York-based organisation which provided large amounts of money for leftist causes. An accompanying report on the fund's expenditure reveals that the organisation donated \$35,491 to 'Legal Defense' trial costs in 1934 alone, and over $\$ 50,000$ to the ACLU and ILD in forfeited bail, publicity campaigns and court costs. ${ }^{277}$ Such a strategy is a testimony to the composition of the Associated Farmers executive, many of whom were drawn from the elite of Californian businessmen-a point which their opponents pointed out regularly to deny the credibility of the organisation's claim to represent the interests of farmers.

Chart 2.3 below compares the amount of attention paid to the ten most commonly surveilled targets in Van Deman's archive through both 1932-33 and 1935. ${ }^{278}$

\footnotetext{
275 Surveillance operatives such as Wishon often held membership in overlapping or interlocking organisations. Membership in the American Legion, for example, was a common feature of almost every participant in the California surveillance network, while many who occupied public positions in law enforcement or the civil service supplemented their government incomes by periodically working for private organisations.

276 'Report on Shipmates Voice', December 12, 1935, R-1195, Box 8, RHVD/NA; Also see-Tom Wishon, 'Report on Bonus March', c. May 1935, R-1015, Box 7, RHVD/NA. In this interesting report on the 1935 Bonus March Wishon is identified as the author in a handwritten note by Van Deman.

277 Guernsey Frazer to Van Deman, January 28, 1935, R-784a, Box 6, RHVD/NA.

${ }^{278}$ To produce this graph, the results of textual analysis of all of the documents preserved in VD's archive for that year were entered into a database. In this case, the documents were analysed according to the target(s) each text pertained to, and then quantified as a total for the group of years. An undercover surveillance report of a communist party meeting, for example, would be simple to classify because of the clear target of surveillance. However many documents featured more than one target, necessitating the recording of multiple targets for a single text. For example, a surveillance report might record the names of all the delegates at a $\mathrm{CIO}$ convention,
} 


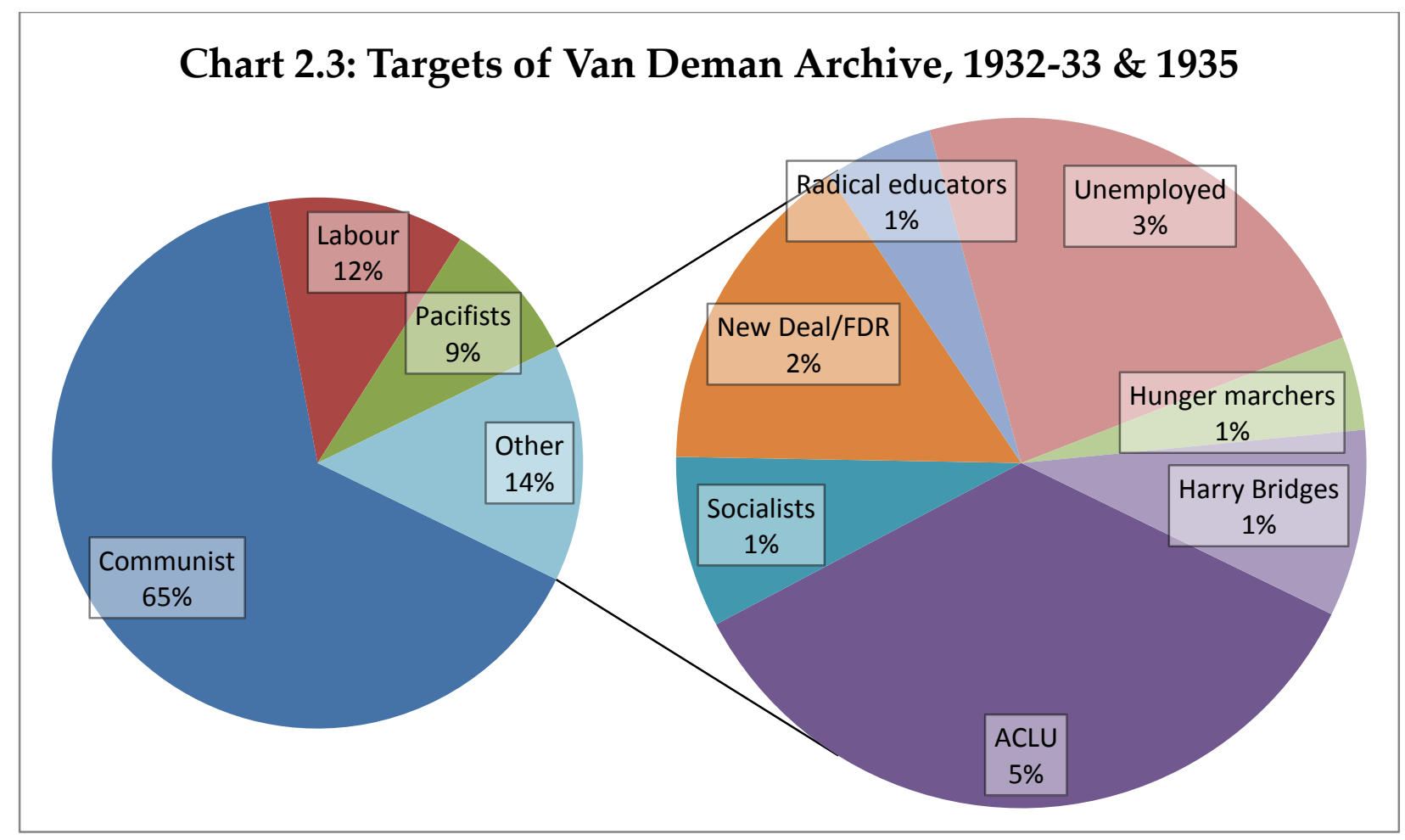

As the above graph demonstrates, until the end of 1935 the attention of Van Deman and his surveillance partners was overwhelmingly targeted towards suspected or actual members of the CPUSA. In fact, approximately sixty-five per cent of all documents collected featured communists as a target. During these years both labour and pacifists were the most significant secondary targets, featuring in twelve and nine per cent of texts respectively. Though labour surveillance does not seem to have been a direct aim of Van Deman's, it was for other members of the network-particularly new contributors such as the Associated Farmers and Industrial Association with whom he began sharing information in 1935. Pacifism on the other hand was a philosophy that Van Deman was diametrically opposed to - with almost all of the surveillance texts targeting pacifists submitted by his own informants, or by his military sources at the ONI and G-2. Of the remaining fourteen per cent, the most frequent targets of surveillance were the ACLU, the unemployed, and President Roosevelt or New Deal agencies, groups under suspicion because they were either seen as sympathetic to communism or vulnerable to infiltration by its operatives.

with a further notation indicating CP members among those delegates. In such a case, both ' $\mathrm{ClO}$ ' and 'Communist' would be recorded as targets. In order to avoid giving an inaccurate impression of the total number of texts as a result of these double (or triple) entries, these results were expressed as a percentage rather than as whole numbers. 


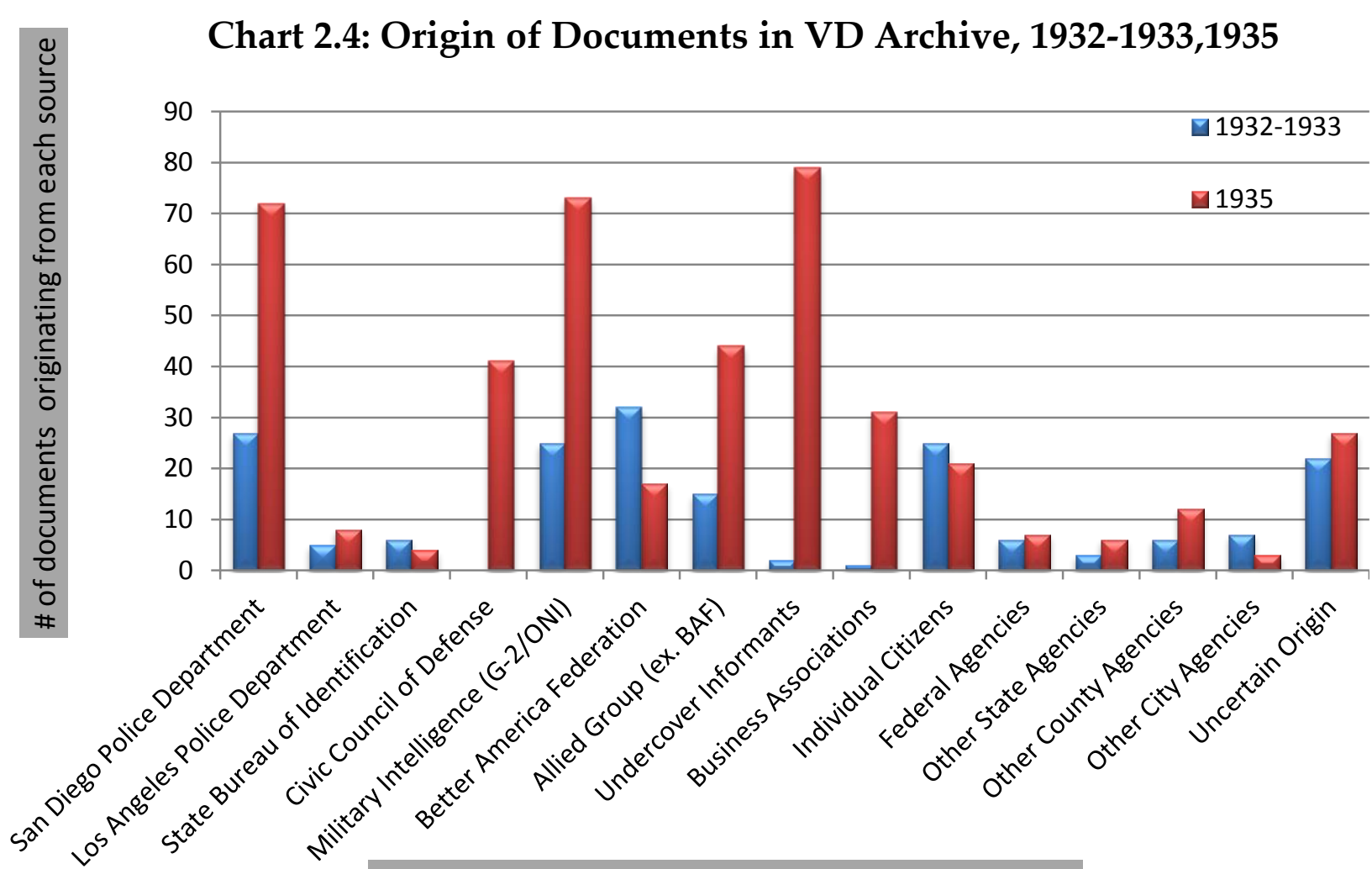

Institutional affiliation of contributors to VD Archive

Chart 2.4 above compares the sources of Van Deman's intelligence in 1932-33 and 1935. The most dramatic quantitative change expressed in the above graph is the massive growth in the amount of information Van Deman archived from undercover informants, from only two in 1932 and 1933 to seventy-nine documents in 1935 alone. In some of these texts the motivations, employers and agendas of undercover informants are deliberately obscured through coded designations, vague allusions to other events, and other means. ${ }^{279}$ However, often these agendas are revealed in the texts themselves.

This was the case for example in May 1935, when Van Deman received from an undercover operative for the Industrial Association a surveillance report on the Workers School

\footnotetext{
279 In later years the desire to obscure their activities became worthy of the hoariest espionage clichés. In one letter to operatives of the Industrial Association and the American Legion, the sender used a letter substitution cypher to hide his message. The message was decoded by this author with the assistance of a colleague. With spaces, punctuation, and some minor corrections added, the letter reads-'I will be on western pacific number one arriving Wednesday tomorrow. Get me small apartment, weekly rate bay area where [I] can work undercover yet get out. Notify me telegram re Thompson. Care conductor so can arrange have baggage off place picked or meet me enroute. Notify Frances where i will be and tell her to join me. Sent to Dazey and Knowles. Henry. Tell [B]arker nothing'. For the coded original, see 'Myd' to Harper Knowles, June 28, 1938, Box 1, California Surveillance Collection, Labor Archives and Research Center, San Francisco State University, [Hereafter referred to as CSC/SFSU]. Other operatives, included Van Deman, used invisible ink on occasion.
} 
of Los Angeles. Instructed to enrol in courses at the school to determine the scope of the school's curriculum, the IASF's operative reported back that the published program of classes was radically different to the curriculum held by the school's executive board. According to the agent's report, this 'secret' curriculum was fundamentally designed to teach communist political and organizing theory. This included the teaching of a class on the 'Problems of the Pacific Coast', at which time students would also be instructed on 'how to prevent war preparations', 'how to fight vigilantism', and 'how to organize a general strike'. ${ }^{280}$ These activities clearly brought it within the sphere of interest of the Industrial Association, which often engaged in surveillance to determine the extent of $\mathrm{CP}$ participation in the San Francisco strikes the previous year. The fact that this particular surveillance was directed at a target in Los Angeles demonstrates the organisation's reach, and its commitment to disrupt any future activities that might harm its interests.

All of the major surveillance groups shared a predilection for undercover informants, including the IASF and the AFC, the network's newest participants. Both became regular contributors of intelligence information to Van Deman in 1934, and both were similarly engaged with other surveillance operations throughout California as well as with Van Deman himself. ${ }^{281}$ Often the CCD would act as a conduit to channel information from these Northern Californian organisations. For example, in May 1935 Van Deman was sent information via the CCD gathered by informants working for the Associated Farmers on Sumner Dodge, an individual the AFC suspected was posing as an anti-communist in order to gain information on their own operation. $^{282}$ Their role as conduit for these new contributors to Van Deman meant that the CCD in 1935 temporarily supplanted the BAF as Van Deman's most prolific suppliers of information from a group outside of government. Compared to the seventeen documents sent to Van Deman by the BAF in 1935, the CCD supplied forty-one. ${ }^{283}$

\footnotetext{
280 Surveillance Report on the Workers School of the Communist Party, May 22, 1935, R-135, Box 6, RHVD/NA. 281 The AFC began sending information to Van Deman in August 1934. See-R-757a, Box 5, RHVD/NA. Both groups communicated regularly with all the major Californian surveillance organisations represented in Van Deman's archive. These included the LAPD, the SDPD, the BAF, the CCD, the ONI, and of course each other.

282 Dorothy Dean to Van Deman, c. May 1935, R-948, Box 6, RHVD/NA; Also see-Report on Peter V. Armstrong, June 19, 1935, R-967a, Box 6, RHVD/NA.

${ }^{283}$ Very little information is available on the CCD, though documents in the VD archive strongly suggest that the CCD was a surveillance and patriotic organisation formed by Long Beach Police Department and other civic personnel to aid their vigil over the port of San Pedro. Their member publications were sent to Van Deman on
} 
Van Deman also cultivated a stable of undercover informants. The most regular and adaptive of these identified himself in letters as HA77, while Van Deman referred to him as B11 in some unknown rubric that was also applied to other operatives. ${ }^{284}$ On December 30, 1934 B-11 phoned Van Deman at his home to report his recent activities as an undercover member of the $\mathrm{CP}$ program to target sailors for propaganda operations. After reporting on the movements of his comrades, Van Deman phoned SDPD and the ONI to report the information. In the expectation that the $\mathrm{CP}$ members might be arrested while in the act Van Deman told contacts in both agencies the cover name his informant would give if arrested. In none of these communications did Van Deman report B-11's true identity, which strongly suggests that B-11 was an agent that personally reported only to Van Deman. ${ }^{285}$ In December 1935 B-11 reported to Van Deman from an undercover assignment in the Imperial Valley that he had become personally sympathetic towards agricultural workers in the Imperial Valley. Rather than considering their plight to be an effect of the low wages and harsh conditions workers were forced to endure, B-11 blamed the $\mathrm{CP}$ for their organising efforts, which he claimed were forcing reluctant workers into conflict with vigilantes representing agricultural interests.

These professed sympathies did not prevent B-11 from attempting to manufacture tensions between workers, their unions and the AFL to disrupt their attempts to organize. In order to deny one Imperial Valley union an AFL charter B-11 intercepted their communications to sow confusion, while deliberately misinforming union leaders that communists were trying to gain control of the union through the AFL charter offer. He also employed measures to inflame racial tensions amongst the workers, telling Mexicans that white workers and communists were trying to exploit them, while suggesting to Van Deman that if 'thru some

occasion, and record much of the organisation's character, which somewhat resembled the BAF. The CCD was quite social as well, regularly hosting speakers who were contributors to the California surveillance network or otherwise notable public figures, such as Imperial County district attorney Elmer Heald, and San Diego deputy district attorney Edward Goodman, who spoke on the ACLU legal challenge to the San Diego board of educationCivic Council of Defense, 'Office News', April 16, 1935, R-852, Box 6, RHVD/NA; Civic Council of Defense, 'Office News', May 16, 1935, R-950, Box 6, RHVD/NA.

${ }^{284}$ Other informants encountered in Van Deman's archive used ' $A$ ' prefixes up to the number ' 43 ', while there were also a few other ' $B$ ' operatives. It is also highly likely from the nature and scope of the information submitted that the ' $A$ ' informants worked for the SDPD or ONI. The sources whose code began with the letter B (such as B-10, B-11, B-15, and B-31) worked for Van Deman directly, though this is difficult to verify.

${ }^{285}$ Van Deman, Memorandum on phone conversation with B-11, December 30, 1934, R-727a, Box 5, RHVD/NA. The same conversation reports that when Van Deman called SDPD to report the call, 'A-15' answered. This in turn suggests that at least some ' $A$ ' agents were members of the SDPD. 
secret channel, the Phillipinos could be prevailed upon to mistrust the Mexicans and to NOT join with them, there would be little likelihood of the organization growing'. ${ }^{286}$ By the end of the month the agent reported the success of his endeavours, concluding that 'the various factions can be kept in dispute and they will make little headway' as a result.

B-11 earlier had reported information from a 'Spanish comrade from Salinas' that Mexican communists had stolen a large cache of dynamite from the town of Calexico. According to the informant, the dynamite would be used against packing sheds in the Imperial Valley, and also to prevent growers there from protecting themselves against strikers. Van Deman sent copies of the document to ONI and Captain Macy of the SDPD, and would have passed this information on to Imperial Valley authorities as well, but a handwritten note indicates that the informant (codenamed B-11) had contacted Imperial County deputy sheriff Rodney Clarke of his own volition. ${ }^{287}$ A week later Clarke announced a renewed 'War on Reds' in the Valley. This 'roundup of professional agitators, Communists and suspects' was claimed by Clarke to be a response to rumoured acts of violence during the lettuce picking season that was then underway. ${ }^{288}$ Based on two rumours, both supplied (and one manufactured) by B-11, the sheriff revealed to the Times specific plans to dynamite packing sheds, and of communist attempts to organize field workers under an AFL charter. With this small exposure of surveillance information another tiny Red Scare was created, and another cycle of repression began in the agricultural fields of California.

\section{Conclusion}

The Fish Committee's hearings in Los Angeles provided a useful mobilising vehicle for the BAF and the LAPD at the beginning of the 1930s, and concurrently, an outlet for the collected surveillance information and categories of suspicion they had developed during the 1920s. Together, they participated in an apparatus of exposure which placed before the public

\footnotetext{
${ }^{286}$ Surveillance report on Communist Activities in El Centro, December 24, 1935, R-1203, Box 8, RHVD/NA.

${ }^{287}$ Report from undercover informant re: Agriculture, December 16, 1935, R-1191, Box 8, RHVD/NA.

288 'Imperial County Launches War on Reds to Balk Lettuce Strike', Los Angeles Times, December 31, 1935, p. 8.
} 
sensational evidence of the communist conspiracy that threatened the nation, while offering legislative solutions to the problem that inevitably contained all the prejudices and politics of those who had identified the threat.

The Fish committee exposures represented a significant mobilisation of the Californian right, which was further encouraged by their opposition to the federal mandates on the state's economic recovery imposed after 1932. Partly as a result, between 1930 and 1935 a network of surveillance organisations formed to collect and share information on the radical population of California. They also shared personnel, as demonstrated when Hynes of the LAPD took his leave of absence to advise the Associated Farmers on strike-breaking tactics in the Imperial Valley and trial preparation in Sacramento. Other members of the network were involved in multiple participating organisations at once, such as A. A. Hopkins of the ONI and LA Sheriff's office, or Tom Wishon of the Long Beach Police Department, ONI, and Civic Council for Defense.

Ostensibly fighting communism, members of the network also participated in widespread anti-labour espionage, most spectacularly in the Imperial and San Joaquin Valleys, where employers directed the supposedly 'grassroots' Associated Farmers in vigilante actions against strikers and the communist organisers who were attempting to organise them. Following the format used in the Imperial Valley trial at the beginning of the decade, law enforcement and employers also pursued high-profile legal remedies to the problems presented by the renewed strength of the labour movement.

This was the format followed in the Sacramento Criminal Syndicalism trial in 1935. That trial, and its successful outcome, again demonstrated the value of surveillance collection as a tool to disrupt labour movements by targeting their leaders. Hynes' role in the trial as a consultant to the Associated Farmers further vindicated the approach he had developed in 1930, while also offering a potential solution to the problem of the other major industrial dispute of 1933-1934-the maritime strikes, which proved to be a more challenging proposition. 


\section{CHAPTER 3: EXPOSURE (1936-1939)}

I would have worked with the devil himself if he'd been for the six hour day and worker control of the hiring hall-Harry Bridges, ILWU and CIO leader, 1939.289

In the late 1930s California's surveillance network gained congressional allies to help them achieve a goal some members had pursued since the waterfront strike in 1934-the deportation of Harry Bridges and the curbing of the militant labour movement which he represented. Ultimately the clashes between left and right through the vehicles of competing Senate and House investigative committees exposed to a nationwide audience the activities of the Californian surveillance network, and the counter-surveillance conducted by their targets.

Bridges served as a symbol of the Red menace to California conservatives due to his role in the waterfront strike conducted by the International Longshoremen's Association [ILA] in 1934. The strike punctuated a dramatic rise in labour activism which, in turn, sparked increased employer anti-union activity and prodded the CP to change its strategy-a switch in the party line from encouraging the formation of radical union competition with the mainstream labour movement towards organising within existing AFL unions and participation in a broad coalition to push the New Deal leftward. ${ }^{290}$ The result was an influx of CP organisers into existing union structures, particularly the AFL. In 1935 the Seventh Congress of the Communist International gave its official endorsement to the new direction by declaring the need for a popular 'People's' front to fight fascism internationally.

In the United States, this strategy resulted in closer cooperation between CP members and other organisations, especially more moderate labour, pacifist, anti-fascist, and civil rights groups. California's surveillance network paid attention to this change in strategy, giving greater emphasis to the identification of links between suspect individuals and organisations. In the view of anti-communists, the CP's strategy confirmed the claims made since 1917 about the

\footnotetext{
${ }^{289}$ Harry Bridges, 'The Harry Bridges Project-The One-Man Play', accessed 14/02/14 from http://theharrybridgesproject.org/theplay.html ${ }^{290}$ Fraser M. Ottanelli, The Communist Party of the United States: From the Depression to World War II, (New Brunswick: Rutgers University Press, 1991), pp.49-80
} 
danger of CP infiltration into radical and reform groups. For California's surveillance coalition, the development of a popular front expanded the categories of suspicion through which to target the left, previously expressed publically through BAF newsletters, criminal syndicalism trials and the Fish Committee's hearings.

The July 1935 passage of the National Labor Relations Act [NLRA] reinforced the CP's union strategy by providing federal protection for the right to bargain collectively through National Labor Relations Board [NLRB] rulings requiring employer recognition of unions after certification by the NLRB. The subsequent creation of the Committee for Industrial Organizations [CIO] within the AFL in late 1935 created a new bulwark for radicals within the labour movement, alarming the business community. Aided by left-wing militants CIO unions began new organising efforts in aircraft, agriculture, automobile, oil, film, and other industries vital to the state's economy. Though the threatened AFL leadership decided to expel CIO unions in 1936, the newly independent organisation continued to grow, encroaching on the same Californian industries which the surveillance network had successfully defended in the early 1930 s.

Just as Roosevelt's overwhelming victory in November 1936 cemented the New Deal's grip on power, the ILA began another major strike on the Pacific coast which lasted until February 1937. Out of that dispute Bridges led west coast locals out of the ILA into the CIO, becoming the International Longshoremen's and Warehousemen's Union [ILWU]. Already fearful of Bridges' control of the ports, Californian business owners watched as the $\mathrm{CIO}$, aided by $\mathrm{CP}$ organisers and sympathetic New Deal legislation, continued to build their strength in transportation, agriculture, and other vital industries. Conservative fears that Bridges represented a significant threat to Californian business fuelled a campaign to deport the Australian-born labour leader conducted by key members of California's surveillance network. In 1938 the CIO regrouped as the Congress of Industrial Organizations, formally constituting itself as a rival federation outside of the $\mathrm{AFL}$, and a powerful radical alternative to that organisation's long control over the American labour movement.

Simultaneous to the CIO's consolidation of power the Senate Subcommittee Investigating Violations of Free Speech and the Rights of Labor was formed. Informally called the La Follette Civil Liberties committee after its chairman Senator Robert La Follette, Jr., it began with the 
encouragement of NLRB staff to investigate employer resistance to unions. Committee investigators arrived in California in 1938. Focusing especially on anti-union activities in agriculture, committee investigators uncovered widespread evidence of cooperation between employers' organisations, surveillance operatives, vigilante groups, and law enforcementconcluding that all were deliberate participants in a systematic and illegal campaign to prevent successful unionisation.

A response from the right was inevitable, and in 1938 the La Follette Committee faced a rival House investigation undertaken by the Special Committee on Un-American Activities, chaired by Representative Martin Dies. Formed in 1938 by members of an emerging anti-New Deal coalition, the Dies Committee sought to check the power of the $\mathrm{CIO}$ by investigating and publicising allegations of Communist Party control over CIO labour unions and the New Deal administration. Among its allies were disgruntled members of the AFL, which resented the growing influence of the rival group. ${ }^{291}$ The committee immediately sent an investigator to California to meet with members of the surveillance network, where a strategy was developed to secure the deportation of Bridges, who they believed to be personally responsible for the upsurge of labour militancy in California.

These two committees worked to construct competing narratives about the threats facing the American public. The symbiotic relationships they each shared with California-based witnesses, allies, and contributors helped both committees gain funding from the Senate or the House and attract publicity to use against their targets. By 1938 the conservative counteroffensive had begun to take its toll however, and by the end of the year the La Follette committee found itself increasingly isolated and unable to secure the funds it needed. Blocked by a hostile Republican congress and in competition with the Dies committee for appropriations, exasperated committee investigators turned their files over to local allies in the hope they might find an alternative public outlet.

In July 1939 lawyers defending Harry Bridges from deportation charges took advantage of the public opportunity that the La Follette committee was yet to receive, exposing parts of the California surveillance network as participants in a conspiracy to manufacture charges against

291 Jennifer Luff, Commonsense Anti-Communism: Labor and Civil Liberties between the World Wars (Chapel Hill: University of North Carolina Press, 2012), pp. 162-95 
their client. In what was seen by many commentators as a mini-La Follette investigation, attorneys Carol King, Richard Gladstein and Aubrey Grossman revealed the concealed machinations of West Coast employers and their surveillance operative allies to locate and secure evidence that might be used to prove the ILWU leader's CP affiliations.

In the second half of the 1930s California's political environment was moving against the nationwide trend to the right. Although it had defeated Upton Sinclair's challenge in 1934 California's Republican Party lost the 1938 elections, giving left-wing Democrats control of the state government. Democratic Governor Culbert Olson publically welcomed the La Follette investigation, while in Los Angeles sweeping reforms of the city government began after two officers from the LAPD Intelligence Bureau had fumbled an attempt to murder an investigator from a citizens' anti-corruption organisation. The ensuing scandal prompted a recall election, replacing Mayor Frank Shaw with Fletcher Bowron who vowed to clean up the city administration. In the wake of that vow LAPD Chief James E. Davis retired, and his successor closed the LAPD Intelligence Bureau, reassigning Hynes to patrol duties. The simultaneous loss of political power by business-friendly conservatives at the state and city levels made business interests even more reliant on the surveillance network, their own resistance methods, and the Dies Committee to curb the resurgent labour movement and its radical allies in government.

\section{The Duelling Committees}

The National Labor Relations Act, or Wagner Act, passed into United States law on July 5, 1935, essentially replacing the 1933 NIRA law which had been declared unconstitutional by the Supreme Court two months earlier. The new law protected the rights of most employees in the United States to organize into unions, to bargain collectively, and to be treated fairly by their employees while doing so. Though a major achievement for the New Deal coalition the act was far from universal-gaining the necessary legislative support of Southern Democrats had required concessions, leaving notable sections of U.S. labour exempt from the law's provisions. This exclusion applied to agricultural workers and domestic servants, both industries dominated by ethnic minorities, particularly in the South. The exclusions made the Wagner Act 
palatable to those representatives concerned that it might undermine Jim Crow segregation via the backdoor of labour and collective bargaining protections. Since many unions, particularly in the AFL, held de facto policies excluding black Americans from their membership anyway, the passage of a neutered Wagner Act would ensure that the racial status quo would be maintained by the exclusions while still protecting the majority of white workers. As a result, workers of every colour within the Californian agricultural industry were left without the collective bargaining rights granted to those in other industries.

The new law was enforced by the National Labor Relations Board [NLRB], created in a different guise two years earlier by the NIRA. In its first year of operation, the NLRB identified serious and systematic violations of the Wagner Act throughout the country but faced significant opposition from employers' representatives, who launched a series of legal challenges to the constitutionality of the Wagner Act. Exasperated, board members turned for help to Progressive Party Senator Robert M. La Follette, Jr., imploring him to introduce a resolution in the Senate calling for an investigation. If successful, the resolution would establish a Senatorial committee with the ability to hold public hearings, hear witnesses and issue subpoena's compelling employers to provide the committee with evidence. This would provide the NLRB with a means around the injunctions restricting their work-a public forum for the information they had already gathered on the anti-labour activities of American employers. ${ }^{292}$

Around the same time La Follette received a similar appeal from civil libertarians concerned about a widespread and growing trend towards the restriction of freedoms of speech, association, and assembly. The ACLU and other groups argued that these constitutional rights were being systematically and frequently violated. Though the ACLU had a variety of concerns, 'the attack on workers' rights' had been the dominant issue for the organisation over the previous year, which 'far outdistanced any other aspect' of their work. ${ }^{293}$ Though critical of the government's inaction so far, the ACLU believed that the only recourse to so dire a situation was governmental intervention, and so they too appealed to Senator La Follette.

\footnotetext{
292 Jerold S. Auerbach, 'The La Follette Committee: Labor and Civil Liberties in the New Deal', Journal of American History, Vol. 51, No. 3, December 1964, pp. 435-59.

${ }^{293}$ ACLU, 'Land of the Free: The Story of the Fight for Civil Liberty 1934-35', June 1935, R-735a, Box 5, RHVD/NA.
} 
The resulting Senate Resolution 266 was an amalgam of these overlapping concerns. As La Follette explained, 'the most spectacular violations of civil liberty [...] have their roots in economic conflicts of interest $[\ldots]$ association and self-organization are simply the result of the exercise of the fundamental rights of free speech and assembly'. ${ }^{294}$ By linking these concerns the committee was premised from the outset that attacks on collective bargaining, protected in theory by the Wagner Act and NLRB but challenged by employers, represented a violation of constitutional rights. Passed on June 6, 1936, the resolution created the Subcommittee Investigating Violations of Free Speech and the Rights of Labor. It was staffed by a number of NLRB lawyers and other civil libertarians representative of those who had worked towards its creation. This injection of experts provided the committee with a base of existing knowledge about employer violations of civil and labour rights, while staff received a vehicle to place the results of that research into a public forum.

For its first two years the La Follette committee worked to investigate the use of industrial espionage and strikebreaking tactics in the United States. It gained national publicity for these revelations, particularly its findings on the use of private detectives by employers - a practise it claimed was so widespread as to be almost ubiquitous in every medium-sized factory. However, despite the national attention drawn to Californian labour conditions after the agricultural strikes in the San Joaquin and Imperial Valleys, the La Follette committee spent its first two years focused on conditions in eastern and southern states. It was not until the second half of 1938 that the committee began turning its attention westwards, where the NLRB had set up to help investigate the efforts of employers' groups to maintain the open shop and prevent successful unionization of California's vital industries. By then the subcommittee was rapidly running out of funds. At the same time a rival committee was organising, one opposed to the New Deal and especially to the government's encouragement of labour organisation through the NLRB and the La Follette committee.

Passed on May 26, 1938, House Resolution 282 created the Special Committee Investigating Un-American Activities, then a temporary entity that after WWII would evolve into the powerful standing committee known as HUAC. Dies assigned Edward Sullivan, a

${ }^{294}$ La Follette quoted in Auerbach, pp. 442-3. 
former labour spy, the task of conducting the preliminary investigation of California. ${ }^{295}$ En route to California Sullivan met with Chicago anti-Communist Harry Jung, who provided him with a list of people 'who could furnish valuable leads on un-American activities' on the Pacific Coast. 296 The list included Hynes and Van Deman, as well as Raphael P. Bonham, an Immigration and Naturalisation Service [INS] official who had been publically campaigning for Bridges' deportation earlier in the year. It also included Harper Knowles, an investigator for both the Associated Farmers and the California American Legion's Radical Research Committee. ${ }^{297}$ Over the next month these individuals provided Sullivan with the surveillance they had been assembling on the perfect target for the committee's public hearings - a radical labour leader who had led West Coast unions into the CIO, who enjoyed close ties with several New Deal-associated government agencies and personnel, and who was alleged by his critics to be a high-ranked member in the CPUSA. That target was Harry Bridges, the Australian longshoreman who had become a national labour leader after the San Francisco maritime strikes.

Though a campaign to deport Bridges had begun in the immediate aftermath of the 1934 strikes, his antagonists had previously lacked sufficient legal grounds to induce the government to take public action against him. ${ }^{298}$ That apparently changed early in 1938, when an investigation into the merchant marine by New York Senator Royal Copeland received reports of Bridges' membership in the CPUSA. Soon afterwards Copeland contacted Bonham, and the two began applying pressure on the Department of Labor to investigate Bridges for possible deportation proceedings. By that time the leader of the San Francisco waterfront strikes had been elected president of the International Longshoremen's and Warehousemen's Union [ILWU]-which he had formed from ILA rank and file members loyal to him-and western director of the CIO. Margaret Kerr of the BAF contributed to Copeland's efforts by sending him an affidavit in February from one of the BAF's undercover informants-a man who claimed to have first-hand knowledge and documentary evidence of Bridges' party membership. Copeland

\footnotetext{
295 “Maps Wide Enquiry Into Propaganda”, New York Times, June 19, 1938, p. 26.

296 Jung was an infrequent contributor of information to Van Deman's archive, and an active collaborator with the BAF and the CCD. For examples, see R-950; R-967c, Box 6, RHVD/NA.

${ }^{297}$ Edward Sullivan to anon., June 28, 1938, Box 11, Dies/NA.

${ }^{298}$ For an account of this campaign from the perspective of the Waterfront Employers Association, see Howard Kimeldorf, Reds or rackets?: The making of Radical and Conservative Unions on the Waterfront, (Berkeley: University of California Press, 1992).
} 
passed this affidavit to the Department of Labor, forming the heart of the government's case for the deportation proceedings that looked increasingly certain.

After a long campaign of public pressure, deportation charges were finally brought against Bridges on March 5, 1938. The warrant accused Bridges of 'belonging to an organization which advocates overthrow of the government by force and violence'. ${ }^{299}$ A Los Angeles Times editorial on March 8, 1938 suggested that Secretary of Labor Frances Perkins should be tried as well-arguing the fact that Bridges would be the first alien radical brought to trial during her tenure was proof of both her incompetence and a lacklustre commitment to fighting communism. ${ }^{300}$ The deportation hearing was set for April 25, but delayed repeatedly after a deportation trial in a Louisiana federal court found CP membership insufficient grounds for deportation. Then on June 17 Senator Copeland died, which stalled the project completely. Without Copeland the campaign to deport Bridges lacked a legislative sponsor prepared to push against a Department of Labor unable (or unwilling) to pursue charges against Bridges. Patriotic organisations and the Times were outraged by the sequence of delays, charging that Perkins and her department were deliberately sabotaging the procedure out of sympathy to Bridges. ${ }^{301}$ Though it seemed that momentum had been lost, Kerr and the BAF would not have to wait long before the Dies committee would come forward to offer their support, acting as official patrons for the anti-Bridges coalition that continued to maintain public pressure for his deportation.

Sullivan arrived in Los Angeles on July 1, 1938, a week before the committee held its first hearings in Washington. Travelling under the pseudonym 'Tom Brown', Sullivan was met at the Los Angeles train station by Captain Hynes, who arranged a car and driver for Sullivan as well as office space in the state building, from where Sullivan later moved to the same building as the Intelligence Bureau. ${ }^{302}$ On July 3 Sullivan met with the English actor Victor McLaglen, who advised the investigator about communist activities within the film industry. ${ }^{303}$ Over the next few days Sullivan made arrangements with the committee to furnish transportation for

\footnotetext{
299 'Red Trial set for Bridges', Los Angeles Times, March 6, 1938, p. A9.

300 'Try Bridges-and Perkins!', Los Angeles Times, March 8, 1938, p. A4.

${ }^{301}$ Warren Francis, 'Glaring Favoritism Shown Again to Harry Bridges', Los Angeles Times, May 8, 1938, p. A5; 'Miss Perkins Removal Asked', Los Angeles Times, June 23, 1938, p. 5.

302 Edward Sullivan to Robert Stripling, 'Report \#1', July 2, 1938, Box 11, Dies/NA.

${ }^{303}$ Edward Sullivan to Robert Stripling, 'Report \#2', July 3, 1938, Box 11, Dies/NA.
} 
Hynes and himself to travel up the Californian coast later in July, with the intention of meeting with anti-communist groups in those cities. In the meantime Sullivan met with the Los Angeles Mayor Frank Shaw, two chiefs of the LAPD, Margaret Kerr of the BAF, and A. A. Hopkins of the ONI and L.A. County Sheriff's office. By this point Sullivan was very pleased with the progress of his investigations in California, and the cooperation offered to him by everybody he had met, who he found eager to cooperate and be given a chance to put forward the information they had collected in a public forum. Buoyed by these successes, Sullivan speculated that 'what we expect to prove is the tiein between the millions of losses sustained by the Agricultural interests on this coast with radical activity and trace it through to the waterfront', where it could be pinned on Bridges. ${ }^{304}$

On July 17, 1938 Sullivan left Los Angeles, travelling by train with Captain Hynes to San Francisco, where a meeting was held the following day under the auspices of the American Legion. This meeting would determine much of the focus of the Dies Committee investigations in California. Also present at the meeting were Kendall Dazey of the Industrial Association of San Francisco, Walter Peterson of the Waterfront Employers Association, Harry Jung of the AVIF in Chicago, Harper Knowles of the Associated Farmers and American Legion, and Stanley Doyle, who claimed to be a 'special agent' of the state of Oregon. Sullivan's companions were sceptical of the committee at first, stating that any investigation would be fruitless 'unless the committee goes into the activities of Harry Bridges', who all present agreed was the key communist agitator on the West Coast. With Sullivan's assurances that the committee would indeed go after Bridges further meetings were planned, and Knowles was elected to serve as chairman with the final say on what evidence would be presented to the committee in service of their aim. ${ }^{305}$

Sullivan and Hynes then travelled up to Seattle via Portland, where he met with another name on his list-district immigration official Raphael Bonham, who had been working with Copeland earlier in the year. According to Sullivan, this meeting was 'off the record' due to longstanding conflict between Bonham and Secretary of Labor Frances Perkins. Despite this

\footnotetext{
${ }^{304}$ Edward Sullivan to Robert Stripling, 'Report \#9', July 8, 1938, Box 11, Dies/NA.

${ }^{305}$ Edward Sullivan, 'Report on trip to San Francisco, Portland and Seattle and return', July 27, 1938, Box 11, Dies/NA, pp. 1-2.
} 
caveat Sullivan recorded Bonham's statement that if the committee were willing to go 'all the way' with their investigation, 'enough evidence is now available that will create public demand so overwhelming for Bridges deportation that no one can prevent it'. Bonham suggested that somebody at the Department of Labor office in Washington was protecting Bridges, and if the committee compared the official file in Washington, D.C., with the one that Bonham had submitted, it would be easy to see if any evidence had been removed from Bridges' file. In Seattle Sullivan met a former CP member named J. R. Ferguson, who had been lined up as a witness against Bridges in the aborted deportation hearings. Ferguson's credibility had been vouched for by several unnamed American Legion leaders who Sullivan also met while in Seattle. ${ }^{306}$

Sullivan and Hynes returned to San Francisco on July 23. En route they stopped in Portland, where detectives tried to have the committee furnish funds for a junket to Los Angeles-in return for evidence which supposedly constituted an 'air tight case' against Bridges. More productive was a July 25 meeting in San Francisco with Harper Knowles and Stanley Doyle, at which Doyle claimed to have evidence proving official collusion with Bridges by Secretary Perkins to subvert the deportation proceedings. According to Doyle, 'the head of the immigration service in San Francisco called Harry Bridges [to his office], where this immigration man read to Bridges a confidential letter from the Secretary of Labor, telling Bridges to be careful of his conduct and not to arouse Senator Copeland too much' ${ }^{307}$ Sullivan and Hynes then met with representatives of all the groups they had met with on the $18^{\text {th }}$, who affirmed their commitment to gather evidence for the committee with Knowles as the group's official representative. ${ }^{308}$

Furnished with the collected surveillance information and cooperation of Californian experts Sullivan submitted his report just as the committee was about to begin its first hearings in Washington, D.C. An August 15 press release summarising Sullivan's research highlighted a number of Californian targets suspected of un-American activities. These included the Workers Alliance, the Anti-Nazi League of Hollywood, the North American committee to aid Spanish

\footnotetext{
306 Ibid.

307 Ibid.

308 Ibid.
} 
Democracy, agricultural unions in the Imperial Valley, leftist faculty in public universities, and the CIO. The report thanked Hynes for his aid to Sullivan and singled him out for praise, stating that 'the city of Los Angeles is indeed fortunate in having a well organised Intelligence Bureau within its police department under the direction of Captain William F. Hynes [...] whose wealth of information on the subject and [...] mass of evidence is without equal on the Pacific Coast' ${ }^{309}$ This praise came too late for Hynes, who was then embroiled in the scandal that would soon lead to the recall of Mayor Frank Shaw. By November Hynes had been demoted from his post and the LAPD Intelligence Bureau disbanded, the result of a citizens' anti-corruption investigation which had employed surveillance to collect information on corrupt 'Red Squad' officers and their bosses in the city government. ${ }^{310}$

The press responded favourably to the 'revelations' about Californian anti-American activities exposed in Sullivan's report. Sullivan's accusations of 'unbridled and unchecked Communistic activities' running 'rampant' within Hollywood were a particular focus of the Los Angeles Times, which also reported the public responses from groups that Sullivan had accused. ${ }^{311}$ A public battle began, with the Anti-Nazi League of Hollywood challenging Sullivan to produce evidence for his assertions, which, they argued to reporters, had been developed with the aid of Hynes and the recently disgraced and dissembled LAPD Intelligence Bureau. ${ }^{312}$ Sullivan's critics didn't know that the primary source for his assertions about communism in the film industry were in fact the anecdotal accounts provided by English actor Victor McLaglen. In fact, Sullivan didn't seem to have any documentary evidence at all when he made his accusations, and was instead relying on an agreement that the contacts he had made would supply evidence when the committee visited California. ${ }^{313}$ Studio Producer John Considine spoke on behalf of the industry when he said that 'the screen is beginning to get sick and tired of being the fall guy for every petty sensationalist who wants to get his name in the papers',

\footnotetext{
309 Press Release on Investigative Report of Edward Sullivan, August 14, 1938, Box 11, Dies/NA.

${ }^{310}$ The story of Clifford Clinton, CIVIC, and the investigation into the LAPD Intelligence Bureau is a fascinating one, and one I regret not having the scope to tell here. For further information begin with 'Two Hundred Officers Shifted in Shake-Up', Los Angeles Times, December 1, 1938, p. A1. The papers (and some investigative material) of Clifford Clinton are housed at UCLA Library Special Collections, and for the interested reader, are well worth consulting-The Clifford E. Clinton Papers, Young (Charles E.) Research Library, UCLA Special Collections, University of California, Los Angeles.

311 'Red Aid Linked to Film Stars', Los Angeles Times, August 15, 1938, p. A1; 'Van Dyke Adds to Film Defense', Los Angeles Times, August 19, 1938, p. 2.

312 'Anti-Nazi Leaguers Fight Red Aid Charge', Los Angeles Times, August 16, 1938, p. 6.

${ }^{313}$ Edward Sullivan to Robert Stripling, 'Report \#2', July 3, 1938, Box 11, Dies/NA.
} 
insisting that there was no basis to Sullivan's charges at all. ${ }^{314}$ Over the following weeks of testimony several of the committee's witnesses repeated Sullivan's accusations, supplying some of the evidence he lacked.

The main focus of Sullivan's report however was Bridges, who worked from his 'hotbed of communist agitation' in San Francisco. Speaking on behalf of the 'overwhelming majority' of business leaders in California, Sullivan asserted that Harry Bridges was personally responsible for 'over $60 \%$ ' of the industrial unrest on the Pacific Coast, had colluded in 'actual cases of murder and kidnapping', and was an active member of the Communist Party who had attended meetings of upper echelon CP officials. Sullivan's report claimed to have witnesses in place who could testify to these facts, and to the further charge that officials of the Department of Labor, instead of moving to deport Bridges as many business leaders wanted, had in fact protected Bridges and assured him of the Department's good intentions. ${ }^{315}$ Almost all of these sensational charges had been developed in cooperation with those present at the secret meeting in San Francisco on July 18, or in the further consultations that Sullivan had with members of the surveillance network.

The hearings began in Washington on August 12, 1938. Almost immediately the Dies Committee became a forum for attacks on the La Follette Civil Liberties Committee. On August 13 Dies and his colleagues heard from Daniel Frey of the AFL, which since 1935 had been working against attempts by the $\mathrm{CIO}$ to reorganise American labour into industrial unions as an alternative to the craft unions of the AFL. The CPUSA shared this goal with the CIO, leading conservative labour leaders like Frey to claim that the La Follette committee was also communistic by virtue of its support for the CIO. Frey submitted a host of membership details of Communists among the CIO leadership to substantiate the first connection, and alluded to 'numerous reports of close contacts between investigators for this [La Follette] committee and members of the Communist Party' to make the further link. ${ }^{316}$ This type of communist accusation had been the AFL's preferred way to contextualise the rivalry between itself and the

\footnotetext{
314 'Hollywood League Demands that 'Red' Charge be Proved', Los Angeles Times, August 18, 1938, p. 6.

315 'Federal Official Protects Bridges, Dies Aide Charges', New York Times, August 15, 1938, p. 1.

${ }^{316}$ Special Committee on Un-American Activities, 'Testimony of John P. Frey, President of the Metal Trades Department of the American Federation of Labor', Hearings to Investigate Un-American Propaganda Activities in the United States, Volume 1, (Washington, D.C: G.P.O., 1939), p. 106 [Hereafter referred to as Hearings on UnAmerican Propaganda].
} 
CIO since 1935. By enlarging this smear to include the Senate Civil Liberties Committee Frey sought to link his allies on the Dies Committee with traditional, respectable AFL labour, and the rival committee with the radical militancy of the $\mathrm{CIO}$ and communism.

Among the next group of witnesses was Margaret A. Kerr, the secretary-manager of the BAF, who had come to convey the group's collected surveillance on Bridges. Revealing that Bridges had been under investigation by the BAF for some time, Kerr offered the same information she had passed to Senator Copeland back in February on the alleged Communist Party membership of Harry Bridges. ${ }^{317}$ This included what she claimed was the Communist Party membership book of Bridges, obtained from one of the BAF's undercover informants in the CP named Irving Markheim. In his absence Markheim's affidavit was submitted into the record by Kerr, which was read aloud by Chairman Dies.

The affidavit details Markheim's recruitment by the BAF as a surveillance operative, as well as his activities as a spy within the Los Angeles Communist Party. Based on what he described as a 'very keen sense of patriotism', Markheim 'concluded that it was his duty as a loyal citizen... to inform himself by proper methods as to subversive activities and to place such information at the disposal of patriotic agencies'. ${ }^{318}$ Markheim approached the BAF in 1932 to offer his services, an offer that Kerr accepted, suggesting that Markheim join the party in order to obtain information from within. ${ }^{319}$ During his first years in the party, Markheim alleged that he had met Bridges on several occasions, both at official CP meetings and elsewhere, and had been introduced to Bridges both by his real name and by the name of Harry Dorgan. ${ }^{320}$ Presumably it was not until after the 1934 general strike in San Francisco that the significance of proving Bridges' CP membership became known to Markheim, after which point he must have begun the process of gathering evidence. Somehow, though he does not reveal how, Markheim obtained Dorgan/Bridges' CP membership book, which he then passed on to Margaret Kerr. Upon receiving this Kerr sent the information to Senator Copeland, whose responsibilities at that time included oversight of interstate transportation and the shipping industry as Chairman of the Senate Committee on Commerce. Kerr was thus asserting that Markheim's affidavits

\footnotetext{
317 'Testimony of Miss Margaret A. Kerr', Hearings on Un-American Propaganda, Volume 1, p. 713.

318 Ibid, pp. 718-20.

319 Ibid, p. 718.

${ }^{320}$ Ibid, pp. 718-19.
} 
were the heart of the 1938 deportation proceedings against Bridges, which sought to prove his CP membership based on Markheim's information.

A second affidavit submitted by Kerr records what allegedly happened next. During June of 1938, several months after his original affidavit had been sent to Senator Copeland, Markheim claimed that he began being subjected to anonymous threats and intimidation. ${ }^{321}$ These took the form of threatening phone calls from strangers who knew about the BAF affidavit, as well as an alleged hit-and-run by an automobile, followed by an anonymous threat that he would 'be sorry' he signed the BAF affidavit. ${ }^{322}$ Markheim also claimed to have been summoned by ACLU attorney Abraham Wirin to his office on July 18, 1938, where he found Communist literature scattered around the offices, casual talk of upcoming strikes among the staff, and Bridges himself in attendance. Despite repeated denials that he had signed any affidavit, Markheim claimed that Wirin subsequently offered him $\$ 500$ to leave town for Mexico, and to remain there until Wirin called him back. ${ }^{323}$ Wirin's response to these charges reversed the source of funding, claiming instead that Markheim had told him that Kerr had paid for a perjured affidavit, and now wanted money from Wirin to retrieve it. ${ }^{324}$ This would not be the last time that accusations of perjury accompanied affidavits asserting Bridges' $\mathrm{CP}$ membership.

When Kerr returned to the stand on Friday, August 19, 1938 her testimony was sought regarding the specifics of the material she had sent to Copeland, and which had in turn been passed on to the Department of Labor. During the course of Kerr's testimony the implication was brought out that somebody had advised Bridges about Markheim's affidavit against him, leading to the threats and attempted bribes that Markheim testified to having experienced in June. Concluding that 'there must have been a leak somewhere', committee member Noah Mason proposed three possible locations-the BAF, Copeland's Senate Committee on Commerce, or the Department of Labor. Neither Copeland nor the BAF were further pursued as possible sources of the leak. This is unsurprising given that two days earlier the Los Angeles Times had reported an announcement by the committee members to inquire into the

\footnotetext{
321 'Affidavit of Irving Norman Markheim', Hearings on Un-American Propaganda, Volume 1, pp. 763-65.

322 Ibid, p. 764.

323 Ibid, p. 765.

324 'Civil Liberties Attorney Denies Bridges Case Charges', Los Angeles Times, August 19, 1938, p. A2.
} 
Department of Labor's actions concerning Bridges. This investigation, reported the Times, included a request for all of the Department's files on Bridges to check for missing documents as Bonham had suggested to Sullivan in July. ${ }^{325}$ Dies and the other committee members had clearly already determined that any leak must have come from the Department of Labor, and would pursue it for as much political capital as possible.

Another way the committee hosted attacks on the New Deal and its public representatives was by establishing links between them and Communist front groups. On this topic the committee heard from Joseph Brown Matthews, who described himself as a former 'fellow traveller' who had since renounced his leftism. ${ }^{326}$ Matthews testified that he had been among the leadership of many Communist Party fronts, including the ILD, the National Student League, the Unemployed Councils, and the American League against War and Fascism. Matthews told the committee about the day-to-day work of infiltrating these organisations, and how the building of this 'United Front' was secretly directed by strategically placed CPUSA members to advance the aims of the Soviet Union. Thus communist-infiltrated pacifist groups, according to Matthews, only advocated peace in order to secure 'a breathing spell' during which 'the world revolution of the proletariat may be prepared'. ${ }^{327}$ Analogous too were the aims of the New Deal, argued Matthews, thanks to the sixty members of the U.S. congress that he asserted were either members of the American League for Peace and Democracy or had lent their support to communism aims. ${ }^{328}$

Matthews claimed that securing the public support of notable citizens was a key aim of the $\mathrm{CP}$ fronts he had been involved with. In this way public figures could be duped into lending their public support and considerable influence to organisations which harboured intentions unknown to their sponsors. Matthews named Eleanor Roosevelt among the naïve victims of this public manipulation-pointing to her support of the World Youth Congress then meeting in New York, which he stated was dominated by communist delegates. Other 'suckers' included

\footnotetext{
325 'Bridges Deportation Case Will Be Checked', Los Angeles Times, August 17, 1938, p. A8.

${ }^{326}$ Matthews was himself the former object of the surveillance network's attention, attracting the notice of Van Deman for his activities as a CP front group spokesperson. See, for example-'Largest U.S. Pacifist Group Splits; J. B. Matthews Ousted', Daily Worker, c. December 1933, R-207, Box 2, RHVD/NA.

327 'Testimony of J. B. Matthews', Hearings on Un-American Propaganda, Volume 1, p. 868-928.

328 'Reds Exploiting of Officials Told', Los Angeles Times, August 21, 1938, p. 1; 'Six Stars Listed as Aiding Reds', Los Angeles Times, August 23, 1938, p. 1.
} 
major Hollywood stars such as Clark Gable, Robert Taylor, James Cagney, and even nine year old actress Shirley Temple, all of whom Matthews stated had allowed their names to be used by CP fronts, effectively becoming vehicles for communist propaganda. ${ }^{329}$ Matthews' claims generated a sensation in the press, leading the Times to conclude that, aside from Mickey Mouse and Snow White, 'almost everyone in Hollywood has been signed up to some Communist front organization' ${ }^{330}$

Kerr returned to the stand for her final day of testimony on August 22, 1938. In this phase she expanded on her earlier statements about the extent and nature of communist front activities in Los Angeles. Kerr spoke at length about the connections between the Communist Party and various fronts in Los Angeles, specifically naming the American League for Peace and Democracy, the Friends of the Abraham Lincoln Brigade, the United Youth Committee to aid Spanish Democracy, the Motion Picture Artists' Committee, and the Medical Bureau to Aid Spanish Democracy as groups acting under communist influence. Like Matthews, Kerr testified that the film industry was similarly infected by communistic ideology, but characterised their involvement differently-rather than describing the exploitation of naïve thespians Kerr claimed to have proof of active and widespread support for communist causes. Some of this information she collected personally, such as at a meeting she attended in Los Angeles commemorating the twentieth anniversary of the Bolshevik revolution, where Kerr stated $\$ 1000$ was raised for a media campaign by a CP section within the film industry. ${ }^{331}$

Kerr's testimony about communist fronts was the last in that stage of the Washington hearings of the Dies Committee. An article in the Washington Post on August 24 announced the committee's intention to hold hearings in California to hear further testimony on CP activities in Hollywood, but a lack of funds would prevent that goal from being realised in the immediate future. 332

\footnotetext{
329 Ibid; 'Testimony of J. B. Matthews', Hearings on Un-American Propaganda, Volume 1, p. 868-928.

330 'Six Stars Listed as Aiding Reds', Los Angeles Times, August 23, 1938, p. A1.

331 'Testimony of Miss Margaret A. Kerr', Hearings on Un-American Propaganda, Volume 1, pp. 767-771, 973-977

332 'Alien Inquiry Begins a Junket to Hollywood, Beery Bunds', Washington Post, August 24, 1938, p, 1.
} 


\section{Suspicious Eyes and Expanding Targets}

Some of the research efforts that made up Kerr's testimony are preserved in Van Deman's archive. During 1937-1938 the BAF and Van Deman had shared a lot of information on CP fronts, and were particularly interested in US citizens supporting the loyalists in the Spanish Civil War. ${ }^{333}$ Another major target of the surveillance was the Hollywood Anti-Nazi League, which had attracted a great deal of negative innuendo from the committee members during the hearings. This negative attention had precipitated public disavowals of communist sympathy from members of Hollywood's film industry, while the Anti-Nazi League itself characterised its activities not as an expression of support for communism, but instead as a stand against fascism in Europe and the United States. 334

Some of the reports detailing the political beliefs of suspected Hollywood subversives suggest a particularly intrusive and cynical level of suspicion. B-11's surveillance reports in February 1938 recorded the activities of several pro-loyalist organisations with significant support among film workers. One entry named Edward Arnold, Richard Arlen, Lewis Milestone, Florence Eldridge, Sylvia Sidney, Paul Muni, Franchot Tone, and Melvyn Douglas as supporters of a charity which was fundraising to send 'several shiploads of boys, bandages and clothing to the innocent victims of the Spanish war' ${ }^{335}$ Another entry in the report detailed a campaign by Hollywood actors to encourage children in the U.S. to send Christmas gifts to the children of loyalist Spain. B-11 also viewed with suspicion a number of actors who had agreed to provide entertainment at a benefit to purchase medical ambulances and ship them to the front lines. ${ }^{336}$ The fact that Edward G. Robinson attended a party at Oscar Hammerstein's house is recorded, an event at which wealthy Hollywood children contributed gifts to donate to Spanish children. Of the many individuals named most are connected in some way with support for Loyalist Spain, yet there is no evidence of actual Communist Party membership reported, or even seemingly investigated.

\footnotetext{
${ }^{333}$ For examples, see this collection of published pamphlets of pro-loyalist groups, sent to Van Deman in February 1938-R-1879, R-1880, R-1881, R-1883, R-1884a, R-1884b, R-1884c, R-1885a, Box 14, RHVD/NA.

334 'Hollywood League Demands that 'Red' Charge be Proved', Los Angeles Times, August 18, 1938, p. 6; “Anti-Nazi Leaguers Fight Red Aid Charge", Los Angeles Times, August 16, 1938, p. 6.

${ }^{335}$ Report on radical activities in Hollywood, February 18, 1938, R-2767b, Box 21, RHVD/NA.

336 Ibid.
} 
The attention paid to the Californian film industry by both the Dies committee and members of the surveillance network was the product of an overall increase in leftist activity as film industry personnel became involved with causes or organisations with CP links. Moreover, the Communist Party's opposition to Fascism and Nazism in Europe undoubtedly attracted members of an industry which included Jews in significant numbers. Both factors reflected the success of the $\mathrm{CP}^{\prime}$ s popular front strategy, which sought to encourage contacts (and ultimately membership) through exactly these sorts of liberal causes. The success of this strategy must have attracted attention to the industry's political allegiances however, especially when coupled with the awareness of film as a valuable propaganda weapon. As a result, the widened scope for surveillance and suspicion also expanded the workload and pay for the professional contributors to the surveillance network, regardless of the actual number of $\mathrm{CP}$ members in Hollywood.

Chart 3.1: Van Deman Industrial Targets, 1932-1933, 1935, 1937

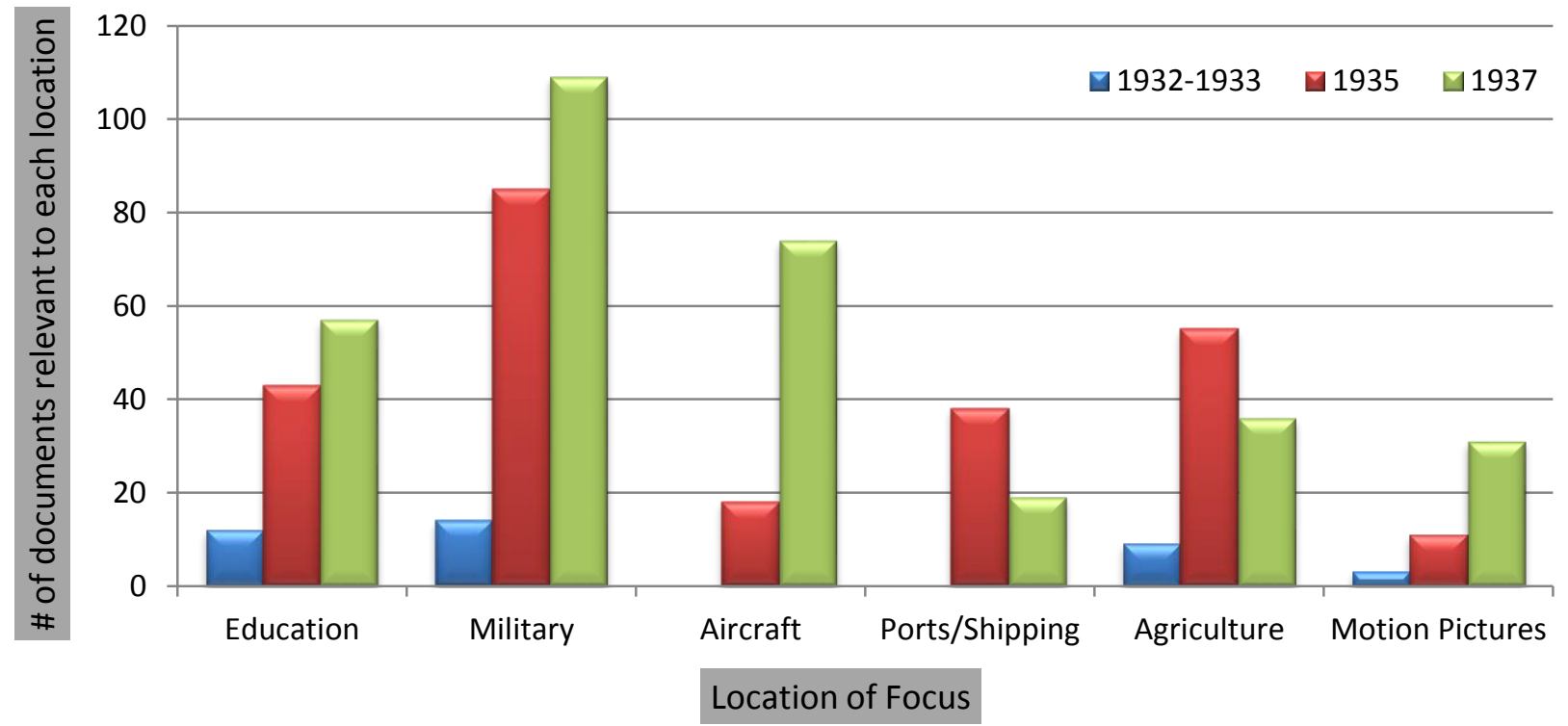

Chart 3.1 demonstrates the attention paid by documents in Van Deman's archive to various industries or institutions between 1932-33, 1935, and 1937. This attention can be thought of as the archival manifestation of the surveillers' gaze-highlighting the locations that Van Deman's contributors felt to be most worthy of surveillance. As the final group of columns show, suspected subversive activities in the film industry were a minor interest in the first years of the archive's existence, only generating three documents. This increased to eleven in 1935the same year the Communist International urged party activists to broaden their efforts within 
a wide range of social and political organisations. By 1937 the number had climbed to thirtyone, still a relatively minor concern compared to the surveillance network's vigil over education, agriculture, the military and aircraft manufacturing, but one that had overtaken the shipping industry in terms of the frequency of surveillance, perhaps counterintuitive given the attention the network placed on the pursuit of Harry Bridges. ${ }^{337}$

The industrial location that was subject to the largest increase in surveillance by contributors to Van Deman's archive in 1937 was not investigated by the Dies committee in its first round of hearings. ${ }^{338}$ This was the aircraft industry, which held a large number of military contracts undoubtedly of concern to the former General, which brought aircraft manufacturing within his defensive vigil over the military. Between 1932 and 1937, the period described in Chart 3.1, there was a massive increase in surveillance. In 1932 and 1933, not a single document in Van Deman's archive records an interest in communist efforts in this field. A modest rise occurred in 1935, with eighteen documents focused on aircraft factories, mostly concerning unionisation among workers at the Douglas aircraft factory based in Santa Monica. By 1937 surveillance of the aircraft industry had increased substantially, with seventy-four documents preserved in the archive. This dramatic increase was undoubtedly partly due to the growth of the industry, as more and more companies moved manufacturing from the East to take advantage of California's favourable (to employers) labour conditions. This attracted the attention of the $\mathrm{CIO}$, which responded by directing significant effort to establish a foothold in the Californian factories.

Documents in Van Deman's archive record the unionisation of the industry through the reports of undercover informants working within several of the major Californian factories. The organising campaign was conducted first under the auspices of the Western Mechanics' Industrial Union [WMIU], joined later by the United Auto Workers of America [UAW], which had sponsored the MWIU's entry into the CIO. ${ }^{339}$ According to the author of a February 1937

\footnotetext{
337 The explanation for this is actually rather simple-after 1935 the network targeted Bridges directly, placing all their emphasis on securing information that would aid in his deportation rather than maintaining scrutiny over the industry as a whole.

${ }^{338}$ The aircraft industry was covered in Un-American Activities Committee hearings at the end of 1940, probably as a result of the war in Europe focusing attention on the potential for sabotage.

339 The UAW was a CIO union that at the beginning of 1937 had assumed leadership of a sit-down strike among General Motors employees at Flint, Michigan. That strike was ultimately a major victory, establishing the UAW as
} 
report on the Douglas aircraft plant in Santa Monica, the industry was highly vulnerable to communist infiltration. This was particularly true in the Douglas plants, where low wages and the worst union-busting practices in the industry had facilitated widespread discontent. The militant atmosphere led Van Deman's agent to warn that although the 'vast majority of the employees are not in sympathy with communism nor even with near Communistic ideas', 'they might be in sympathy of a general strike to better their wages and their working conditions.' From there, the agent made a significant leap, arguing that 'mob psychology at that time could easily take them into an actual armed uprising against the government' ${ }^{340}$ These echoes of San Francisco in 1934 must have resonated strongly with Van Deman, because in the weeks afterwards Van Deman began receiving reports from agents embedded within other aircraft manufacturers in Southern California, including at the Northrop, Consolidated, and Lockheed factories.

According to Van Deman's agents, there were other concerns beyond armed insurrection by industrial workers. Sometime in March 1937 Van Deman received a comprehensive report on the links between the Los Angeles CP and the WMIU, covering all of the separate factories and companies then in Southern California. Suspicion centred on Andrew Schmoulder, the 'organizer and leading spirit' of the WMIU, and a former communist who had been excommunicated from the party after securing organisational assistance and a charter from the CIO. ${ }^{341}$ Though the report stated that as a result the WMIU was 'no longer a Communistaffiliated union', its 'leadership is strongly Communistic' nevertheless. ${ }^{342}$ Since the WMIU was the dominant union in the industry in Southern California, this was of major concern to Van Deman and the report's author, who doubted the CP's announcements that it 'does not sanction sabotage or individual violence'. Reminding Van Deman of the reason for such scepticism, the agent reported CP discussion of 'a way of putting some sort of acid into a portion of the wing supports that would not act for a considerable period after it had been so placed', but when

the recognised representative of GM employees and furthering the CIO's challenge to the AFL as an alternative voice for American labour. Their efforts in the California aircraft industry did not bear fruit until 1941, outside the scope of this thesis.

340 'Radical Activities re: Aircraft industry. Douglas Aircraft', February 18, 1937, R-1868, Box 14, RHVD/NA.

${ }^{341}$ At that time the party line was for union CP organisers to secure AFL charters and work within craft unions. Schmoulder's commitment was to industrial unionism in the short term, which preceded the CP's later support of the $\mathrm{ClO}$.

${ }^{342}$ Report on organizational activities in the aircraft industry, c. March 1937, R-1894, Box 14, RHVD/NA. 
under stress would cause the wing to detach from the fuselage of the aircraft. ${ }^{343}$ This kind of report must have enraged Van Deman, confirming his fear of CP sabotage of military technology, while demonstrating how the organisation of workers into labour unions could in his mind be conflated with CP-led sabotage and treason.

Beyond sabotage, Van Deman and his agent also feared the potential for a well-organised and $\mathrm{CP}$ directed stoppage of the Californian war industries. According to one of his agents, Los Angeles County CP Organiser John Leech had repeatedly stressed the importance of the industry at party meetings. To the $\mathrm{CP}$, this importance supposedly stemmed from California's position as a 'center for the production of supplies vitally necessary in war such as oil and gasoline and particularly the manufacture of airplanes'. ${ }^{344}$ Once properly organised, California's workers would thus have the ability to halt the production of these supplies in the event of any war unpalatable to $\mathrm{CP}$ leadership.

Reports such as these make clear the nature of the concern felt by Van Deman and the undercover informants he had placed in the aircraft industry. These fears seem ideally suited to the psychology of a career military man-armed insurrection, such as Van Deman had battled against in the Philippines, the sabotage of military equipment, and the outright surrender of the industry of war to the whims of a radical minority who might choose pacifism when it suited their own aims.

\section{Strengthening the Conservative Bloc}

The first round of hearings held by the Dies committee in August 1938 had been a success. They had generating headlines, testimony, and the opportunity for surveillance organisations to expose their opponents' activities before a panel of sympathetic legislators. Washington hearings of the un-American activities committee continued in earnest through to the end of November 1938, as witnesses continued to agitate for Bridges' deportation, while hosting

\footnotetext{
343 Ibid.

${ }^{344}$ Report on organizational activities in the aircraft industry, c. March 1937, R-1894, Box 14, RHVD/NA.
} 
further assaults on the New Deal, the CIO, and the various liberal groups they claimed were fronts for the CPUSA.

One of the key witnesses in this phase was Harper Knowles, who was in Washington as the representative of the American Legion's radical research committee. Though he didn't say so at the time, he was also there as the representative of the anti-Bridges coalition who had met with Sullivan in July. This was the culmination of several years' work for Knowles and his allies-an opportunity to expose Bridges and other California CP members before a sympathetic government committee with the ability to generate both political momentum and public support for Bridges' deportation. Thus it is perhaps puzzling that when granted this opportunity Knowles and his counsel Ray Nimmo chose instead to delay presenting their full case until the committee held hearings on the West Coast. Part of the justification they gave for withholding their case was out of concern for the safety of government witnesses against Bridges. This claim rested on the implication that $\mathrm{CP}$ or union members might commit violence to silence the witnesses, an effective claim itself in terms of its public relations value. ${ }^{345}$

Instead, Knowles and Nimmo offered wide-ranging, extensive testimony backed by exhibits that purported to link a huge variety of Californian organisations and institutions to the Communist Party and ultimately to Bridges himself. Organisations described as 'radical in their activity' included the Inter-Professional Association, the Western Writers' Congress, the Simon J. Lubin Society, the American Friends of the Soviet Union, and the North American Committee to Aid Spanish Democracy - all of which had been infiltrated by operatives of the surveillance network. Institutions attacked included the 'pink educators' at the University of California, Berkeley, from which nine academic faculty 'interested in the left wing movement' were publically named. ${ }^{346}$ Employing much of the same rhetoric as the BAF had previously done before the Fish committee in 1930, Knowles' attacks on educators and 'soft left' organisations similarly sought to proscribe a permitted ideological spectrum in California, beyond the bounds of which the stamp of communist taint could be applied.

Claiming that these were just a few of the myriad forums permeated by $\mathrm{CP}$ members, Knowles and Nimmo also used the public platform to smear Democratic Party candidates and

\footnotetext{
345 Hearings on Un-American Propaganda, Volume 3, pp. 1483-85

346 'Witness Tells of Reds' Plot to Tie Up California Foodstuffs', Los Angeles Times, October 26, 1939, p. 1.
} 
Roosevelt administration officials with allegations of red affiliation. Knowles was joined by fellow legionnaire and former undercover CP informant Joseph Hannon in these attacks, which concentrated on Secretary Perkins, Democratic candidate for U.S. Senate Sheridan Downey, and Democratic candidate for California Governor Culbert Olson. Hannon claimed that these individuals were 'affiliates and members of Communist Party organizations who follow [...] the party's lines laid down by the Communist Internationale', and were funded and supported politically by a coalition of radical leftists which included Harry Bridges. ${ }^{347}$ With U.S. Congressional and California gubernatorial elections mere weeks away, Olson responded by calling Knowles a 'madman', and was joined by President Roosevelt and the other smeared candidates in decrying the use of the committee for what they viewed as plainly partisan political objectives, phrased as accusations in lieu of any substantive evidence. ${ }^{348}$

During the second round of hearings attacks on the Senate Civil Liberties Committee became more explicit, with the Dies committee providing a vehicle for several extremely hostile witnesses to air their grievances. One of the more extreme accusations was made before the committee by William Gernaey, who had spent seven years undercover in the Communist Party on behalf of an unnamed industrial employer. According to Gernaey's testimony his employment ended in early 1937 when two La Follette investigators provided party members with expense vouchers linking him to his corporate employers, vouchers which he claimed could only have been obtained through illegal tampering with the postal service. After being confronted with this evidence Gernaey was expelled from the party, and immediately served with a subpoena to testify before the Civil Liberties committee. Gernaey alleged the investigators then informed their $\mathrm{CP}$ 'comrades' that since Gernaey was 'of no more use to the capitalist class' he 'will probably be killed within the next 24 hours', and that the CP members should all keep a careful record of their movements so they could prepare alibis. ${ }^{349}$ This testimony came mere inches short of accusing La Follette investigators of encouraging the murder of Gernaey, and of instructing CP members on how they might do it themselves without repercussion.

\footnotetext{
347 'Red Ties Laid to Downey and Olson', Los Angeles Times, October 27, 1938, p. 1.

348 'Downey Challenges Knowles After Calling Him Madman', Los Angeles Times, October 27, 1938, p. 2; 'Dies Defies Roosevelt in Reply to Attack', Los Angeles Times, October 27, 1938, p. 2.

${ }^{349}$ Hearings on Un-American Propaganda, Volume 2, pp. 1483-85; 'Red Foe Hits Senate Aides', Los Angeles Times, October 19, 1938, p. 3.
} 
Testimony such as this reinforced the strategic approach taken by Dies committee staff in the first hearings, which encouraged the public to perceive ideological links between the CPUSA, the La Follette investigation, and their political allies. This was aided by un-American committee members themselves, often through public innuendo about a secretive agenda underlying the La Follette committee's work. For example, committee member Harold Mosier he had information 'the people should know' about 'outspoken and known Communists' being present at the inception of the La Follette committee. In the aftermath of his vague assertion committee members announced to the media that they had voted to take the unprecedented step of investigating their rival committee directly. Some of the 'outspoken and known communists' were claimed to be members of the ACLU, the WILPF, and the CIO, while Senator La Follette himself was classified as belonging to a group of 'other liberals and socially minded people' ${ }^{350}$ Since Mosier admitted to the media that there was no evidence that any of the named individuals were actually $\mathrm{CP}$ members, the repeated association of these groups with the CPUSA was clearly the intended purpose of the announcement.

The left had to respond to these escalating and usually unsubstantiated attacks. One way to do so was by attacking the often weak credibility of government witnesses, or sometimes even the individuals that Dies and his colleagues had hired to collect information on their behalf. In late August 1938 a CIO organisation called Labor's Non-Partisan League sent the Dies committee office in Washington a series of documents alleging serious misconduct by their investigator Edward Sullivan. One affidavit alleged that Sullivan had attempted to pay for manipulated testimony from an incredulous witness. According to the affidavit's author, Walter E. Gordon, the attempted payoff had occurred after Sullivan had informed Gordon that the union he belonged to was run by 'Jew-Communists', and subsidized by CPUSA funds. Despite Gordon's disbelief, Sullivan allegedly made a crude promise of payment if Gordon would sign an affidavit affirming these statements. ${ }^{351}$ The variety of charges in the dossier detailed allegations from the period both before and during his employment as an investigator for the committee.

\footnotetext{
350 'Dies Group to Probe La Follette's Inquiry', Los Angeles Times, November 16, 1938, p. 18; 'Dies Attacks Roosevelt', Los Angeles Times, November 1, 1938, p. 1.

${ }^{351}$ Affidavit of Walter E. Gordon, August 19, 1938, Box 11, Dies/NA.
} 
Other documents collected by the League's investigators provided details of a series of anti-Semitic speeches and writings linking Sullivan to several U.S. fascists and organisations with violent intentions. One of these was James True, who Sullivan allegedly helped to publish an anti-Semitic, anti-Communist publication known as the Industrial Control Reports. ${ }^{352}$ Another copy of this report on Sullivan was sent to the chairman of the Rules Committee of the House of Representatives, who was responsible for the apportionment of funding to House committees. ${ }^{353}$ This represented a direct threat to the un-American activities committee's funding. Sullivan was dismissed from his investigative job shortly after the League's report was first sent, perhaps because of the negative publicity that he was attracting to the committee, or perhaps due to the committee's dwindling funds, which was the official reason given to Sullivan. ${ }^{354}$ This episode demonstrates that sections of the left employed the tactics of their opponents when it suited them.

As soon as hearings had begun in August Dies had issued complaints about the committee's lack of funds. This dearth of resources, he had announced, would prevent the committee from investigating the un-American activities revealed during Sullivan's investigation of California. ${ }^{355}$ These complaints continued through until the end of 1938, escalating over that time to posit a conspiracy against his investigations involving President Roosevelt, Eleanor Roosevelt, Secretary Perkins, and others, who he claimed continued to disrupt his efforts to secure the funding the committee needed to hold hearings in California. According to the Times, Roosevelt had asked Democrats in congress to block the un-American activities committee's funding. When told it was not possible because of popular support for

\footnotetext{
352 E. L. Oliver, 'Subversive Activities of Edward Francis Sullivan', August 26, 1938, Box 11, Dies/NA. It is worth mentioning, though likely a coincidence of interests that Van Deman received copies of Industrial Control Reports starting in 1935, during the period when Sullivan allegedly worked for True. It is highly likely that they knew each other, though there is no record of Sullivan meeting Van Deman while he was in California.

${ }^{353}$ E. L. Oliver to Adolph Sabath, January 26, 1939, Box 11, Dies/NA.

${ }^{354}$ Sullivan's misconduct continued after his dismissal. For example, in 1940 Sullivan was arrested and charged with impersonating a federal agent after representing himself as a special investigator for the Dies committee under loan by the FBI. While under this guise Sullivan had attempted to sell his services as an anti-strike consultant to the Pennsylvania railroad. For further information, see Elliot W. Finkel to U.S. Attorney-General, March 13, 1940, Box 11, Dies/NA.

355 'Hollywood Celebrities Linked with Communism in Report', Boston Daily Globe, August 15, 1938, p. 1.
} 
Dies, Roosevelt instead suggested the La Follette committee investigation be provided with additional funds in order to 'blanket' the opposition. 356

At the beginning of November the Los Angeles Times reported an announcement by La Follette Civil Liberties committee secretary Robert Wohlforth that investigators in San Francisco had already uncovered extensive evidence of labour violations. So far the committee's investigations had focused on Californian agricultural labour, and on the anti-labour employers' associations which had bankrolled strikebreaking activities in the San Joaquin and Imperial Valleys. The Associated Farmers of California came in for particular criticism, the president of which Wohlforth referred to as a 'kind of downtown vigilante, say a white-collar farmer', whose real loyalty was to the banks and corporations that were the dominant landowners in Californian agriculture. ${ }^{357}$ Wohlforth also announced that the committee was about to open an office in Los Angeles, where the enquiry would soon relocate to begin investigating Los Angeles' own employer associations and business front groups. Committee investigators were optimistic that they would soon have a chance to hold hearings and expose the evidence they had assembled on California's anti-labour organisations. These hopes were dashed when the November elections signalled a major national swing to the Republican Party, stifling any chance of securing new appropriations for a controversial and long-running enquiry.

Unbeknownst to the La Follette staff a spy was in their midst, who had been sending undercover reports on the investigators to Knowles at the American Legion. ${ }^{358}$ Over the winter months of 1938-39 this informant sent regular reports on the internal mood, personnel, and activities of the staff, including details such as Bridges' provision of staff with liquor to celebrate the successful serving of subpoenas on Knowles and Associated Farmers vigilante General Henry Sanborn..$^{359}$ This informant repeatedly asserted that many of the staff were CP members,

\footnotetext{
356 'President Seeks to Block Dies', Los Angeles Times, January 6, 1939, p. 9.

357 'Senate Group to Send Envoy', Los Angeles Times, October 28, 1938, p. 6; 'Civil Liberties Inquiry Slated', Los Angeles Times, November 1, 1938, p. 8.

${ }^{358}$ Report from undercover informant on La Follette committee investigative staff, c. November 1938, Box 1, Folder 7, CSC/SFSU. This informant's name may have been 'Frances W. Luler' as indicated by a notation written in pencil at the top of the first report. The name Frances also appears elsewhere as an agent of Knowles working with Henry Sanborn-see footnote 279, Chapter 2.

${ }^{359}$ Report from undercover informant on La Follette committee investigative staff, c. November 1938, Box 1 , Folder 7, CSC/SFSU.
} 
and beyond their labour investigations had an additional goal to 'prove that the Dies Committee evidence is practically all evidence collected by big business and thus proving that the Dies Committee is an employer organization'. ${ }^{360}$

Further reports and copies of staff correspondence sent by the informant detailed the material that the staff had so far collected, and how they were putting together that information. One piece of internal correspondence suggests the progress La Follette investigators had made to connect the various parts of the surveillance network, noting that it is clear that the associated farmers got some of their reports from Red Hynes of Los Angeles, San Francisco Police Department; the Industrial Association and Harper Knowles when he was head of the Subversive Activities Committee of the American Legion and from various California police departments when strikers or pickets were arrested. There are instances that from some of the cards information was apparently secured from somebody in the War Department'. ${ }^{361}$ It is highly likely that this last reference was to Van Deman, as he was regularly exchanging information with the Associated Farmers, and was probably the AFC's best conduit for accessing high-level confidential military files.

As detailed by Knowles' informant, the La Follette committee's funds were also rapidly running out, and the investigation slowly ground to a halt, delaying the California hearings initially scheduled for January 1939. While the committee was paralysed by a Senate which was reportedly 'not inclined to set aside another cent' for the investigation, some of the groups it had publically targeted went on the offensive, questioning the motives of La Follette and his colleagues while praising the work of Dies' own investigative committee. ${ }^{362}$ Recognising the possibility that only one of the duelling committees might receive continued funding, Senator La Follette instructed staff that 'the line of strategy to be followed at present is to attempt to prevent any appropriation of funds to the Dies committee'. If the current negative political

\footnotetext{
360 Ibid.

${ }^{361}$ Copy of letter from anon. to Robert Wohlforth, January 4, 1939, Box 1, CSC/SFSU.

362 'President Seeks to Block Dies', Los Angeles Times, January 6, 1939, p. 9; 'Red Enquiry Gets Backing', Los Angeles Times, January 19, 1939, p. A6; 'Liberties Group Asked to Investigate Union Chiefs', Los Angeles Times, January 7, 1939, p. 7.
} 
environment precipitated by the rightwards swing in the elections was passed, La Follette and his legislative allies might then begin in earnest a new fundraising campaign of their own. ${ }^{363}$

It seemed that the California phase of the civil liberties investigation was at risk of stalling before it had even held any hearings, despite the urging of Governor Olson and other reformists for the committee to receive the funding it needed. ${ }^{364}$ In the interim Knowles' informant reported the winding down of the San Francisco office, all the assembled research material being packed into shipping containers to be sent elsewhere. In these final days, the reports sent to Knowles mentioned the committee's contact with several notable California civil libertarians including Carey McWilliams, then a lawyer for the NLRB, who was working on his expose of Californian agricultural labour entitled Factories in the Field. ${ }^{365}$ Labour attorneys Richard Gladstein and Aubrey Grossman were also reported to be within the committee's orbit. For at least the last year their firm had been conducting its own research in preparation for the role of defence counsel in the deportation hearing of Harry Bridges. ${ }^{366}$ It is likely that McWilliams, Gladstein and Grossman all received some level of access to these files during this frantic period in the life of the Civil Liberties committee.

While La Follette worked on securing further funding for the committee the California NLRB took over investigative responsibilities at its own expense, assigning attorney David Sokol to continue research on the committee's behalf. ${ }^{367}$ One of the problems the NLRB had faced when attempting to enforce the Wagner Act in California was the exclusion of agricultural workers from its provisions. This left the agency without the mandate to intervene in agricultural labour disputes, despite the clear and widespread Wagner Act violations that it encountered. In response the NLRB developed a legal strategy which argued that some of the larger agricultural concerns in California were in fact 'industrial interests' because of either scale or composition. If successful, this would bring farm workers under Wagner Act provisions

\footnotetext{
${ }^{363}$ Report from undercover informant on La Follette committee investigative staff, January 5, 1939, Box 1, CSC/SFSU.

364 'Olson Urges Funds to Push La Follette Inquiry on Coast', Los Angeles Times, May 4, 1939, p. 8.

${ }^{365}$ Report from undercover informant on La Follette committee investigative staff, February 5, 1939, Box 1, $\mathrm{CSC} / \mathrm{SFSU}$.

${ }^{366}$ Report from undercover informant on La Follette committee investigative staff, February 3, 1939, Box 1, CSC/SFSU.

367 Sokol was with A L Wirin in January 1934 when attacked by Legion vigilantes in the Imperial Valley. See Hearings on Violations of Free Speech \& the Rights of Labor, Part 64, pp. 23645-46.
} 
and give the NLRB the mandate to enforce compliance. This strategy was an effective challenge to groups like the Associated Farmers, which represented many growers who also had investments in transport or shipping and other industries. As a result, NLRB field investigators sometimes found themselves the subject of concerted efforts to disrupt their research efforts whenever they showed up in California's farming regions. ${ }^{368}$

These legal skirmishes had produced a lot of negative publicity for the NLRB in California, as did the attacks on the agency before the Dies committee. The La Follette committee hearings offered the NLRB the hope for a reprieve through the public exposure of widespread anti-labour interference within the Californian agricultural industry. These revelations would justify the NLRB's attempts to pursue the same groups under the legal auspices of the Wagner Act. Long term, the Senate Civil Liberties Committee might also possibly bring about a political situation through a strengthening of the Wagner Act. The close cooperation enjoyed between the NLRB and the La Follette committee is thus unsurprising, and similar in its mutual benefit to the relationships enjoyed between the Dies committee and its own allies.

Equally unsurprising was the resistance that Sokol encountered after taking over the La Follette investigation in Los Angeles. This resistance emerged from law enforcement whose records had been subpoenaed by the committee, beginning with the Los Angeles County Sheriff's office refusing Sokol access to its records in February 1939. Reminding their readers that Sokol had 'on numerous occasions represented radicals' in the city's courts, the Times reprinted the legal advice the Sheriff had received against complying with the subpoena, including the fact that he had 'no assurance that this investigator possesses authority to keep the information confidential' ${ }^{369}$ Without such an assurance, the clear implication was that allowing access might therefore endanger any confidential sources the Sheriff had employed in pursuit of persons 'under surveillance for possible interest or engagement in subversive activities'. In March the LAPD took the same position, ejecting Sokol from the offices in police headquarters that Bowron had ordered to be provided for him, and denying him any further

\footnotetext{
${ }^{368}$ For accounts of one battle between the Associated Farmers and the NLRB in the Imperial Valley, see-'Labor Fight Move Balked', Los Angeles Times, February 18, 1939, p. 9; 'Valley Labor Case Warms', Los Angeles Times, February 19, 1939, p. 11; 'Labor Board Aide Accused', Los Angeles Times, February 21, 1939, p. 10.

369 'La Follette Group Balked', Los Angeles Times, February 4, 1939, p. A1.
} 
access to their files. ${ }^{370}$ Clearly, the La Follette committee and the NLRB were threats to the LAPD whose investigations should be impeded whenever possible.

This implication that La Follette investigators might reveal the identity of confidential sources to the radicals they had been tasked to spy upon was an echo of the testimony revealed a few months earlier before the Dies committee. Subsequent events show that these fears were at least partly justified, as became apparent during the deportation hearing of Harry Bridges, which finally began in July 1939. This hearing represented another skirmish between the two duelling committees, and provided a major target of the surveillance network with an opportunity to expose the activities of key elements of the opposition to the CIO and Bridges' activities as a labour leader.

\section{The Defence of Harry Bridges}

Harry Bridges' deportation hearing began on July 10, and began with attorneys from Department of Labor establishing the foundation of their case - that Bridges was a CP member who had advocated the overthrow by force and violence of the government of the United States'. ${ }^{371}$ This argument was based almost entirely on the testimony of informants, many of whom were directly involved with members of the secret meeting with Sullivan in July the previous year. Some of them had already testified at least once before the Dies committee, and would repeat or embellish their charges again before the trial judge. The campaign to 'get' Bridges had finally been granted an opportunity to present evidence before a court with the power to deport. Clearly thrilled by the possibility of Bridges' forced departure, the Los Angeles Times credited the Dies committee with restoring momentum to the anti-Bridges campaign, while denouncing Secretary Perkins for the 'personal friendship' she reportedly enjoyed with Bridges. ${ }^{372}$ Underpinning the Times editorial was the belief, shared by California's surveillance

\footnotetext{
370 'Police Files Plea Rejected', Los Angeles Times, March 24, 1939, p. A3.

371 'Bridges Branded Red at Deportation Trial', Los Angeles Times, July 11, 1939, p. 1.

372 'The Bridges Hearing', Los Angeles Times, July 10, 1939, p. A4.
} 
network, that if Bridges could be deported to Australia as an alien radical it would mean the end of the political allegiance between New Deal Democrats and organised labour.

This promise was short lived however, as Bridges' legal team proved to have the resources and information to mount an effective defence. As the government's case unfolded, Gladstein and Grossman took every opportunity to impugn the credibility of the government's witnesses. First to take the stand was Laurence Milner, who claimed to have spent 5 years undercover as a communist on the orders of the Oregon National Guard. Milner testified that during this time he had personally observed Bridges paying party dues, making antigovernment remarks, and sitting in on $\mathrm{CP}$ marine 'fraction' meetings which 'could only have been attended by those high in the confidence of the Communist Party ${ }^{\prime 373}$ However, during cross examination Milner was forced to admit that he had perjured himself during earlier testimony as a witness in a criminal syndicalism case in Portland. When challenged on this he had at first denied the accusation, thus perjuring himself in the present hearing as well. As a result, his testimony was effectively rendered unreliable to everybody except the Times. Most importantly, this included presiding Judge John Landis, who referred Milner's perjured testimony to Labor Department lawyers to consider criminal charges. ${ }^{374}$

John Leech, the next government witness, fared little better. His own testimony was undermined from the start by two separate and contradictory affidavits he had signed regarding his knowledge of Bridges' alleged CP membership. When called by the government to testify, Leech claimed that he had signed the second affidavit absolving Bridges of any CP affiliation while under duress, threatened by CP thugs who had 'tried to force their way into the [family] house' ${ }^{375}$ His wife Mary Leech corroborated her husband's story, though under crossexamination denied expecting any compensation for their testimony against Bridges-a statement later contradicted by Leech when he admitted being offered a good job and a new life in Oregon in exchange for an affidavit against Bridges. ${ }^{376}$ Clearly, the government's witnesses

\footnotetext{
373 'Bridges Branded Red at Deportation Trial', Los Angeles Times, July 11, 1939, p. 1.

374 'Bridges Case Witness Tells Red Strategy', Los Angeles Times, July 13, p. 1.

375 'Fear of Reds Told at Trial of Bridges', Los Angeles Times, July 18, p. 1.

${ }^{376}$ Quoted in C. P. Larrowe, 'Did the Old Left Get Due Process-The Case of Harry Bridges', California Law Review, Vol. 60, No. 1, 1972, accessed February 22, 2014 from

http://scholarship.law.berkeley.edu/californialawreview/vol60/iss1/2
} 
had a credibility problem, one that would be fully exploited by Bridges' defence and finally traced to one of the key figures at the secret meeting with Sullivan in July 1938.

That individual was Stanley 'Larry' Doyle, the labour spy and American Legion leader who had been working with Harper Knowles when both men met with Sullivan. Sometimes cooperating, sometimes competing to solicit witnesses with Portland INS official Raphael P. Bonham, Captain Keegan of the Portland PD, and others, Doyle was ultimately responsible for obtaining the testimony of many of the government's witnesses. Shortly after hearings began Bridges' lawyers requested a court subpoena to compel Doyle to testify about allegations of 'improper inducements' offered to some of these individuals to testify against Bridges. ${ }^{377}$ Doyle was missing however, and when finally located in Minnesota refused to appear unless advanced a $\$ 50$ a day fee in addition to compensation for travel time, lost earnings, and other expenses. ${ }^{378}$ While they waited for Doyle to arrive (aided further by a contempt of court order against him), the defence subpoenaed other witnesses, concentrating on several they argued were part of a conspiracy to fabricate charges against Bridges. This group included Harper Knowles, Captain Hynes, and Captain Keegan of the Portland PD, all of whom had aided the House committee to investigate un-American propaganda, either as witnesses or consultants to committee investigators.

The defence case began on August 7, 1939 by summoning to the stand Harper Knowles, the chairman of the Radical Research committee of the California American Legion. The defence wanted to know more about Knowles' role as a leader of the Legion's anti-subversive efforts, which he had been involved with since $1935 .{ }^{379}$ Describing the San Francisco-based committee which he currently chaired as a 'clearing house' for surveillance information on Pacific Coast subversives, Knowles' testimony detailed a node in the surveillance network which functioned similarly to the BAF in Los Angeles and Van Deman in San Diego-though where Van Deman

\footnotetext{
377 'Bridges Trial Featured by Spy Charge', Los Angeles Times, July 29, 1939, p. 1.

378 'Defense Flays Bridges Foe', Los Angeles Times, August 1, 1939, p. 1; 'Bridges Raps Leech Story', Los Angeles Times, August 11, 1939, p. 1.

${ }^{379}$ According to his testimony, the California American Legion committee on radical research was a distinct entity from another organization which Knowles had led called the California American Legion subversive activities commission/committee. Knowles did not provide an explanation for the reorganisation, though one source states that the earlier entity was disbanded after a report from the Department of Labor accusing Knowles of prejudicial attitude and behaviour was given out to Legion delegates at a 1936 convention-Estolv E. Ward, Harry Bridges on Trial, (New York: Modern Age Books, 1940), pp. 11-12.
} 
chiefly drew on military and law enforcement contacts, and the BAF from the patriotic and business world, Knowles claimed to receive much of his information from hundreds of Legionnaires embedded within unions and 'subversive' organisations across California. 380

As Gladstein drew out however, Legion members were not Knowles' only sources. In his testimony Knowles described exchanging surveillance information with the BAF, the State Bureau of Identification, with law enforcement across California and up to Portland, the Immigration Bureau of the Labor Department, and with army and navy intelligence-all of the same sources that Van Deman and other members of the surveillance network were also in contact with. As explained by Knowles, reports would come in to his office from his sources dispersed throughout the state, where they would be summarised and compiled with other related reports. Like Van Deman, Knowles would then have these summaries indexed onto card files, organised alphabetically by the name of the individual or organisation they pertained to. These card files were then used to continue the information exchange-both as detailed reports for Legion commanders and the rank and file, but also as an open surveillance archive accessible by allied organisations. ${ }^{381}$ Of course what Knowles was describing, though he made every attempt to minimise the cooperation and extent of it, was the California surveillance network in action.

Through the network Knowles cooperated with employers' organisations such as the Industrial Association and the Associated Farmers, which accessed his files regularly. Well aware of this history of cooperation, Gladstein and Grossman sought to imply that Knowles was motivated not by anti-communist sentiment as he claimed, but instead was being paid to remove the leader of a resurgent labour movement that had cost Californian employers huge sums of money since his rise to prominence in July 1934. Knowles repudiated this accusation, arguing that the Legion was 'not particularly interested in the union activities of persons suspected of being subversive', and that any anti-labour surveillance the Legion was involved with was merely a by-product of its steady vigil against communist revolution. ${ }^{382}$ Despite this

\footnotetext{
380 Official Report of Proceedings before the Immigration and Naturalization Service of the Department of Labor. In the Matter of Harry Bridges-Deportation Hearing, Boxes 37-40, Dies/NA, pp. 3136-70, [Hereafter referred to as Bridges' Deportation Hearing Transcript]

381 Bridges' Deportation Hearing Transcript, pp. 3150-76, 3321.

382 'Legion Head of Red Enquiry Tells of Bridges Case Survey', Los Angeles Times, August 8, 1939, p. 1.
} 
supposed lack of interest in labour activities, Gladstein drew from Knowles the admission that he had worked for the Associated Farmers directly for three months from June 1, 1938, serving as secretary while continuing to work as chairman of the radical research committee. ${ }^{383}$ Specifically, this meant that Knowles had assisted the Associated Farmers with the collection and archiving of surveillance information on union activities while professing to be apolitical in his attitude towards labour as a Legion anti-communist.

Further exposures about Knowles' anti-labour activities were placed before the court in subsequent sessions of testimony. On the afternoon of August 8 Knowles admitted that he had records on men which contained no details of radicalism at all, instead detailing only their activities and interests in the labour movement. Such files, admitted Knowles, were available to and accessed by the IASF. 384 Some of Knowles' other anti-labour espionage activities were conducted with Doyle in a secret organisation outside of American Legion auspices named the 'Union of California Citizens' [UCC]. Described as a 'bureau for union labor espionage', this group provided Knowles and Doyle with a vehicle through which to pursue the anti-labour surveillance they could not openly do for the Legion. ${ }^{385}$ An affidavit signed by an Industrial Association spy named Herbert Mayes claims that he joined this secret group when it was formed in February 1937. Made up of IASF spies and other select individuals affiliated with the Legion's anti-subversive work, the UCC was financed by the IASF, by shipbuilders, and by other employers' organisations, holding its meetings in the San Francisco Chamber of Commerce building. In addition to placing informants within unions to file reports on internal activities, the secret group were also actively involved in trying to influence union votes. As related by Mayes, UCC members aided conservative union officials using forged (or stolen) membership books to stack votes in favour of anti-CIO, anti-Bridges, or pro-AFL resolutions. ${ }^{386}$

Other testimony that was sometimes painfully extracted from the defence's adverse witnesses revealed a fragmented coalition riven by suspicion of the motives of the other participants. For example, when Portland PD Captain Keegan was brought to the stand he was

\footnotetext{
383 Bridges' Deportation Hearing Transcript, pp. 3174-75.

384 Ibid, pp. 3429-35.

385 'Bridges' Defense Accuses Knowles of Union Espionage', Los Angeles Times, August 31, 1939, p. 8.

${ }^{386}$ Affidavit of H. G. Mayes, January 8, 1939, Box 1, CSC/SFSU; This affidavit was not part of the Bridges deportation hearing, but is discussed here to provide further illustration.
} 
repeatedly challenged about alleged outside funding he had received to pursue evidence against Bridges. A former AFL teamster leader named Albert Rosser corroborated these charges, testifying that $\$ 1000$ had been paid to Keegan by an AFL rival of Bridges to press the investigation of Bridges. Rosser also produced what he claimed was a receipt for a further $\$ 250$ to Lieutenant Browne, one of Keegan's deputies who headed the equivalent Legion anti-radical bureau in Oregon to the one Knowles ran in California. ${ }^{387}$ Privately, Keegan accused his fellow Legionnaire and co-conspirator Doyle of harbouring his own mercenary agenda. As Keegan wrote, 'friendly relations with Doyle are out', 'I doubt the statement of Doyle that he doesn't expect pay [...] if I ever did have confidence in Doyle, that has been shaken and broken'. ${ }^{388}$ If Doyle's and Keegan's motivations were financial, then what were the motivations of those witnesses from whom they had allegedly solicited affidavits in return for improper inducements'? More immediately, what role had Doyle played in the case against Harry Bridges?

In Doyle's absence, Gladstein and Grossman heard testimony about the improper inducements that he was alleged to have made to witnesses to sign manufactured affidavits asserting Bridges' CP membership. Two incarcerated witnesses alleged that Doyle had promised to have each released from prison in exchange for false affidavits against Bridges, and had threatened to 'hang another murder' on one of the men if he did not cooperate. ${ }^{389}$ Another witness testified that he overheard Lieutenant Browne of the Portland PD making an unsuccessful offer of $\$ 10,000$ to John Leech for an anti-Bridges affidavit, while Knowles conceded that Doyle's own attempts to secure Leech's affidavit may have been because of the offer of a new car, a job in Portland, and the funds necessary to relocate his family there. ${ }^{390}$ Knowles also admitted that it 'was possible' that Doyle had offered money in exchange for an affidavit from at least one other witness, and had definitely secured a valuable AFL job for another. ${ }^{391}$ Knowles further testified that in June 1938 (a month before the meeting with Sullivan), Doyle had himself begun receiving money from the IASF, payment for investigative

\footnotetext{
387 'Bridges Hearing Ends with Witness Unheard', Los Angeles Times, September 12, 1939.

388 'Secret Police Letters Offered', Los Angeles Times, August 11, 1939, p. 4.

389 'Bridges Case Threats Told', Los Angeles Times, August 26, 1939, p. 6.

390 'Woman Aids Bridges' Case', Los Angeles Times, August 25, 1939, p. 20; Bridges' Deportation Hearing Transcript, pp. 3478-81.

${ }^{391}$ Bridges' Deportation Hearing Transcript, pp. 3420-25, 3467-8.
} 
work that Knowles struggled to deny was in pursuit of Bridges. ${ }^{392}$ Clearly the defence sought to establish that money was paid to build the case, and that the credibility of witnesses with whom Doyle had contact was thus in doubt.

A letter written by Doyle to Sullivan a year earlier provides further details about his role in the case. ${ }^{393}$ In it Doyle credits himself as the key figure in recruiting the majority of witnesses who signed affidavits and gave testimony asserting Bridges' $\mathrm{CP}$ membership, which were presented both before the Dies committee and later in the deportation hearings. ${ }^{394}$ In Doyle's own words, 'I am the person who obtained the first eleven (11) witnesses against Bridges and if you will read the affidavits you will note that my name appears as a witness in the statements of Scott, Arthur, John Leech and his wife, Herbert Mills, Ivan Cox and his wife and Major Milner' ${ }^{395}$ Of Doyle's named witnesses above, all were shown to be unreliable witnesses during the hearings, either because of inducements offered to them, because of their background as labour spies, or because of prior criminal behaviour including perjury, embezzlement, and burglary.

Doyle further claimed that he was the authentic source for some of the evidence against Bridges that was credited to others before the Dies committee. This included, for example, the CP membership book ascribed to Bridges that was presented before the Dies committee by Margaret Kerr in August 1938. Bragging that he was 'the only person who can prove that the "Harry Dorgan" membership book that was removed from Bridges' effects was his', Doyle claimed to have obtained the book as part of an operation to eavesdrop on Bridges while he stayed in a Portland Hotel during June 1937.396 According to Doyle, the dictograph he installed had recorded 'several top CP fraction meetings' held by Bridges, and when Doyle had the room 'prowled' afterwards the Harry Dorgan membership book was discovered.

\footnotetext{
392 Ibid, pp. 3344-48.

393 This letter was not available to the defence during Bridges' deportation hearing, but is discussed here by way of illustration.

394 Letter from Stanley Doyle to Edward Sullivan, August 27, 1938, Box 11, Dies/NA.

${ }^{395}$ Key government witnesses in the deportation hearings prepared by Doyle included John Leech, Mary Leech, Ivan Cox, J E Ferguson and Laurence Milner-Letter from Stanley Doyle to Edward Sullivan, August 27, 1938, Box 11, Dies/NA.

${ }^{396}$ Letter from Stanley Doyle to Edward Sullivan, August 27, 1938, Box 11, Dies/NA.
} 
If Doyle's claim is truthful, then this membership book (or a photostat copy of it) must have been passed to the BAF at some point in late 1937, after which a backstory was invented assigning its provenance to Markheim. This would then mean that at least part of the Markheim affidavit presented to the Dies committee must have been fabricated, since Markheim could not have obtained the book while undercover in the Los Angeles CP if Doyle had retrieved it from a Portland hotel. According to his testimony, Bridges had discovered the dictograph before these supposed recordings were made, and described putting on a show for the listeners on the other end. ${ }^{397}$ Why then would he leave a genuine document linking him to the $\mathrm{CP}$ in his room if he was aware he was being surveilled? When these issues are considered together with what else is known about Doyle, it seems more plausible that Doyle arranged to have the book manufactured, planted in the room and then discovered by Portland PD to give the appearance of having come from Bridges himself.

Doyle claimed that Albert Mattei, head of the Pacific Coast Waterfront Employers' Association, had promised to pay for this investigative work on Bridges. However despite the supposed success of Doyle's investigation, Mattei refused to pay the promised amount which Doyle claimed to be in excess of $\$ 150$ in addition to compensation for five weeks of Doyle's time. Doyle's explanation was that Mattei 'cherished a strong personal dislike and hatred' for him, 'to the point where on sundry occasions he has made nasty slanderous and lying statements' accusing Doyle of 'extortion, blackmail, and other felonies' ${ }^{398}$ Doyle explained to Sullivan that it was because of his negative experiences at the hands of Mattei that he had decided against testifying before the House investigative committee.

His mind made up, Doyle advised Sullivan not to rely on him to aid the committee anymore, as he had destroyed his files, 'cleaned his hands of the whole mess', and moved to Minnesota. ${ }^{399}$ If true, this decision might have undermined the coalition's ability to present evidence against Bridges, and may have also been a factor in Knowles' decision to not present their full case before the Dies committee in November 1938. Alternatively, perhaps Knowles

\footnotetext{
397 'New Threat Related by Bridges Witness', Los Angeles Times, August 10, 1939, p. 1; A letter from Doyle to Sullivan also records Bridges' discovery of the dictograph, but states that he 'honestly believe[s] we have Bridges nailed' regardless, perhaps as a result of the CP book-Stanley Doyle to Harper Knowles, c. June 1937, Box 3, CSC/SFSU.

398 Letter from Stanley Doyle to Edward Sullivan, August 27, 1938, Box 11, Dies/NA.

399 Ibid.
} 
and the others had pushed Doyle out so as to limit any potential fallout from his involvement with the case.

Though Gladstein and Grossman had agreed to compensate Doyle in exchange for his testimony, by the hearing's close on September 11, 1939 he had still not arrived. ${ }^{400}$ The man who had been described as the 'mainspring' of the government's case had managed to dodge a succession of subpoenas and contempt orders compelling his appearance. ${ }^{401}$ When Doyle finally did appear in San Francisco a few days after the hearings closed, he was jailed on an outstanding warrant for battery of the ACLU director who had photographed Doyle while he was surveilling a picket in April 1938. ${ }^{402}$ At first Doyle claimed he would give a deposition in exchange for further compensation, a proposal at first granted at the expense of the defence, but then Doyle reneged on the deal, claiming he would only testify in open court. Exasperated, the defence gave up trying to secure his testimony, and the hearing was adjourned while Landis considered his decision. ${ }^{403}$

Having woven together a complex and dizzying argument, the defence's case ultimately rested on establishing that a conspiracy had existed to deport Bridges involving Pacific Coast employers' associations, surveillance operatives, immigration officials, and certain members of law enforcement, which relied on affidavits purchased from mercenary witnesses. As defence attorney Richard Gladstein argued, if a 'case is prepared outside of the prosecutor's office by improper methods and then is presented to the prosecutor and taken by him into court, he must be tainted if there is any taint in the preparation of the case. Our contention is that the United States government did not prepare this case' ${ }^{\prime}{ }^{404}$

The principal grounds for considering Bridges' deportation, as defined by the Immigration Act of 1918, were allegations that Bridges was then a 'member of' or 'affiliated' with an organisation that sought the violent overthrow of the government of the United States. In order to successfully argue their case, the government was required to prove both of two

\footnotetext{
400 'Landis target of threateners', Los Angeles Times, September 7, 1939, p. 10; 'Bridges Hearing Ends with Witness Unheard', Los Angeles Times, September 12, 1939, p. 12.

401 'Bridges Trial Gets Surprise', Los Angeles Times, August 18, 1939, p. 1.

402 'Long Sought Bridges Case Witness Reaches Bay City', Los Angeles Times, September 13, 1939, p. 8.

403 'Doyle Upsets Bridges Cases', Los Angeles Times, September 14, 1939, p. 8; 'Dispute Ends Bridges Case', Los Angeles Times, September 15, 1939, p. 11.

404 'Legion Head of Red Enquiry Tells of Bridges Case Survey', Los Angeles Times, August 8, 1939, p. 1.
} 
charges: first, that Bridges was a member of or affiliated with such an organisation when the warrant was served on him in March 1938; and second, that this organisation did in fact advocate or directly work towards the violent abolition of the government of the United States.

On December 29, 1939 Judge John Landis ruled that the government had failed to show adequate grounds for deportation. In a letter to Secretary Perkins explaining his decision Landis wrote that, on the evidence submitted, it was not possible to conclude that Bridges was affiliated with such an organisation in March 1938. As a result, a ruling on the second charge, that the CP advocated the overthrow of the U.S. government was unnecessary. ${ }^{405}$ Bridges, Gladstein and Grossman had won. The Los Angeles Times editorial which followed called Landis' decision an 'affront to common sense', and argued that only a 'newdealistic mind' like Landis' could privilege the word of an 'alien agitator' over the word of 'reputable police officers' and Raphael Bonham of the INS. ${ }^{406}$

The defence had built a credible case. But how did Bridges' defence attorneys piece together this information to such an accurate extent, and where did they obtain the correspondence from Knowles and law enforcement officials that had so unsettled Keegan, Knowles and others while on the witness stand? When this evidence was introduced during the hearing by Bridges' lawyers they refused to disclose their sources. ${ }^{407}$ The evidence submitted included, for example, a letter (and its reply) from Knowles to Hynes of the LAPD enquiring about the possibility that Leech might testify against Bridges. ${ }^{408}$ This was used by Gladstein and Grossman to prove that Knowles had cooperated with other interested parties in the development of witnesses that he had initially denied being involved with. As Knowles had implied during the hearing, some of these documents may have been obtained illegally by an undercover operative of Gladstein and Grossman.

According to a few obscure reports, a pro-union janitor working in Knowles' building had secreted a number of files from his office during the night, passing them to staff at Gladstein

\footnotetext{
405 'Bridges absolved of Red Charges', Los Angeles Times, December 30, 1939, p. 1.

406 'An Affront to Intelligence', Los Angeles Times, December 31, 1939, p. A4.

407 'Bridges Case Documents Disappear', Los Angeles Times, August 12, 1939, p. 1.

${ }^{408}$ See, for example-Bridges' Deportation Hearing Transcript, pp. 3320-28.
} 
and Grossman to be hastily copied and replaced before the morning. ${ }^{409}$ After the defence had begun producing these letters Knowles himself had made a point of showing some of the originals to Landis, arguing that the marks in the corners showed that they had been made when 'purloined for copying purposes'. ${ }^{410}$ This story is consistent when checked against what remains of the Knowles' correspondence in the records of the law firm where Gladstein and Grossman worked-most of the documents are photostats of missing originals, and several of these include marks in the corners where staples or other attachments may have been removed prior to copying. ${ }^{411}$

An openly pro-Bridges account of the hearing is given in Estolv Ward's Harry Bridges on Trial, in which the files of Gladstein and Grossman are briefly described at the close of the trial. ${ }^{412}$ Finally yielding to a reporter's questions about the mysterious suitcases that he and Grossman had by their side throughout the hearing, Gladstein explained that 'we've lugged this stuff around and watched it like hawks because it only took a year and a half to get it together $[\ldots]$ it was mighty precious information'. ${ }^{413}$ The suitcases were filled with row upon row of card files, indexes to a massive research archive assembled over several years in anticipation of an attempt by anti-labour conspirators to have Bridges deported. This archive contained far more than was ever revealed in the trial, including details of payments by the LAPD to its undercover informants, correspondence between Van Deman, Knowles, the BAF, law enforcement throughout California and Oregon, the ONI, the CCD, and countless others, amounting to many thousands of documents authored by or corresponding to members of the California surveillance network. ${ }^{414}$ It is clear that this huge mass of material could not have been copied through the efforts of a lone janitor, no matter how furtive his labour.

\footnotetext{
409 The details of this explanation are vague, but see-'Inventory of the Norman Leonard Papers', September 2011, Labor Archives and Research Center, San Francisco State University, p. 12.

410 'Bridges Defense Accuses Knowles of Union Espionage', Los Angeles Times, August 31, 1939, p. 8.

${ }^{411}$ See Harry Bridges Case Files, Norman Leonard Papers, Labor Archives and Research Center, San Francisco State University, [hereafter referred to as Bridges/Leonard/SFSU].

${ }^{412}$ Estolv E. Ward, Harry Bridges on Trial, (New York: Modern Age Books, 1940). Alongside Bridges and his defence team, pro-union journalist Ward was described as a 'stooge' of the Communist Party by a government witness at the hearings named Miles Humphrey-'Witness says Bridges' Counsel Communists', Los Angeles Times, September 1, 1939, p. 13.

413 Ward, p. 225.

${ }^{414}$ See, for example-Letter from Harper Knowles to Ralph Van Deman, January 25, 1937, Box 1,

Bridges/Leonard/SFSU. Mirroring his own setup, Gladstein \& Grossman had a card file index with several entries on Van Deman. References on those cards summarised correspondence in the larger archive between Van Deman and
} 
It is extremely likely that the NLRB or the La Follette committee itself was an additional source for the material. According to a later statement by William Hynes, LAPD documents subpoenaed and copied by NLRB lawyer David Sokol while he was investigating on behalf of the committee were never returned. ${ }^{415}$ When directly challenged, Sokol denied giving them to Bridges' defence team, claiming instead that he had forwarded all material to the committee headquarters in Washington. ${ }^{416}$ Perhaps somewhere in these files were hints of Hynes' involvement with the secret meeting with Sullivan that occurred in San Francisco in July 1938, as a subpoena sought by Bridges' defence and issued by Landis demanded that the LAPD turn over any documents 'connected in any way with the holding of conferences or meetings or plans which in any way relate to an investigation of Bridges' ${ }^{417}$ Also in the law firm's archives are volumes of material from LAPD files, plainly copied using a different process than the majority of the files within the archive, suggesting different equipment than what was used by the legal firm of Gladstein and Grossman. Notations on some of these files indicate that they were copied in January 1939, during the period when Sokol had access to these files as a La Follette investigator. ${ }^{418}$

Yet Gladstein and Grossman did not publically identify all of the participants in the effort to deport Bridges, despite having in their possession a few traces of wider involvement. It is likely that they suspected involvement from other groups, but chose to focus their exposures on the immediate group around Knowles, who were certainly vulnerable to accusations of impropriety. Though they undoubtedly played a more passive role than this group, other participants included many members of the wider Californian surveillance network, including Van Deman, the SDPD, and the Long Beach CCD. To give one example, a police report Van Deman received from the SDPD dated October 9, 1938 records the involvement of all of these groups in attempts to identify and track down one Charles Cartright 'who is said to have been a body guard of Harry Bridges at one time and has since turned RIGHT and may be a good

various of his contributors, including one with Hynes dated August 1936, discussing the importance of a Californiawide 'clearing house' on Communism. For the card file index, see Box 25, Bridges/Leonard/SFSU.

415 'Says Communist got police files: Ex-Los Angeles Officer tells why documents wanted at Bridges trial are lost', New York Times, May 14, 1941, p. 16.

416 'Secret Police Letters Offered', Los Angeles Times, August 11, 1939, p. 4.

417 'Bridges Case Documents Disappear', Los Angeles Times, August 12, 1939, p. 1.

${ }^{418}$ See, for example-letter from anon. to Chalmers Graham, November 14, 1936, Box 8, Bridges/Leonard/SFSU, which indicates that the file was copied from LAPD files on January 18,1939 by F. L. Ryan, presumably one of Sokol's assistants. 
witness against BRIDGES'. ${ }^{419}$ A document in Knowles' archive confirms that he had originated the search with the CCD, which was investigating the possibility that Cartright might contact relatives living in Long Beach. The CCD sent a request for help to William J. Macy of the SDPD, who passed it on to Van Deman, presumably so he could use his own voluminous files to help locate the potential witness. ${ }^{420}$ Though this individual never played a part in the trial, it clearly demonstrates that the common goal of deporting Bridges was shared by many, if not all parts of the network.

The Los Angeles Times recognised the wider political context of the trial, and of the mysteriously obtained surveillance material underpinning the case, describing the hearing as a 'sub-clash of the La Follette and Dies committees' investigations. ${ }^{421}$ During the trial Gladstein and Grossman had used that same comparison to attack their opponents, arguing that 'the same people [were] gathering the same evidence for the Dies Committee and the Bridges case, for the same purpose-discrediting Bridges and the unions'. ${ }^{222}$ This chapter has shown that they were right, but is has also shown that Gladstein and Grossman were the beneficiaries of evidence collected by their own allies at the La Follette Civil Liberties committee. What the document trail makes clear is that both committees and their investigative staff drew on local resources and sympathetic personnel in their California investigations, which included the surveillance network on the right, and the NLRB, CIO, and probably the CP on the left. In this way both committees became representative of particular strands of the American politic, acting as public magnets for allied or sympathetic individuals and causes.

\section{A Blur through the Scope}

\footnotetext{
419 'Officer's report concerning radical activities', October 9, 1938, R-2765, Box 21, RHVD/NA.

${ }^{420}$ Ibid; Van Deman was also collecting information at that time on Bridges' defense counsel, who he received reports on in October 1938, just as the Dies committee's pressure for deportation hearings was starting to produce results - Report on Aubrey Grossman, June 1936, R-2759a, Box 21, RHVD/NA; Report on Richard I. Gladstein, December 1936, R-2759b, Box 21, RHVD/NA.

421 'Row Flares over Bridges Trial Letters', Los Angeles Times, August 9, 1939, p. 1.

422 Gladstein quoted in Estolv E. Ward, Harry Bridges on Trial, (New York: Modern Age Books, 1940), p. 89.
} 
In the second half of the 1930s a large shift took place in the categories of suspicion applied by Van Deman and the contributors to his archive, affecting the targets selected for surveillance. When Chart 2.3 (Chapter 2, p. 101) is compared to Chart 3.2, below, this shift can be observed.

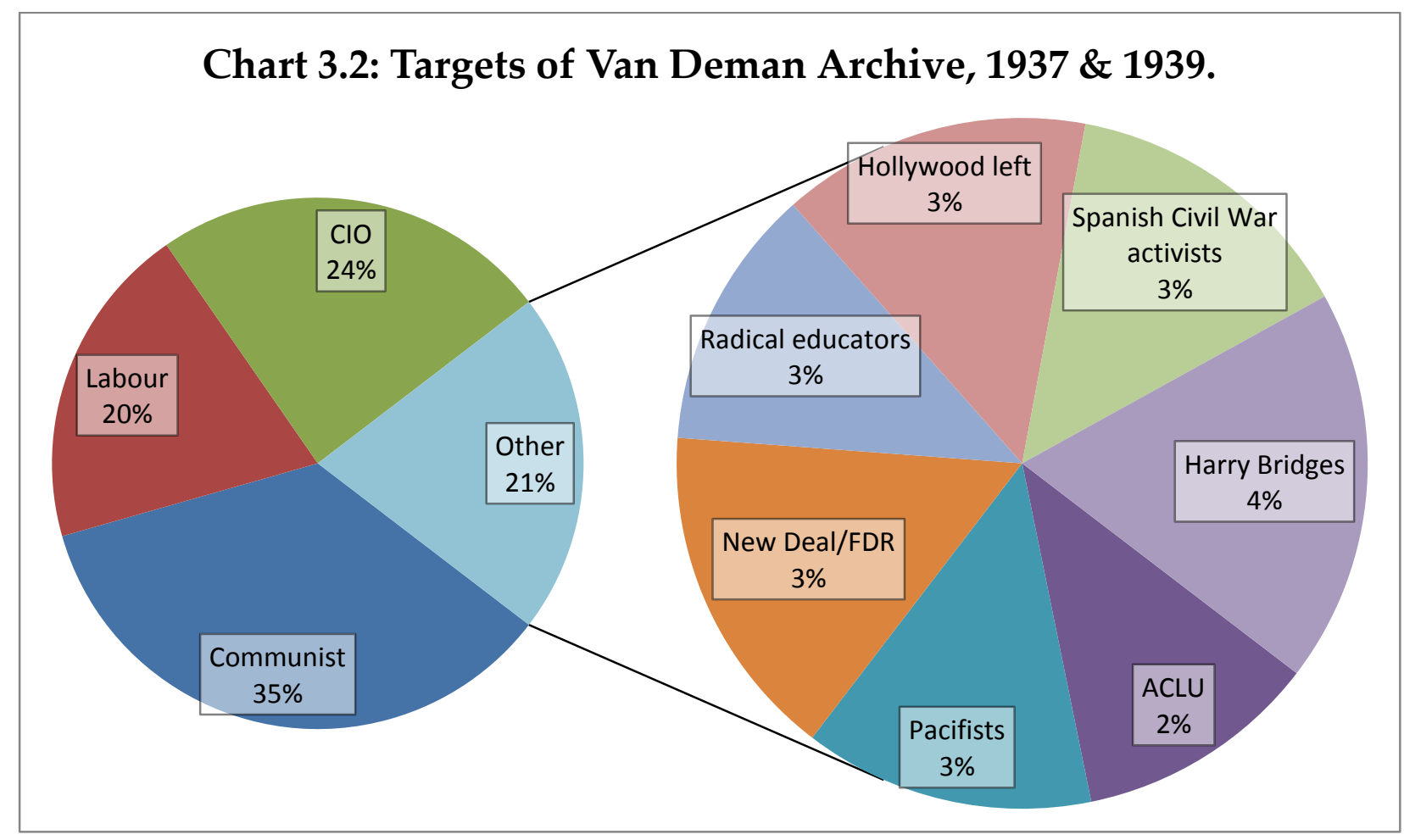

Though Communists remained the largest single target of surveillance in 1937 and 1939, attracting thirty-five per cent of attention across both years, figure six records the increasing shift towards surveillance of labour organisations, with non-CIO or unaffiliated labour organisations the target of twenty per cent of texts across those years. The $\mathrm{CIO}$ wing of the movement attracted even greater attention, either directly or through its affiliated unions, as the target of approximately twenty-four per cent of all texts stored in VD's archive during 1937 and 1939. The increased threat of communist infiltration into moderate labour organisations as part of the CP's popular front strategy after 1935 is undoubtedly the cause of some of this increased attention on labour movements, especially when followed later by suspicion that the CIO was a communist-controlled entity, however this only partly explains the shift.

The more significant factor is likely the diversification of individual motivations that came with the expansion of Van Deman's contributors. Some of these groups, such as the Industrial Association, the Associated Farmers, and American Legion (through Harper Knowles), were 
exposed by their opponents as being involved in anti-labour espionage irrespective of whether the $\mathrm{CP}$ was present as a 'legitimate' target of surveillance. In the most immediate sense, Van Deman's archive records increased anti-labour activity after 1935 because these new groups that he was in contact with utilised the network to gain better information on their labour antagonists, passing that information to allies in the business world. This provided California employers with the ability to better disrupt organisation efforts, undermine strikes, and generally maintain control over their workforce, ensuring that profits were protected.

Beyond the pure profit motive, there was also an inquisitional tone to the surveillance of the labour movement. After the high-profile San Francisco general strike of 1934, the San Joaquin and Imperial Valley agricultural strikes of 1934 and 1935, and the on-going unrest on the waterfront, much of the Californian surveillance network seems to have become overwhelmingly focused on rooting out communists among the labour movement. Often these types of enquiry had useful political functions, particularly when Democratic Party staff or politicians accepted favours from groups who were under surveillance for suspected radicalism - though these types of revelations seldom, if ever, turned up evidence of direct $\mathrm{CP}$ connections, the innuendo and implications they generated were enough to justify their continuance. In these and other ways, exposing communists among labour unions was an effective tool of both conservative public relations and strikebreaking. Van Deman's collaborations with these groups are undoubtedly reflected in Chart 3.2.

Also significant was the pursuit of evidence against Harry Bridges that probably the entire surveillance network participated in after 1935. Though not reflected directly in the relative percentage of texts targeted at him (only four per cent), many CIO or labour surveillance texts bore signs of an underlying attempt to understand the internal labour situation on the West Coast, particularly regarding the movement of unions out of the AFL and into the more radical $\mathrm{CIO}$. When Bridges' role as a $\mathrm{CIO}$ organizer is coupled with the avowed belief held by many of the surveillance network that both he and the $\mathrm{CIO}$ were communist controlled, it is possible to read the network's attention to the movement of unions as an attempt to gauge the depression-era labour movement's revolutionary temperature.

Despite the clearly pro-capital, anti-labour agenda of many of the partners and contributors to his archive, it appears that Van Deman himself remained at least partly 
motivated by a conviction that the CPUSA posed a genuine, revolutionary threat to what he held to be the American way of life. For example, texts concerning the seven secondary targets represented in Chart 3.2 typically sought to test the organisations concerned for communist affiliation or infiltration. Occasionally these texts displayed an almost paternal concern for the naiveté of individuals who the authors believed had been duped into mimicking a CP position, as for example much of the surveillance of the Hollywood left. ${ }^{423}$ At its worst, this type of surveillance exerted a shrinking effect on the possible political spectrum in California, as it sought ways to publically discredit any of these groups that could be linked to communism. In many ways this was a continuation of the BAF's denunciations of reformists as 'Parlor Bolsheviks' during the 1920s - characterising challengers to the status quo as effeminate leftists without the courage to put their lives on the line and become public radicals. This was particularly true of texts targeting the New Deal, Radical educators, Spanish Civil War Activists and the ACLU.

At the end of 1939 James Steedman, who had replaced Sullivan in 1938 as California investigator for the Dies committee, sent out a few select letters to trusted friends and allies of the committee in California. The recipients of these letters were Harper Knowles of the American Legion, Kendall Dazey of the Industrial Association, General Van Deman in San Diego, and Margaret Kerr of the BAF. ${ }^{424}$ Over the previous few months Steedman had visited California himself, travelling between San Francisco, Los Angeles, and San Diego to visit these members of the surveillance network with whom he had been in contact. Describing his consultations with Kerr during that time, Steedman wrote to Stripling to inform him that Margret Kerr 'has been of tremendous assistance to us in that she has files and records that have been compiled over a period of years [...] records [that] have assisted us materially in our present investigation'. ${ }^{425}$ For her service Kerr received a letter from Chairman Dies thanking her personally. ${ }^{426}$

\footnotetext{
${ }^{423}$ In some of these texts can be seen a foreshadowing of the post-WWII entertainment industry blacklists, and the clearance-for-sale process that accompanied it. For examples of this type of surveillance, see R-2767b, Box 21, RHVD/NA.

${ }^{424}$ There was one other recipient, a man unknown to this author-'Don Larkins' of Los Angeles.

425 Letter from James Steedman to Robert Stripling, September 18, 1939, Box 9. Dies/NA.

${ }^{426}$ Letter from Martin Dies to Margaret Kerr, September 15, 1939, Box 9, Dies/NA.
} 
In his letter to Van Deman Steedman cast his eyes over the future years ahead, stating he felt optimistic about the prospect of the Dies Committee being able to secure an additional year's funding as 'the country was behind the committee', even if the left-wing in Washington were 'doing all in their power to stymie a new appropriation'. ${ }^{427}$ He closed his letter with a final solicitation for information, instructing Van Deman (as he did in the letters to the other recipients of his letters) to continue sending any surveillance information 'that you think might be of service' to the committee. At that time, Steedman believed that the Dies Committee mandate would expire on January 3, $1940 .{ }^{428}$ Of course Steedman could not have known that the Dies Committee would indeed receive appropriations to continue its work, and that during the course of the war it would evolve into one of the most politically powerful and historically influential standing committees of the immediate post-WWII years.

427 James Steedman to Ralph Van Deman, December 28, 1939, Box 9, Dies/NA.

428 James Steedman to Margaret Kerr, December 28, 1939, Box 9, Dies/NA. 


\section{Conclusion}

During the second half of the 1930s the Californian surveillance network struck back at its opponents and the New Deal to help launch the national conservative resurgence of 1938. They did this through repeated exposures of the tactics and activities of their opponents at both at the state and national levels. The Los Angeles Times contributed to this effort by regularly hosting attacks on the Democratic Party, the $\mathrm{CIO}$, the $\mathrm{CP}$, and representatives and agencies of the New Deal. The Dies Committee gave the surveillance network a national platform for its surveillance data, and encouraged new alliances with groups who shared its concerns about labour militancy and the $\mathrm{CP}^{\prime}$ s activities in California.

Locked in ideological and intelligence-gathering competition, a left-wing network also emerged during the second half of the 1930s, anchored by the La Follette committee and the NLRB. Their investigations turned up an immense amount of material detailing the violations of the rights of labour, often at the hands of employers' groups connected with, if not members of, the California surveillance network. Despite these successes, the committee increasingly found itself on the losing end of public feuds with their rival committee, exacerbated by the conservative counteroffensive against the New Deal to which the Dies committee had contributed.

Denied the public outlet that committee hearings promised, the Californian left instead found another public outlet in the deportation hearing of Harry Bridges. The exposure generated by this hearing proved to be especially uncomfortable for certain anti-labour sections of the surveillance network, especially Harper Knowles, Stanley Doyle, and the employers' organisations with which they worked. The conspiracy which the hearing exposed stretched further than Gladstein and Grossman had even uncovered, yet the material they managed to assemble was enough to undermine the case prepared by the network and prosecuted by Raphael Bonham and the Department of Labor. Landis' decision in favour of Bridges was a victory, but a temporary one, which in 1940 would be tempered by Washington legislators eager to find a permanent solution to Bridges and the wider CIO-led challenge to American labour that he represented. 
In the years between 1936 and 1939 Van Deman and the other members of the network spent an increasing amount of time engaged in surveillance of workers and labour movements, especially CIO unions within California's aircraft industry. Many than any other factor, this was a product of the growth of the network after 1934-which saw increasing contact with employers' organisations such as the San Francisco Industrial Association and the Associated Farmers of California. For Harper Knowles and his business and law enforcement allies, a major goal after 1934 was to secure evidence that could be used to deport Harry Bridges. As the 1939 deportation hearings showed, the financial value attached to that goal became too tempting for Doyle and others to resist. Their decision to provide improper encouragement to witnesses willing to testify against Bridges undoubtedly contributed to the government's failure to prove sufficient grounds for deportation. This mercenary legacy followed the California surveillance network into the post-war period, when the nation was once again whipped up into a renewed communist scare by individuals who personally gained from the chaos. 


\section{THESIS CONCLUSION}

In August 1939 the U.S. Senate finally voted to give the La Follette Civil Liberties Committee the extra funding they needed to hold hearings in California. ${ }^{429}$ Those hearings began in earnest in Los Angeles on November 25, 1939 continued in San Francisco through December, and then returned to Los Angeles from January 10 to January 24 . The publicity the hearings generated allowed members of the California left to continue the momentum they had accumulated during the Bridges hearing, generating further exposures about the anti-labour practices of the Industrial Association, the Associated Farmers, the LAPD, and many other participants in or allies of the California surveillance network. The transcripts of these hearings are a recognised source for historians of California and organised labour.

Partly as a result of the committee's enquiries Californian employers, particularly in Los Angeles, began to make further concessions to labour unions, leading the AFL to declare in 1941 that the 'Citadel of the Open Shop' had fallen. ${ }^{430}$ Later volumes of La Follette reports disclosed the results of the investigations as they appeared between 1940 and 1944, but the hoped for enhancement of protections to the right to organize could not be achieved. Ultimately the surveillance network's allies in the state and nationally prepared the way for the postwar anticommunist offensive which eroded the NLRA and intensified the anti-communist hunt. California farmworkers would remain without protected collective bargaining rights until the passage of the California Agricultural Labor Relations Act in 1975, itself rendered possible only by strikes and other industrial actions taken by the United Farm Workers and other inheritors of the legacy of the CAWIU.

Picking up where they had left off in 1938, Dies finally held Los Angeles hearings in July 1940, much of which was directly targeted at the film industry. In executive session, Dies, J. B. Matthews and Robert Stripling interrogated Humphrey Bogart, James Cagney and other movie

429 'Civil Liberties Investigation for Pacific Coast Assailed', Los Angeles Times, August 5, 1939, p. 4.

${ }^{430}$ Quoted in Scott McLellan, 'Policing the Red Scare', p. 187. 
tough guys about their political beliefs. ${ }^{431}$ John Leech, the former Los Angeles CP member whose two contradictory affidavits about Bridges had helped to undermine the government's deportation case, appeared again before the Dies committee as an expert witness on communists in Hollywood. Leech's testimony in closed session on July 16, 1940 was repeated before a grand jury in August 1940, during which his allegations about the CP membership of specific individuals were probably deliberately leaked to the press, initiating the era of the entertainment industry blacklist.

The Second World War disrupted the activities of the Californian surveillance network in many ways. For one thing, Martin Dies had retired from Congress after a vengeful CIO strengthened by popular support found a candidate to oppose him for his Texas seat. Without their political patron the surveillance network lacked an output for all the information they were continuing to collect on political subversives. With the war raging, the unfinished business of exposing the Communist Conspiracy in Hollywood would have to wait, especially since many of those Communists were making films to promote the war effort against fascist Germany.

Californian anti-communists were in some ways a victim of their own successes. Through his close ties with the Federal government, Van Deman had finally succeeded in alerting government spies to the threat presented by domestic subversives, and with the United States at war on two fronts, agencies such as the FBI and G-2 decided the threat could no longer be managed by amateurs, regardless of their credentials. Though still a key node in the network, Van Deman's resources and contacts were co-opted by this Federal effort, which placed an emphasis on ethnicity in target selection rather than political sympathy. As he had done during WWI, Van Deman spent the war engaged in the surveillance of hyphenated Americans on behalf of the US government.

On Van Deman's death in 1952, the archive he had created was split up, with the major part going to the U.S. Military after the FBI had declined to accept Van Deman's wish for it to be incorporated into their files. Stored at the Presidio in San Francisco until the 1960s, it was

\footnotetext{
${ }^{431}$ His work for the Dies committee was another step in J B Matthews ascendancy to the top strata of American anti-communism. For a brief account of Matthews' career, see Robert M. Lichtman, 'J. B. Matthews and the 'Counter-subversives': Names as a Political and Financial Resource in the McCarthy Era'. American Communist History, Vol. 5, No. 1 (June 2006), pp. 1-36.
} 
accessed occasionally by state authorities, the FBI, and Military Intelligence. The other portion remained in private hands in San Diego, where National Guard Colonel George Fisher took ownership. Until 1962 Fisher housed the archive in the National Guard armoury there, until Governor Edmund Brown seized the files on the pretext that they had been used to smear Democratic candidates in state elections. ${ }^{432}$ Harry R. Haldeman, grandson of the BAF founder and aide to Richard Nixon, helped fundraise for a legal suit to secure the archive's recovery, which perhaps lends credence to accusations that Nixon's campaign staff used material from the archive to smear Jerry Voorhis and Helen Douglas in 1946 and 1950.433

Passed into law on the $2^{\text {th }}$ of June, 1940, the Alien Registration (Smith) Act supplied Bridges' antagonists with a second chance to deport the union leader. In many ways the Smith Act sought to do on a national level what the Criminal Syndicalism Laws did on a state-by-state basis at the end of the First World War. Just as surveillance organisations and their political allies had used the CS laws to enforce the permitted spectrum of politics in California, the Smith Act did the same at the national level. Even more than the CS law the Smith Act had a specific set of targets, and was admittedly amended to provide Bridges' antagonists with an enlarged set of conditions under which they could deport him. ${ }^{434}$

With this act in hand, prosecutors now only had to prove Bridges had, 'at the time of entering the United States, or ... at any time thereafter', been a member or affiliated with the Communist Party. ${ }^{435}$ Subsequent hearings ending in June 1941 recommended his deportation, a decision reversed on appeal but overruled by the Attorney-General, which generated a final appeal to the Supreme Court. In 1945 the country's highest court finally ruled in favour of

\footnotetext{
432 On the fate of the archive, see-'Row rages on Removal of "Red" files: General threatens Suit over Ation by State Official', Los Angeles Times, February 16, 1962, p. A1; 'Seized Files Remain Locked in Mystery, Aides don't know who has keys', Los Angeles Times, February 20, 1962, p. A1; 'Seized Files Stir New Coast Clash', New York Times, June 21, 1962, p. 11; 'Senate Panel Holds Vast "Subversives" File Amassed by ex-Chief of Army Intelligence', New York Times, September 7, 1971, p. 35.

${ }^{433}$ H. R. Haldeman to Victor John Krehbiel, re: San Diego Research Library files, June 16, 1962, Box 60, Folder 21, White House Special Files Collection, Richard Nixon Presidential Library, Yorba Linda.

${ }^{434}$ The author of an amendment to the bill explicitly said so before congress, stating that 'this bill changes the law so that the Department of Justice should now have little trouble in deporting Harry Bridges and all others of similar ilk' - quoted in Walter Murphy, Elements of Judicial Strategy, (Chicago: University of Chicago Press, 1964$),$ p. 189. Also see Richard Steele, Free Speech in the good war, (New York: St. Martin's Press, 1999, p. 81.

${ }^{435}$ A crucial legal point in the 1939 hearings was that the government needed to prove Bridges was a member or affiliated with the CP in March 1939, at the time the warrant was served. Even if he had been head of the CPUSA in 1934, for example, that would not be sufficient grounds for deportation if he had severed all contact by March 1939.
} 
Bridges, effectively ending that phase of the campaign to deport him that had begun soon after July 1934. In his opinion Justice Murphy stated that 'Seldom if ever in the history of this nation has there been such a concentrated and relentless crusade to deport an individual because he dared to exercise the freedom that belongs to him as a human being and that is guaranteed to him by the Constitution'. ${ }^{436}$ This thesis has tried to show just how accurate his assessment was.

The ongoing struggle of conservative surveillance operatives against organised labour is the thick narrative thread that binds the history of surveillance in California between 1918 and 1939. This thesis began with an exploration of how the 1919 Criminal Syndicalism Law granted law enforcement in California the mandate to crackdown on the IWW, a mandate that was later extended to break the back of organised labour wherever it showed its head. This was particularly the case in Los Angeles, where the Better America Federation, the Los Angeles Times, and the overzealous anti-unionism of the LAPD helped to forge a pro-business utopia. By 1925 the Criminal Syndicalism law had been successfully used to crush the IWW in California, effectively dismantling the largest drive to unionise 'open shop' Los Angeles then attempted. After recognising the implications of the federal government's withdrawal from countersubversive activities in 1924 the BAF and the LAPD Red Squad established the beginnings of a surveillance network, both collecting and archiving documents in their files. For the remainder of that decade, Hynes and other operatives continued building their organisations, pausing occasionally to lend their files and expertise to trials and other public exposures of the information they had collected. They were aided in this by the Los Angeles Times, who liked to remind readers that all the wealth of the 1920s was only possible because of the open shop.

During the 1930s the network grew in sophistication, membership, and their range of targets, connecting disparate anti-radical impulses into a semi-coordinated political and surveillance apparatus to resist the New Deal, its progeny and representatives. As the

\footnotetext{
436 Justice Murphy quoted in Dan Kanstroom, Deportation Nation: Outsiders in American History, (Cambridge: Harvard University Press, 2007), p. 199.
} 
economic, social and demographic pressures of the depression challenged their grip on power, network representatives used surveillance to redefine their environment, repeatedly demonstrating an ability to provide the evidentiary basis for the maintenance of a useful state of fear in California. The threat of communism, it has been shown, was then used to discredit civil libertarians, the labour movement, pacifists, the Democratic Party and the New Deal, all with some level of success. Though they had faced down repeated challenges from the labour movement and its communist firebrands, the network was less successful in the later years of the 1930s, partly because their opponents were beginning to adopt the same tactics. When the public campaign to deport Bridges finally came to trial, members of the surveillance network were unprepared for the same tactics to be used against them-suggesting that the network's repeated use of surveillance to expose political conspiracies primed their opponents to begin doing so themselves. While it is a study of surveillance, repression, and exposure, it is also a study of resistance to these related processes, and of those Californians who saw through the network's subterfuge.

Ultimately, the network's categories of suspicion, motivations, tactics, personnel, and documents were enshrined within an institutional format through their close cooperation with the Dies Committee well before the official start of Cold War anti-communism in 1947. Since that committee in turn laid the national foundations of the anti-communist movement of the late 1940s and early 1950s, their influence continued into the McCarthy era and beyond. In that era the anti-communist activists who inherited the Californian legacy had the resources and legislative power to go after radicals to an extent not seen since the first few years of the Criminal Syndicalism Bill. Similarly, dossiers and surveillance information collected during the interwar period would form the basis of many post-WWII accusations of communist sympathy during the second red scare period, both in California and nationally. Likewise the networks and alliances built up during this period, both intra-state and national, would similarly help mobilize right-wing activists during the 1950s against a broad range of leftist politics. Hollywood film workers would be blacklisted on the basis of their new deal era political sympathies, whether out of solidarity with Spanish Republicans or as a consequence of allowing Communists to represent their unions. Some of the same individuals who had been sharing information on Hollywood in the 1930s would find new employment working for 
HUAC, or return to private organisations such as the American Legion where picketing redlinked films became an effective tool of anti-communist activism.

As this suggests, the related processes of repression, surveillance, and exposure remained favoured tools of American political activism long after they were developed and applied in California between 1918 and 1939. 


\section{APPENDIX}

\section{Text of the California Criminal Syndicalism Law}

(An act defining criminal syndicalism and sabotage, proscribing certain acts and methods in connection therewith and in pursuance thereof and providing penalties and punishments therefore.)

(Approved April 30, 1919. In effect immediately)

The people of the state of California do enact as follows:

Sect. 1. The term 'criminal syndicalism' as used in this act is hereby defined as any doctrine or precept advocating, teaching or aiding and abetting the commission of crime, sabotage (which word is hereby defined as meaning wilful and malicious physical damage or injury to physical property), or unlawful acts of force and violence or unlawful methods of terrorism as a means of accomplishing a change in industrial ownership or control, or affecting any political change.

Sect. 2. Any person who:

1. By spoken or written words or personal conduct advocates, teaches or aids and abets criminal syndicalism or the duty, necessity or propriety of committing crime, sabotage, violence or any unlawful methods of terrorism as a means of accomplishing a change in industrial ownership or control; or

2. Wilfully and deliberately by spoken or written words justifies or attempts to justify criminal syndicalism or the commission or attempt to commit crime, sabotage, violence or unlawful methods of terrorism with intent to approve, advocate or further the doctrine of criminal syndicalism; or

3. Prints, publishes, edits, issues or circulates or publicly displays any book, paper, pamphlet, document, poster or written or printed matter in any other form, containing or carrying written or printed advocacy, teaching or aid and abetment of, or advising, criminal syndicalism; or 
4. Organizes or assist in organizing, or is or knowingly becomes a member of, any organization, society, group or assemblage or persons organized or assembled to advocate, teach or aid and abet criminal syndicalism; or

5. Wilfully by personal act or conduct, practices or commits any act advised, or advocated, taught or aided and abetted by the doctrine or precept of criminal syndicalism, with intent to accomplish a change in industrial ownership or control, or effecting any political change;

Is guilty of a felony and punishable by imprisonment in the state prison not less than one nor more than fourteen years.

Sect. 3 If for any reason any section, clause or provision of this act shall by any court be held unconstitutional than the legislature hereby declares that, irrespective of the unconstitutionality so determined, of such section, clause or provision, it would have enacted and made the law of this state all other sections, clauses and provisions of this act.

Sect. 4. Inasmuch as this act concerns and is necessary to the immediate preservation of the public peace and safety, for the reason that at the present time large numbers of persons are going from place to place in this state advocating, teaching and practicing criminal syndicalism, this act shall take effect upon approval by the governor. ${ }^{437}$

437 Woodrow C. Whitten, 'Criminal Syndicalism and the Law in California: 1919-1927,' Transactions of the American Philosophical Society, Vo.59, No.2 (January 1, 1969), p.65. 


\section{BIBLIOGRAPHY}

\section{Archival Primary Source Collections}

California Surveillance Collection, Labor Archives and Research Center, San Francisco State University.

Campaign 1962, Richard Nixon Presidential Library and Museum, Yorba Linda, California.

Norman Leonard Papers, Labor Archives and Research Center, San Francisco State University.

Records of the Special Committee on Un-American Activities, 1938-1944, National Archives and Records Administration, Washington, D.C.

The John Randolph Haynes Papers, 1890-1937, Young (Charles E.) Research Library, UCLA Special Collections, University of California, Los Angeles:

The Margaret Ann Kerr Papers, Hoover Institution Archives, Stanford University.

The Ralph H. Van Deman Papers, 1929-1952, Senate Internal Security Subcommittee Special Collections, National Archives and Records Administration, Washington, D.C.

The Ralph H. Van Deman Papers, Hoover Institution Archives, Stanford University.

Ralph Henry Van Deman, (FBI-FOIA files), FBI files HQ65-1242, 94-37516.

Vesta Muehleisen Papers, San Diego History Center Document Collection, San Diego. 


\section{Published Primary Sources}

Full access to the Los Angeles Times and New York Times provided through ProQuest Historical Newspapers, www.proquest.com.

Committee on Education and Labor, Subcommittee Investigating Violations of Free Speech and the Rights of Labor. Hearings before a Subcommittee of the Committee on Education and Labor, Washington, D.C: G.P.O, 1940.

Special Committee Investigating Communist Activities in the United States. Investigation of communist propaganda. Hearings before a Committee to Investigate Communist Activities in the United States, Washington, D.C.: GPO, 1930.

Special Committee on Un-American Activities. Hearings to Investigate Un-American Propaganda Activities in the United States, Washington, D.C: G.P.O., 1939.

Sinclair, Upton. The brass check, a study of American journalism, Pasadena, Calif.: The author, 1920.

- - - The goose-step : a study of American education, Pasadena, Calif.: The author, 1923.

Weber, Ralph (ed.), The Final Memoranda: Major General Ralph H. Van Deman, USA Ret., 18651952, Wilmington: SR Books, 1988. 


\section{Secondary Sources}

Almanzar, Nelson A. Pichado and Brian W. Kulik. American Fascism and the New Deal: The Associated Farmers of California and the Pro-Industrial Movement. Lanham: Lexington Books, 2013.

Auerbach, Jerold S. 'The La Follette Committee: Labor and Civil Liberties in the New Deal'. The Journal of American History Vol. 51, No. 3, December 1, 1964, pp. 435-459.

Avrich, Paul. The Haymarket Tragedy. Princeton: Princeton University Press, 1984.

Bell, Jonathan. California Crucible: the forging of modern American liberalism. Philadelphia: University of Pennsylvania Press, 2012

Boyarsky, Bill, and Peter Jones. Inventing L.A.: the Chandlers and Their Times. Santa Monica: Angel City Press, 2009.

Boyarsky, Bill. Los Angeles: City of Dreams. Memphis: Towery Publishing, 1999.

Brennan, Mary C. Wives, Mothers, and the Red Menace: Conservative Women and the Crusade against Communism. Boulder: University Press of Colorado, 2008.

Brinkley, Alan. 'The problem of American Conservatism'. The American Historical Review, Vol. 99, No. 2, 1994, pp. 409-429

Buckley, William F. The Committee and Its Critics; a Calm Review of the House Committee on UnAmerican Activities. New York: Putnam, 1962.

Capozzola, Christopher. Uncle Sam Wants You: World War I and the Making of the Modern American Citizen. New York: Oxford University Press, 2008.

Cherny, Robert W. 'The Making of a Labor Radical: Harry Bridges, 1901-1934'. Pacific Historical Review, Vol. 64, No. 3, August 1995, pp. 363-388.

- - - 'Prelude to the Popular Front: The Communist Party in California, 1931-1935'. American Communist History, Vol. 1, No. 1, 2002, pp. 5-42. 
Churchill, Ward. 'From the Pinkertons to the PATRIOT Act: The Trajectory of Political Policing in the United States, 1870 to the Present'. CR: The New Centennial Review Vol. 4, No. 1, 2004, pp. 1-72.

Cohen, Michael. 'The Ku Klux Government: Vigilantism, Lynching, and the Repression of the IWW'. Journal for the Study of Radicalism, Vol. 1, No. 1, 2007, pp. 31-56.

Critchlow, Donald T. When Hollywood Was Right: How Movie Stars, Studio Moguls and Big Business Remade American Politics. New York: Cambridge University Press, 2013.

Critser, Greg. 'The Making of a Cultural Rebel: Carey McWilliams, 1924-1930'. Pacific Historical Review, No. 55, 1986, pp. 226-255.

Cross, Ira B. A History of the Labor Movement in California. Berkeley: University of California Press, 1935.

Daniel, Cletus E. Bitter Harvest: A History of California Farmworkers, 1870-1941. Ithaca, N.Y.: Cornell University Press, 1981.

Davis, Mike. City of Quartz: Excavating the Future of Los Angeles. New York: Vintage Books, 1992.

- - - 'Sunshine and the Open Shop: Ford and Darwin in 1920s Los Angeles,' in Tom Sitton and William Deverell (ed.) Metropolis in the Making: Los Angeles in the 1920s. Berkeley: University of California Press, 2001.

Deverell, William and Greg Hise. Land of Sunshine: an Environmental History of Metropolitan Los Angeles. Pittsburgh: University of Pittsburgh Press, 2005.

Donalson, Daniel G. “A Convenient Engine of Oppression:' Personal Uses of the Espionage and Sedition Acts of World War I'. Unpublished Ph.D. Diss., University of Houston, 2009.

Donner, Frank J. The Age of Surveillance: the Aims and Methods of America's Political Intelligence System. New York: Knopf, 1980.

- - . Protectors of Privilege: Red Squads and Police Repression in Urban America, Berkeley: University of California Press, 1992.

- - - The un-Americans. New York: Ballantine Books, 1961.

Eisloeffel, Paul. 'The Cold War and Harry Steinmetz: A Case of Loyalty and Legislation'. The Journal of San Diego History, Vol. 35, No. 4, 1989. 
Fine, Sidney. Without Blare of Trumpets: Walter Drew, the National Erectors' Association, and the Open Shop Movement, 1903-57. Ann Arbor: University of Michigan Press, 1995.

Fogelson, Robert M. The Fragmented Metropolis: Los Angeles, 1850-1930. Cambridge: Harvard University Press, 1967.

Foner, Philip Sheldon. History of the Labor Movement in the United States. 3, The Policies and Practices of the American Federation of Labor. Vol. 3. New York: Internat. Publ., 1981.

- - - History of the Labor Movement in the United States. 4, The Industrial Workers of the World: 1905-1917. Vol. 4. New York: Internat. Publ., 1973.

- - - History of the Labor Movement in the United States. 5, The AFL in the Progressive Era, 19101915. Vol. 5. New York: Internat. Publ., 1980.

- - . History of the Labor Movement in the United States. 6, On the Eve of America's Entrance into World War I, 1915-1916. Vol. 6. New York: International Publishers, 1982.

- - - History of the Labor Movement in the United States. 7, Labor and World War I, 1914-1918. Vol. 7. New York: International Publishers, 1987.

Foucault, Michel. Discipline and punish: the birth of the prison. New York: Pantheon Books, 1977.

Fried, Richard M. Nightmare in Red: The McCarthy Era in Perspective. New York: Oxford University Press, 1990.

Fronc, Jennifer. New York Undercover: Private Surveillance in the Progressive Era. Chicago: University of Chicago Press, 2009.

Frost, Jennifer. 'Dissent and Consent in the 'Good War': Hedda Hopper, Hollywood Gossip, and World War II Isolationism'. Film History, Vol.22, No. 2, June 2010, pp. 170-181.

Geary, Daniel. 'Carey McWilliams and Antifascism'. The Journal of American History, Vol. 90, No. 3, December 2003, pp. 912-934.

Gottlieb, Robert. A Life of Its Own: the Politics and Power of Water. San Diego: Harcourt Brace Jovanovich, 1988.

Gottlieb, Robert, Mark Vallianatos, Regina Freer, and Peter Dreier. The Next Los Angeles: The Struggle for a Livable City. Berkeley: University of California Press, 2005. 
Greenstein, Paul, Nigey Lennon, and Lionel Rolfe. Bread \& Hyacinths : the Rise and Fall of Utopian Los Angeles. Los Angeles: California Classic Books, 1992.

Gumprecht, Blake. The Los Angeles River: Its Life, Death, and Possible Rebirth. Baltimore: Johns Hopkins University, 1999.

Haggerty, Kevin and Richard V. Ericson, 'The Surveillant Assemblage'. The British Journal of Sociology, Vol. 51, No. 4, 2000, pp. 605-622.

Halberstam, David. The Powers That Be. Urbana: University of Illinois Press, 2000.

Hart, Jack. "The Information Empire: A history of the "Los Angeles Times" from the Era of Personal Journalism to the Advent of the Multi-Media Communications Corporation', Unpublished Ph.D. Diss., University of Madison-Wisconsin, 1975.

Heale, M. J. ‘Red Scare Politics: California's Campaign against Un-American Activities, 19401970'. Journal of American Studies, Vol. 20, No. 1, 1986, pp. 5-32.

-- . McCarthy's Americans: Red Scare Politics in State and Nation, 1935-1965. Athens: University of Georgia Press, 1998.

Healey, Dorothy, and Maurice Isserman. California Red: a Life in the American Communist Party. Urbana, Ill.: University of Illinois Press, 1993.

Hoffman, Abraham. Vision or Villainy: Origins of the Owens Valley-Los Angeles Water Controversy. College Station: Texas A \& M University Press, 1981.

Hoffman, Abraham. 'Joseph Barlow Lippincott and the Owens Valley Controversy'. Southern California Quarterly, Vol. 54, No. 3, 1972, pp. 239-254.

Hurewitz, Daniel. Bohemian Los Angeles and the Making of Modern Politics. Berkeley: University of California Press, 2007.

Jensen, Joan M. Army Surveillance in America, 1775-1980. New Haven: Yale University Press, 1991.

Johnson, Daniel. "No make-believe Class Struggle': The Socialist Municipal Campaign in Los Angeles, 1911'. Labor History, Vol. 41, No. 1, 2000, pp. 25-45.

Kahrl, William L. Water and Power : the Controversy over Los Angeles' Water Supply in the Owens Valley. Berkeley: University of California Press, 1981. 
Kanstroom, Dan. Deportation Nation: Outsiders in American History. Cambridge: Harvard University Press, 2007.

Kimeldorf, Howard. Reds or rackets?: The making of Radical and Conservative Unions on the Waterfront. Berkeley: University of California Press, 1992.

Kraft, James P. 'The Fall of Job Harriman's Socialist Party: Violence, Gender, and Politics in Los Angeles, 1911'. Southern California Quarterly, Vol. 70, No. 1, Spring 1988, pp. 43-68.

Kramer, Alisa Sarah. 'William H. Parker and the Thin Blue Line: Politics, Public Relations and Policing in Postwar Los Angeles'. Unpublished Ph.D. Diss., The American University, 2007.

Laslett, John. Sunshine was never enough, Los Angeles Workers, 1880-2010. Los Angeles: University of California Press, 2012.

Layton, Edwin. 'The Better America Federation: A Case Study of Superpatriotism'. Pacific Historical Review, Vol. 30, No. 2, May 1, 1961, pp. 137-147.

Lichtman, Robert M. and Ronald D. Cohen. Deadly Farce: Harvey Matusow and the Informer System in the McCarthy Era. Urbana: University of Illinois Press, 2004.

Lichtman, Robert. 'Louis Budenz, the FBI, and the "List of 400 Concealed Communists": An Extended Tale of McCarthy-era Informing'. American Communist History, Vol. 3, No. 1, June 2004, pp. 25-54.

- - - 'J. B. Matthews and the 'Counter-subversives': Names as a Political and Financial Resource in the McCarthy Era'. American Communist History, Vol. 5, No. 1, June 2006, pp.136.

Lingeman, Richard. 'Domestic Containment: The Downfall of Postwar Idealism and Left Dissent, 1945-1950' in Mark Carnes (ed.) The Columbia History of post-World War II America. New York: Columbia University Press, 2007.

Luff, Jennifer D. 'Judas Exposed: Labor Spies in the United States'. Unpublished Ph.D. Diss., The College of William and Mary, 2005.

Marx, Gary T. Undercover : Police Surveillance in America. Berkeley: University of California Press, 1988. 
McLellan, Scott Allen. 'Policing the Red Scare: The Los Angeles Police Department's Red Squad and the Repression of Labor Activism in Los Angeles, 1900-1940'. Unpublished Ph.D. Diss., University of California, Irvine, 2011.

McCoy, Alfred. Policing America's empire: the United States, the Philippines, and the rise of the surveillance state. Madison: University of Wisconsin Press, 2009.

McDougal, Dennis. Privileged Son: Otis Chandler and the Rise and Fall of the L.A. Times Dynasty. Cambridge, Mass.: Perseus Pub., 2001.

McGirr, Lisa. Suburban Warriors : the Origins of the New American Right. Princeton, N.J.: Princeton University Press, 2001.

McWilliams, Carey, and Erskine Caldwell. Southern California Country: an Island on the Land. New York: Duell, Sloan \& Pearce, 1946.

- - - Factories in the Field: The Story of Migratory Farm Labor in California. Boston: Little, Brown, 1939.

Messer-Kruse, Timothy. The Haymarket Conspiracy: Transatlantic Anarchist Networks. Urbana: University of Illinois Press, 2012.

Miller, Richard Connelly. 'Otis and His Times: The Career of Harrison Gray Otis'. Unpublished Ph.D. Diss., University of California, 1961.

Mitchell, Greg. Tricky Dick and the Pink Lady: Richard Nixon Vs. Helen Gahagan Douglas-- Sexual Politics and the Red Scare, 1950. New York: Random House, 1997.

Morn, Frank. 'The Eye That Never Sleeps': a History of the Pinkerton National Detective Agency. Bloomington: Indiana University Press, 1982.

Muelen, Jacob Vander 'West Coast Labor and the Military Aircraft Industry'. Pacific Northwest Quarterly, Vol. 88, No. 2, Spring 1997, pp. 82-92.

Mulholland, Catherine. William Mulholland and the Rise of Los Angeles. Berkeley: University of California Press, 2002.

Murphy, Paul. 'Sources and nature of intolerance in the 1920s'. The Journal of American History, Vol. 51, No. 1, June 1964, pp. 60-76.

Murphy, Walter. Elements of Judicial Strategy. Chicago: University of Chicago Press, 1964. 
Navasky, Victor S. Naming Names. New York: Viking Press, 1980.

Nickerson, Michelle M. 'Domestic Threats: Women, Gender and Conservatism in Cold War Los Angeles, 1945-1966'. Unpublished Ph.D. Diss., Yale University, 2003.

Nicolaides, Becky. My Blue Heaven: Life and Politics in the working-class suburbs of Los Angeles, 1920-1965. Chicago: University of Chicago Press, 2002.

O'Reilly, Kenneth. Hoover and the un-Americans: the FBI, HUAC, and the Red Menace. Philadelphia: Temple University Press, 1983.

Parmar, Inderjeet. 'Conceptualising the state-private network in American foreign policy', in Helen Laville \& Hugh Wilford (eds.) The US Government, Citizen Groups and the Cold War: The state-private network. New York: Routledge, 2006.

Perlstein, Rick. Before the Storm: Barry Goldwater and the Unmaking of the American Consensus. New York: Hill and Wang, 2001.

Power, Richard Gid. Not Without Honor: The History of American anticommunism. New York: Free Press, 1995.

Preston, William. Aliens and Dissenters: Federal Suppression of Radicals, 1903-1933. Cambridge, Mass.: Harvard University Press, 1963.

Pulido, Laura. Black, Brown, Yellow, and Left: Radical Activism in Los Angeles. Berkeley: University of California Press, 2006.

Richardson, Peter. American prophet the life $\mathcal{E}$ work of Carey McWilliams. Ann Arbor: University of Michigan Press, 2005.

Roderick, Kevin. The San Fernando Valley: America's Suburb. Los Angeles: Los Angeles Times Books, 2001.

Rymph, Catherine E. Republican Women: Feminism and Conservatism from Suffrage Through the Rise of the New Right. Chapel Hill: University of North Carolina Press, 2006.

Sbardellati, John. J. Edgar Hoover goes to the movies: the FBI and the origins of Hollywood's Cold War. Ithaca: Cornell University Press, 2012.

Schmidt, Regin. Red Scare: FBI and the Origins of Anticommunism in the United States, 1919-1943. Copenhagen: Museum Tusculanum Press, 2000. 
Schrecker, Ellen. Many Are the Crimes : McCarthyism in America. Boston: Little, Brown, 1998.

- - . 'McCarthyism's Ghosts: Anticommunism and American Labor'. New Labor Forum, No. 4, April 1999, pp. 7-17.

Schultz, Bud and Ruth. It Did Happen Here: Recollections of Political Repression in America. Berkeley: University of California Press, 1989.

Schuparra, Kurt. Triumph of the Right: the Rise of the California Conservative Movement, 1945-1966. Armonk, N.Y.: M.E. Sharpe, 1998.

Schwartz, Stephen. From West to East: California and the Making of the American Mind. New York: Simon \& Schuster, 1998.

Scully, Leon F. Bombers, Bolsheviks, and Bootleggers : a Study in Constitutional Subversion. Houston, Texas: Publius Books, 2001.

Seldes, George. Lords of the Press. New York: J. Messner, Inc., 1938.

Sibley, Mulford Q. 'Ethics and the Professional Patriots'. Annals of the American Academy of Political and Social Science, No. 363, January 1, 1966, pp.126-136.

Sitton, Tom, and William Deverell. Metropolis in the Making: Los Angeles in the 1920s. Berkeley: University of California Press, 2001.

Sitton, Tom. John Randolph Haynes: California Progressive. Stanford: Stanford University Press, 1992.

Smith, Robert Michael. From Blackjacks to Briefcases : a History of Commercialized Strikebreaking and Unionbusting in the United States. Athens: Ohio University Press, 2003.

Staples, William G. The Culture of Surveillance: Discipline and Social Control in the United States. New York, NY: St. Martin's Press, 1997.

Starr, Kevin. Americans and the California Dream, 1850-1915. New York: Oxford University Press, 1973.

- - - Inventing the Dream: California Through the Progressive Era. New York: Oxford University Press, 1985. 
- - - Material Dreams: Southern California through the 1920s. New York: Oxford University Press, 1990.

---. Endangered Dreams: the Great Depression in California. New York: Oxford University Press, 1996.

- - - The Dream Endures: California Enters the 1940s. New York: Oxford University Press, 1997.

- - . Embattled Dreams: California in War and Peace, 1940-1950. New York: Oxford University Press, 2002.

- - . Golden Dreams: California in an Age of Abundance. 1950-1963. New York: Oxford University Press, 2009.

Steele, Richard. Free Speech in the good war. New York: St. Martin's Press, 1999.

Stevens, Errol Wayne. Radical L.A.: from Coxey's Army to the Watts Riots, 1894-1965. Norman: University of Oklahoma Press, 2009.

Storrs, Landon. The Second Red Scare and the unmaking of the New Deal left. Princeton: Princeton University Press, 2013.

Talbert, Roy. Negative Intelligence: the Army and the American Left, 1917-1941. Jackson, Miss.: University Press of Mississippi, 1991.

Theoharis, Athan G. Spying on Americans: Political Surveillance from Hoover to the Huston Plan. Philadelphia: Temple University Press, 1978.

- - - The FBI \& American Democracy: a Brief Critical History. Lawrence: University Press of Kansas, 2004.

Tygiel, Jules. The Great Los Angeles swindle: oil, stocks, and scandal during the Roaring Twenties. New York: Oxford University Press, 1994.

Van Valen, Nelson. "Cleaning Up The Harbor': The Suppression of the I.W.W. at San Pedro, 1922-1925'. Southern California Quarterly, Vol. 66, No. 2, 1984, pp. 147-172.

Vaughn, Robert. Only Victims; a Study of Show Business Blacklisting. New York: Putnam, 1972.

Wakstein, Allen M. 'The Origins of the Open-Shop Movement, 1919-1920'. The Journal of American History, Vol. 51, No. 3, December 1, 1964, pp. 460-475. 
Walton, John. Western Times and Water Wars : State, Culture, and Rebellion in California. Berkeley: University of California Press, 1992.

Ward, Estolv. Harry Bridges on Trial. New York: Modern Age Books, 1940.

Weiss, Robert P. ‘Private Detective Agencies and Labour Discipline in the United States, 18551946'. Historical Journal, Vol. 29, No. 1, 1986, pp. 87-107.

- - - ' 'From Cowboy Detectives to Soldiers of Fortune: Private Security Contracting and its contradictions on the New Frontiers of Capitalist Expansion'. Social Justice, Vol. 34, No. 34, 2007-8, pp. 1-19.

Williams, David. 'The Bureau of Investigation and its Critics, 1919-1921: The Origins of Federal Political Surveillance'. The Journal of American History, Vol. 68, No. 3, December 1981, pp. 560-579.

Wilson, Veronica A. 'Anticommunism, Millenarianism and the Challenges of Cold War Patriarchy: The Many Lives of FBI Informant Herbert Philbrick'. American Communist History, Vol. 8, No. 1, June 2009, pp. 73-102.

Woods, Joseph Gerald. 'The Progressives and the Police: Urban Reform and the Professionalization of the Los Angeles Police'. Unpublished Ph.D. Diss., University of California, Los Angeles, 1973.

Worster, Donald. Rivers of Empire: Water, Aridity, and the Growth of the American West. New York: Pantheon Books, 1985.

Zanger, Martin. 'Politics of Confrontation: Upton Sinclair and the Launching of the ACLU in Southern California'. Pacific Historical Review, Vol. 38, No. 4, November 1969, pp. 383-406. 